\title{
FRONTEIRA DE EFICIÊNCIA ECONÔMICA EM CONDIÇÕES DE RISCO: ANÁLISE DE SISTEMAS DE PRODUÇÃO FAMILIARES DA REGIĀO CENTRO-SUL DO PARANÁ
}

\author{
MARIA DO CARMO RAMOS FASIABEN \\ Engenheiro Agrônomo \\ Orientadora: $\operatorname{Prof}^{\mathrm{a}} \mathrm{D}^{\mathrm{ra}}$ MIRIAN RUMENOS PIEDADE BACCHI
}

Dissertação apresentada à Escola Superior de Agricultura "Luiz de Queiroz", Universidade de São Paulo, para obtenção do título de Mestre em Ciências, Área de Concentração: Economia Aplicada.

\author{
PIRACICABA \\ Estado de São Paulo - Brasil \\ Maio - 2002
}




\section{Dados Internacionais de Catalogação na Publicação (CIP) DIVISÃO DE BIBLIOTECA E DOCUMENTAÇÃO - ESALQ/USP}

\section{Fasiaben, Maria do Carmo Ramos}

Fronteira de eficiência econômica em condiçôes de risco: análise de sistemas de produção familiares da regiāo Centro-Sul do Paraná / Maria do Carmo Ramos Fasiaben. - Piracicaba, 2002.

$121 \mathrm{p}$.

Dissertação (mestrado) - - Escola Superior de Agricultura Luiz de Queiroz, 2002. Bibliografia.

1. Administração agrícola 2. Agricultura (Aspectos econômicos) 3. Agricultura familiar 4. Eficiência econômica 5. Politica agrícola 6. Produção agricola 7. Programação linear 8. Risco 9. Sistemas de produção I. Título

CDD 338.1 
A minha mãe, Trindad, e a meu pai, João (in memorian), pelo amor, dedicação e confiança. A meus irmãos, Manoel e Francisco, pelo apoio e incentivo. A minha filhinha Ana Elisa, minha melhor amiga. 


\section{AGRADECIMENTOS}

À professora Mirian Rumenos Piedade Bacchi, pela dedicação e competência na orientação do trabalho e, sobretudo, pela amizade e incentivo demonstrados em todos os momentos, que transcenderam a dimensão profissional e me ajudaram a superar os momentos difíceis.

Ao professor Fernando Curi Peres pela inestimável ajuda no processo de modelagem, pelas inúmeras sugestões e, sobretudo, pela paciência e presteza em elucidar um sem número de interrogações.

Aos professores Vania Di Addario Guimarães e Alexandre Lahoz Mendonça de Barros pelas sugestões e críticas, que enriqueceram o trabalho.

Aos professores Ruben Jacques Martins, Sérgio Roberto Postiglioni e Ademir de Lucas pela valiosa colaboração na aferição dos coeficientes técnicos empregados no estudo.

Aos professores e funcionários do Departamento de Economia, Administração e Sociologia da ESALQ/USP, que direta ou indiretamente colaboraram com a realização deste trabalho.

Ao Conselho Nacional de Desenvolvimento Científico e Tecnológico $(\mathrm{CNPq})$ e à Coordenação de Aperfeiçoamento de Pessoal de Ensino Superior (CAPES) pela bolsa de estudos 
Às instituições atuantes na área de estudos, que apoiaram a realização dos trabalhos de campo e prestaram relevantes informações: à Cooperativa de Crédito Solidário de Pitanga (CRESOL-Pitanga), na figura de seu presidente Sr. Mauro Marques; ao Sindicato de Trabalhadores Rurais de Boa Ventura de São Roque, na figura de seu presidente, Sr. Aroldo Ribeiro; ao Departamento de Agricultura e Desenvolvimento do município de Boa Ventura de São Roque, na figura de seu diretor, Sr. Gilberto Luiz dos Santos; à Cooperativa Agropecuária Mourãoense Ltda. de Boa Ventura de São Roque (COAMO); à Empresa de Assistência Técnica e Extensão Rural do Paraná (EMATER-PR) de Pitanga; à Secretaria Agropecuária Municipal de Pitanga e ao Instituto Agroflorestal de Turvo, na figura de seu coordenador Geraldo Schipper.

Aos engenheiros agrônomos e técnicos locais: Amilcar Afonso Marques, Clóvis Luiz Finatto, Cláudio Luiz Guimarães Marques, Deyse Aguiar Battistelli, Valdemir Machado Weber e João Kachoroski, e aos produtores: Augusto Kafassiak, Cláudio Latczuk, Teodoro Kafassiak, Benjamim da Silva, Pedro Miranda, João Santos da Silva, Carlos Febbes, Valdemiro Variza e Nelson Peres da Silva, pela grande contribuição na caracterização da agricultura regional.

Aos colegas de curso, pelo apoio e estímulo, em especial a Ariel Wilder, Cléa Rahal, Adriana Bussoni, Lucílio Alves, Alexandre Nicolella, Sílvio Ichihara, Julcemar Zilli e Marcos Hasegawa.

Agradeço, de forma muito especial, aos agricultores que participaram com atenção e paciência das entrevistas, recebendo-me com extrema cortesia em suas casas. Agradeço a acolhida carinhosa de Aroldo e Elisabethe e sua colaboração para o andamento da pesquisa de campo. Sem essas ajudas espontâneas este trabalho não teria sido realizado. 


\section{SUMÁRIO}

Página

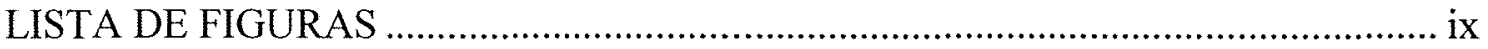

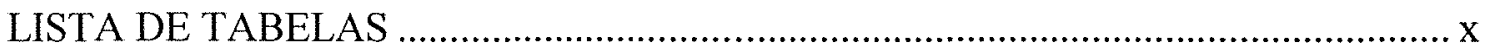

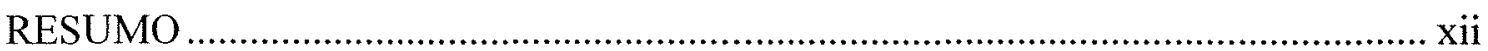

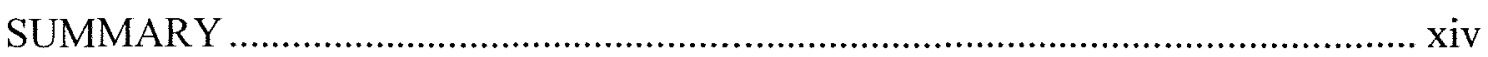

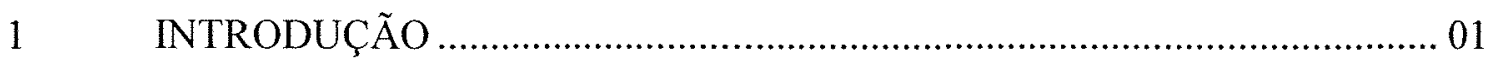

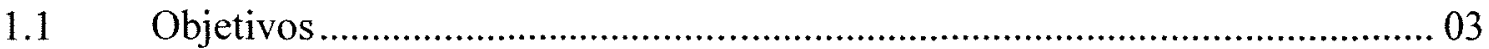

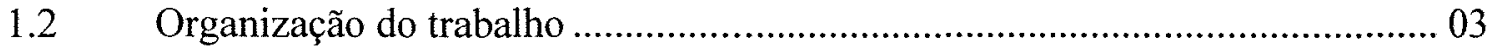

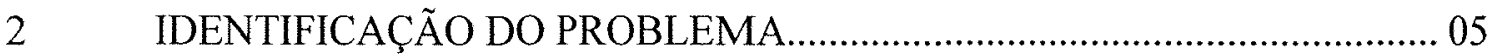

2.1 A agricultura familiar no Brasil segundo o censo de 1995/96 ........................ 06

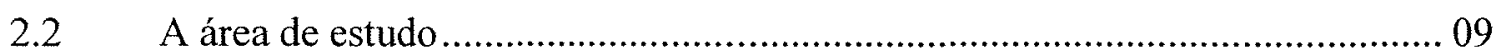

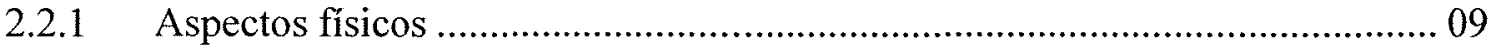

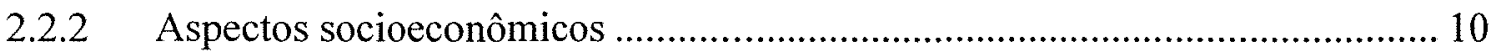

2.2.3 Instituições atuando junto à agricultura familiar............................................ 16

2.3 A problemática da restrição de recursos e a melhoria da eficiência ................. 18

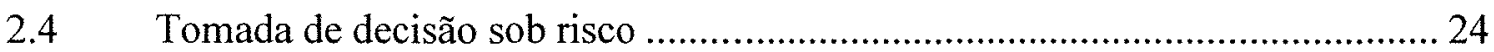

3 USO DA PROGRAMAÇÃO MATEMÁTICA NA

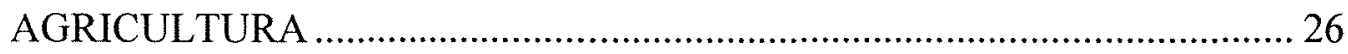

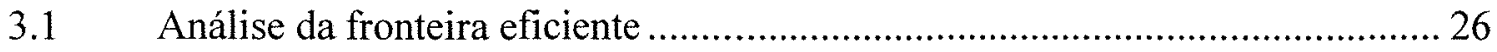

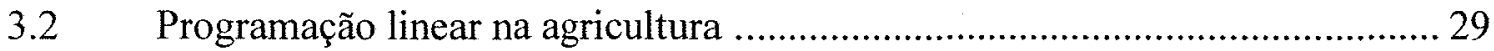

3.3 Especificação do modelo MOTAD ............................................................. 31

4 PROCEDIMENTOS PARA A ESCOLHA DE SISTEMAS DE PRODUÇÃO PARA MODELAGEM ........................................................ 36

4.1 Fundamentos sobre tipificação de produtores rurais..................................... 37 
4.2 Critérios de diferenciação de produtores ………............................................. 40

4.2.1 Diferenciação segundo parecer dos agricultores......................................... 41

4.2.2 Diferenciação segundo parecer dos técnicos................................................. 43

4.3 Tipificação de produtores por amostragem de estabelecimentos.....................47

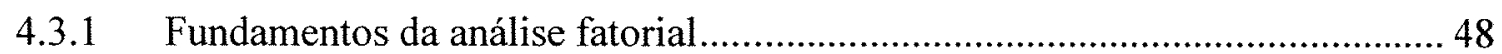

4.3.2 Tipologia de produtores de Boa Ventura de São Roque-PR ............................ 52

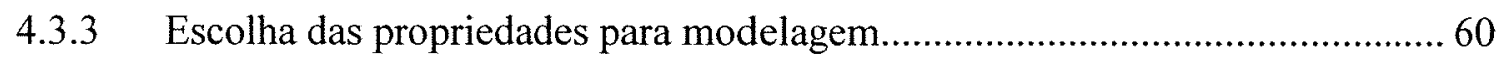

5 METODOLOGIA PARA MODELAGEM DE SISTEMAS DE

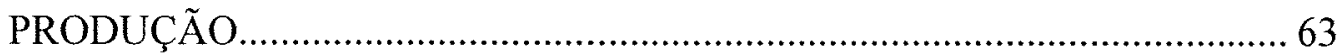

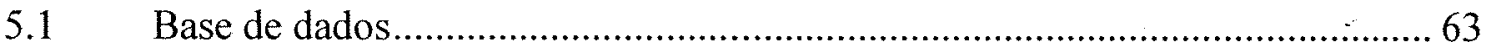

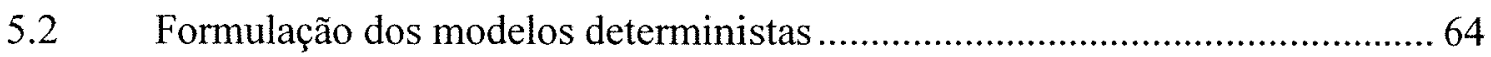

5.3 Formulação dos modelos em condições de risco ...........................................6 65

5.4 Determinação da fronteira eficiente e do coeficiente de aversão ao

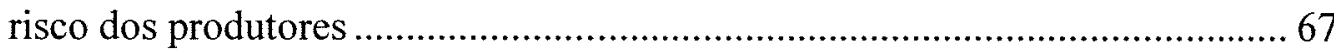

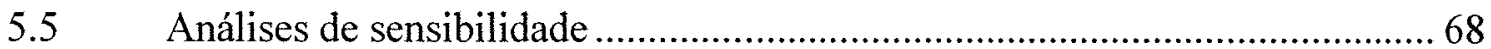

6 RESULTADOS E DISCUSSÃO DA MODELAGEM DE SISTEMAS DE PRODUÇÃO ................................................................ 70

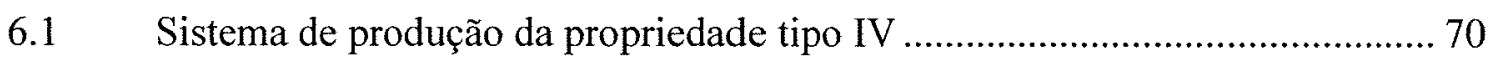

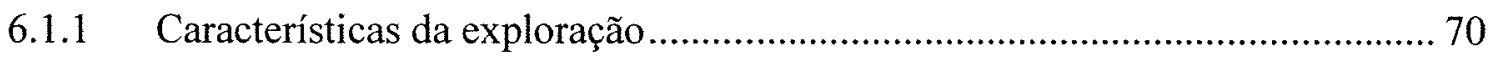

6.1.2 Modelo determinista para a propriedade tipo IV: atividades, restrições, função objetivo e análises de sensibilidade ................................... 72

6.1.3 Modelo com incorporação do risco para a propriedade tipo IV ....................... 83

6.1.4 Localização do sistema atual na fronteira eficiente e coeficiente de aversão ao risco da propriedade tipo IV

6.1.5 Diversificação de atividades como forma de redução do risco para a propriedade tipo IV

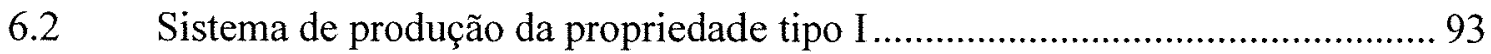

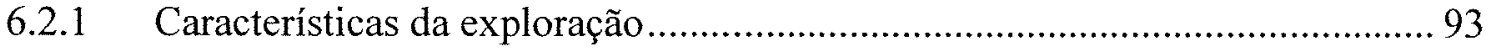

6.2.2 Modelo determinista para a propriedade tipo I: atividades, restrições, função objetivo e análises de sensibilidade 
6.2.3 Modelo com incorporação do risco para a propriedade tipo I....................... 103

6.2.4 Localização do sistema atual na fronteira eficiente e coeficiente de aversão ao risco da propriedade tipo I.................................................... 106

6.2.5 Diversificação de atividades como forma de redução do risco para a propriedade tipo I .............................................................................. 108

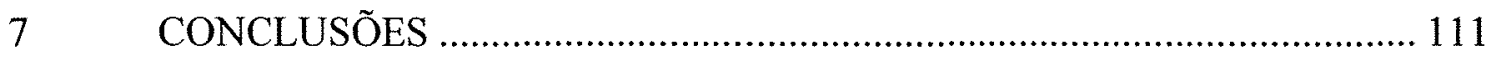

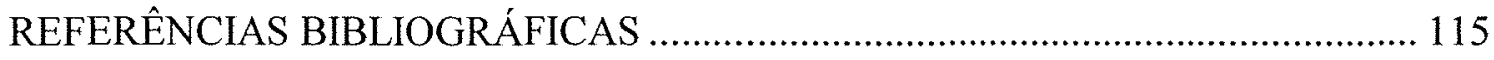




\section{LISTA DE FIGURAS}

Página

1 A fronteira E-V como plano ótimo da empresa agrícola...................................... 27

2 Dispersão das propriedades segundo fator 1 (área e capital) e fator 2

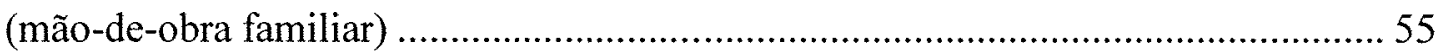

3 Fronteira eficiente da propriedade tipo IV, com contratação de mão-deobra. 90

4 Fronteira eficiente da propriedade tipo IV, sem contratação de mão-deobra

5 Fronteira eficiente da propriedade tipo I, com venda de mão-de-obra..................... 107

6 Fronteira eficiente da propriedade tipo I, sem venda de mão-de-obra ...................... 108 


\section{LISTA DE TABELAS}

Página

1 Porcentagem de estabelecimentos e participação no VBT dos principais produtos dos municípios de Boa Ventura de São Roque e Pitanga - PR, no universo da agricultura familiar, safra 95/96

2 Renda agropecuária média por categoria familiares ( $\mathrm{R}$ /ano) 14

3 Principais fatores de diferenciação de estabelecimentos agrícolas, segundo agricultores e técnicos 46

4 Raízes características (Eigenvalue), porcentagem da variância e porcentagem da variância acumulada. Tipologia de produtores de Boa Ventura de São Roque, Paraná

5 Coeficientes de correlação, comunalidades e porcentagem da variância explicada por cada fator após rotação (método Varimax). Tipologia de produtores de Boa Ventura de São Roque, Paraná 54

6 Médias e desvios padrões de variáveis de caracterização dos quatro tipos de produtores de Boa Ventura de São Roque, PR

7 Composição de atividades do sistema atual e dos modelos deterministas para a propriedade tipo IV

8 Restrições atuantes, preço-sombra e intervalos de RHS para manutenção do status para a propriedade tipo IV, sem contratação de mão-de-obra

9 Análise de sensibilidade de alguns coeficientes da função objetivo da propriedade tipo IV

10 Resultados do modelo MOTAD para a propriedade tipo IV, considerando a possibilidade de contratação de mão-de-obra externa 
11 Resultados do modelo MOTAD para a propriedade tipo IV, sem contratação de mão de-obra externa

12 Matriz de correlações entre as atividades produtivas da propriedade tipo IV 92

13 Composição de atividades do sistema atual e dos modelos deterministas para a propriedade tipo I

14 Restrições atuantes, preço-sombra e intervalos de RHS para manutenção do status para a propriedade tipo I, sem contratação de mão-de-obra

15 Análise de sensibilidade dos coeficientes da função objetivo da propriedade tipo I, com venda de mão de obra equivalente a $21,67 \mathrm{DH}$

16 Resultados do modelo MOTAD para a propriedade tipo I, com venda de mão-de-obra

17 Resultados do modelo MOTAD para a propriedade tipo I, sem venda de mão-de-obra

18 Matriz de correlações entre as atividades produtivas da propriedade tipo I. 


\title{
FRONTEIRA DE EFICIÊNCIA ECONÔMICA EM CONDIÇÕES DE RISCO: ANÁLISE DE SISTEMAS DE PRODUÇÃO FAMILIARES DA REGIÃO CENTRO-SUL DO PARANÁ
}

\author{
Autora: MARIA DO CARMO RAMOS FASIABEN \\ Orientadora: Prof $^{a} D^{\text {ra }}$ MIRIAN RUMENOS PIEDADE BACCHI
}

\section{RESUMO}

É muito grande a diferença na renda recebida pelos produtores agropecuários no Brasil. Isto se observa mesmo quando se trata do universo da agricultura familiar. $\mathrm{Na}$ Região Sul, onde se desenvolveu este trabalho, 51,4\% dos agricultores familiares recebem renda anual inferior a $R \$ 3.000,00$, enquanto $1,8 \%$ têm renda superior a $\mathrm{R} \$ 27.500,00$. O presente trabalho foi conduzido no município de Boa Ventura de São Roque, na região Centro-Sul do Paraná. Para conhecer a diversidade dos sistemas de produção agropecuários praticados no município elaborou-se uma tipologia empregando-se a análise fatorial por componentes principais a uma amostra de 34 estabelecimentos agrícolas, que foi validada por agricultores e técnicos locais. A tipificação de produtores permitiu a descrição de quatro grupos de estabelecimentos na área de estudos e embasou a escolha de propriedades para análise do processo de tomada de decisão, em condições de risco, de dois tipos extremos de sistemas de produção (um minifundista e um grande produtor), ambos de natureza familiar e que, apesar da grande diferença de dotação de recursos produtivos, têm a soja como a principal atividade 
produtiva. A Programação Linear foi utilizada para modelar os sistemas de produção das unidades familiares consideradas na análise e o modelo MOTAD ${ }^{1}$ foi empregado para a construção da fronteira eficiente, que representa o risco envolvido para a obtenção de determinados níveis de margem bruta. Contrariamente ao esperado, os resultados mostram que o pequeno produtor apresentou taxa de aversão ao risco menor que a do grande, dada a combinação de atividades de seu sistema atual de produção. Os resultados indicam que políticas públicas inerentes à melhoria da infraestrutura regional, assistência técnica, crédito rural, comercialização e geração de empregos são fundamentais para aumentar a rentabilidade das unidades produtoras familiares e possibilitar a permanência dos pequenos agricultores no meio rural.

\footnotetext{
${ }^{1}$ Minimização do desvio absoluto total.
} 


\title{
ECONOMIC EFFICIENCY FRONTIER UNDER RISK CONDITIONS: ANALYSIS OF FAMILY PRODUCTIONS SYSTEMS IN THE MID-SOUTH AREA OF PARANA
}

\author{
Author: MARIA DO CARMO RAMOS FASIABEN \\ Adviser: Prof ${ }^{a} D^{\text {ra }}$ MIRIAN RUMENOS PIEDADE BACCHI
}

\section{SUMMARY}

There is a great disparity in the income of agriculture producers in Brazil. This is also observed in a family farming universe. In the South, where the present research was developed, $51.4 \%$ of the family farmers earn an annual income of less than $R \$ 3,000.00$, whereas $1.8 \%$ earn over $R \$ 27,500.00$. The present work was conducted in the town of Boa Ventura de São Roque in the mid-south of the state of Parana. In order to get acquainted with the agricultural production systems of the town, a typology was elaborated, applying the principal component analysis, which was validated by local farmers and technicians, to a sample of 34 farms. The producers typification resulted in the description of four groups of farms in the study area and provided the basis for the choice of properties for the analysis of the decision-taking process, under risk conditions, of two ends of the production system (a small farm owner and a great producer). Both were family businesses, which had soy as their main production activity, despite the great difference in production resources. The Linear Programming was used to model the production systems of the family units considered in the analysis. The MOTAD model was used for the construction of the efficient frontier, which represents 
the risk involved for obtaining certain levels of gross margin. Contrarily to what was expected, the results show that the rate of risk aversion for smaller producers was lower than that for larger producers, given the combination of activities of their current production system. The results indicate that public policies, which are inherent for the improvement of the regional infrastructure, technical assistance, farmer loans, commercialization and employment generation, are fundamental to increase the profitability of the family producing units and allow small farmers to remain in the agricultural business. 


\section{INTRODUÇÃO}

No Brasil, o processo de transformação da agricultura aumentou a distância entre os estabelecimentos agropecuários no que diz respeito ao padrão tecnológico, ao padrão educacional e ao padrão econômico dos produtores. Observam-se níveis muito desiguais de renda, fruto das profundas diferenças na rentabilidade dos empreendimentos e no acesso aos benefícios do desenvolvimento. Se em nível nacional essas diferenças são notórias, vale ressaltar que elas muitas vezes se apresentam mesmo quando se tratam de regiões edafoclimáticas homogêneas. Também se observa uma importante diferenciação quando se toma especificamente o caso da agricultura familiar no país.

Os dados do censo agropecuário de 1995/96 mostram a importância da agricultura familiar no Brasil, permitindo a análise de seus contrastes. Os estabelecimentos classificados como de agricultura familiar representam $85,2 \%$ do total dos estabelecimentos agrícolas, ocupam $30,5 \%$ da área total e são responsáveis por $37,9 \%$ do Valor Bruto da Produção (VBP), recebendo 25,3\% do financiamento destinado à agricultura. Ela mantém $76,9 \%$ do pessoal ocupado na agricultura e é a maior responsável pela produção nacional de leite, suínos, feijão, mandioca, cebola, fumo, milho, trigo, banana, entre outras. No tocante à renda, $0,8 \%$ dos estabelecimentos familiares tem renda superior a $\mathrm{R} \$ 27.500,00 / \mathrm{ano} ; 6,3 \%$ têm renda entre $\mathrm{R} \$ 8.000,00 \mathrm{e}$ $\mathrm{R} \$ 27.500,00 ; 15,7 \%$ renda entre $\mathrm{R} \$ 3.000,00$ e $8.000,00 /$ ano e a grande maioria, $77,1 \%$, renda anual inferior a $\mathrm{R} \$ 3.000,00$. Na região Sul, a participação da agricultura familiar é ainda mais significativa: corresponde a $90,5 \%$ dos estabelecimentos da região, ocupa $43,8 \%$ da área total, produz $57,1 \%$ do VBP e utiliza $43,3 \%$ dos montantes de crédito regionais. Os dados do censo também revelam a escassez de recursos da agricultura 
familiar nessa região: $91 \%$ dos estabelecimentos têm menos de 50 ha, 67,9\% menos de 20 ha e $51,4 \%$ têm renda anual inferior a $\mathrm{R} \$ 3.000,00$.

A baixa renda recebida pela grande maioria dos agricultores do país, especialmente por aqueles que detêm estabelecimentos com menos de 50 ha, explicam o êxodo rural e a redução do número de estabelecimentos agrícolas. Para Alves et al. (1999) a agricultura brasileira encontra-se numa fase de transição na direção de uma agricultura baseada na ciência, com um número pequeno de agricultores e que pouco emprega assalariados, próxima à dos países industrializados. Os autores consideram que, se o objetivo da política agrícola for manter o emprego e os estabelecimentos, ela não pode perder de vista as forças de mercado, que são antagônicas a tal objetivo. Assim, são fundamentais políticas de suporte ao desenvolvimento da agricultura familiar, considerando suas diferenças. É fundamental, também, que a pequena propriedade seja eficiente, frente à pequena base de recursos em que normalmente opera. Daí a importância de conhecer os sistemas de produção em uso, para embasar propostas de sistemas alternativos aos praticados pelos pequenos agricultores e que propiciem maior geração de renda. A introdução do risco na análise é uma questão relevante, uma vez que para as unidades de produção agrícolas familiares é plausível não considerar a hipótese de maximização dos lucros, uma vez que as decisões de produção e de consumo são tomadas pelo mesmo indivíduo ou unidade. Além disso, nos dias atuais, ao se deparar com as regras do mercado na definição dos preços dos produtos e das taxas de juros dos financiamentos, o agricultor deve aliar aos riscos de produção aqueles inerentes às variações nos preços.

Dada a grande extensão do território nacional e a diversidade de sistemas de produção adotados nas várias regiões do país, considera-se que estudos de caráter regional sejam importantes, no sentido de gerar resultados menos genéricos. O presente trabalho desenvolve-se no município de Boa Ventura de São Roque, na Região CentroSul do Paraná. 


\subsection{Objetivos}

O objetivo geral deste trabalho é desenvolver modelos que contibuam para uma maior compreensão do processo de tomada de decisão de diferentes tipos de agricultores familiares do município de Boa Ventura de São Roque - Paraná, estimando-se, também, a eficiência econômica dessas unidades de produção em condições de risco.

Objetivos específicos:

- Elaborar uma tipologia dos estabelecimentos agrícolas do município, identificando unidades de produção de maior interesse para o estudo;

- Selecionar através da Programação Linear, o mix de atividades agrícolas, pecuárias e de emprego externo de mão-de-obra para unidades de produção de diferentes tipos, que maximize a sua margem bruta, dadas as principais restrições a que estão submetidas e considerando o padrão tecnológico atual dos produtores;

- Traçar a fronteira de eficiência que forneça diferentes combinações de margem bruta e risco, para orientar o processo de tomada de decisão;

- Avaliar a taxa de aversão ao risco dos produtores analisados;

- Simular alguns cenários para as unidades de produção escolhidas, buscando dimensionar seu impacto sobre a renda dessas unidades.

\subsection{Organização do trabalho}

Além desta introdução, esta dissertação contém mais sete seções. Na seção 2 trata-se da caracterização do problema; descreve-se resumidamente a situação da agricultura familiar no Brasil, na região Sul e na área de estudos e discute-se sobre a restrição de recursos em que opera a agricultura familiar, sobre a necessidade de melhoria de sua eficiência e sobre o processo de tomada de decisão em condições de risco. A terceira seção discorre sobre o uso da programação matemática na agricultura, 
enfatizando a análise de fronteira, a programação linear e o modelo MOTAD, empregado no estudo para incorporação do risco. Em seguida, na quarta seção, especificam-se os procedimentos para a escolha das propriedades para modelagem, baseada na construção de uma tipologia de produtores. Na quinta seção descreve-se-se a metodologia para formulação dos modelos, para a construção da fronteira eficiente sob condições de risco e para a determinação do coeficiente de aversão ao risco dos produtores. Na sexta seção apresentam-se os resultados da modelagem dos sistemas de produção atuais. Na sétima, registram-se as conclusões. 


\section{IDENTIFICAÇÃO DO PROBLEMA}

A região Centro-Sul do Paraná está entre as mais pobres do estado e do país, fazendo parte do conhecido "Corredor da Fome". O estudo e a caracterização dessa região são importantes para a elaboração de políticas que visem superar os principais entraves ao desenvolvimento.

Gonçalves \& Souza (2001) descreveram detalhadamente a importância de se considerar a heterogeneidade do meio quando se trata da caracterização e proposição de alternativas para uma dada região. Nesse trabalho, onde foram propostas alternativas para o agronegócio no Vale do Ribeira - São Paulo, os autores advertem que ao caracterizar as condições do Vale deve-se ter claro que não há uma uniformidade nos indicadores econômicos e sociais e que propostas genéricas de intervenção, numa base marcada pela complexidade e heterogeneidade de situações, podem levar ao aprofundamento das disparidades regionais. Para proceder à caracterização, classificaram os municípios por faixas do Índice de Desenvolvimento Humano (IDH), para então se aprofundarem no que chamaram de "microrrealidades", dentro do pressuposto de que a diversidade de situações configura a necessidade de diferentes mecanismos de intervenção. Os autores mostraram a existência tanto da desigualdade inter-regional como da intra-regional, discutindo indicadores desagregados da região, identificando os municípios e os índices parciais formadores do IDH. Mostraram, ainda, que existe uma relação direta entre os níveis de pobreza mensurados pelo IDH e a renda. Admitem que na questão da renda, não apenas a diferença da verificada no Vale do Ribeira é enorme em relação às outras regiões, como no contexto intra-regional a disparidade é também muito expressiva. 
No presente trabalho também se parte do pressuposto que a caracterização da agricultura na área de abrangência, considerando suas diferenças, é a base para se alcançar os objetivos propostos. Assim, trata-se de fazer, num primeiro momento, um relato do perfil da agricultura familiar no Brasil e na região Sul, segundo o censo agropecuário de 1995/96 e um relato do perfil da área do estudo, utilizando tanto dados censitários como os resultados de trabalho realizado no âmbito do Convênio FAO/INCRA nos municípios de Pitanga e Boa Ventura de São Roque - PR.

\subsection{A agricultura familiar no Brasil segundo o censo agropecuário de 1995/96}

Através do Convênio FAO/INCRA, realizou-se uma análise da agricultura familiar no Brasil, segundo o censo agropecuário 1995/96 (Guanziroli et al., 2000). As informações apresentadas neste item estão baseadas nesse trabalho.

$\mathrm{O}$ universo familiar foi caracterizado pelos estabelecimentos que atendiam simultaneamente às seguintes condições:

a) a direção dos trabalhos do estabelecimento era exercida pelo produtor;

b) o trabalho familiar era superior ao trabalho contratado.

Adicionalmente, foi estabelecido um limite superior para a área dos estabelecimentos familiares, buscando evitar eventuais distorções que decorreriam da inclusão de grandes latifúndios no universo de unidades familiares, ainda que do ponto de vista conceitual, segundo o estudo, a agricultura familiar não seja definida a partir do tamanho do estabelecimento.

Em 1995/96, os estabelecimentos classificados como de agricultura familiar no Brasil representavam $85,2 \%$ do total dos estabelecimentos agrícolas, ocupavam $30,5 \%$ da área total e eram responsáveis por $37,9 \%$ do Valor Bruto da Produção (VBP) da agropecuária nacional, recebendo $25,3 \%$ do financiamento destinado à agricultura. $\mathrm{Na}$ 
região Sul, a agricultura familiar representava $90,5 \%$ dos estabelecimentos, ocupava $43,8 \%$ da área total, produzia $57,1 \%$ do VBP regional e era responsável por $43,3 \%$ dos financiamentos realizados na região.

Os dados do censo mostraram que no Brasil, 39,8\% dos estabelecimentos familiares possuíam menos de 5 ha, sendo que outros $30 \%$ possuíam entre 5 a 20 ha e $17 \%$, entre 20 e 50 ha. Esses números indicam que $87 \%$ dos estabelecimentos familiares no Brasil possuíam menos de 50 ha. Os agricultores familiares com área maior que 100 ha representavam apenas $5,9 \%$ do total mas ocupavam $44,7 \%$ de toda a área da agricultura familiar brasileira. $\mathrm{Na}$ região $\mathrm{Sul}, 20 \%$ dos estabelecimentos familiares possuíam menos de 5 ha; $47,9 \%$, entre 5 e menos de 20 ha e $23,2 \%$, entre 20 e menos de 50 ha. Por outro lado, a agricultura familiar era a principal geradora de postos de trabalho no meio rural brasileiro. Mesmo dispondo de apenas $30 \%$ da área, era responsável por $76,9 \%$ do pessoal ocupado. Na região Sul a agricultura familiar ocupava $84 \%$ da mão-de-obra utilizada na agricultura.

No que se refere ao nível tecnológico, existia no Brasil uma grande variação entre os agricultores familiares e patronais. Em 1995-96, entre os agricultores familiares, apenas 16,7\% utilizavam assistência técnica, contra 43,5\% entre os patronais. Entre os familiares este percentual variava de $2,7 \%$ na região Nordeste a $47,2 \%$ na região Sul.

Em 95/96, os investimentos realizados pelos agricultores familiares representavam $32 \%$ de todos os investimentos feitos na agricultura. As regiões que mais investiram foram o Sul $(44,2 \%)$ e Sudeste $(23,2 \%)$, representando juntas $67,4 \%$ de todos os investimentos realizados pelos agricultores familiares brasileiros nessa safra. $O$ principal destino dos investimentos realizados pelos agricultores familiares foi a formação de novas plantações (culturas permanentes e matas plantadas) e compra de animais, com $37,1 \%$ dos investimentos, seguidos por máquinas e benfeitorias $(25,2 \%) \mathrm{e}$ compra de terras $(16 \%)$. Observou-se que os agricultores familiares realizaram maiores investimentos por unidade de área que os patronais. 
Em termos do Valor Bruto da Produção de setores da pecuária brasileira tem-se que em 1995-96 os agricultores familiares eram responsáveis por 24\% do VBP total da pecuária de corte, por $52 \%$ da pecuária de leite, por $58 \%$ dos suínos e por $40 \%$ das aves e ovos. Em relação ao VBP de algumas culturas temporárias e permanentes, a agricultura familiar respondia por $33 \%$ no caso do algodão, $31 \%$ no do arroz, $72 \%$ no da cebola, $67 \%$ no do feijão, $97 \%$ no do fumo, $84 \%$ no da mandioca, $49 \%$ no do milho, $32 \%$ no da soja, $46 \%$ no do trigo, $58 \%$ no da banana, $27 \%$ no da laranja, $47 \%$ no da uva, $25 \%$ no do café e $10 \%$ no da cana-de-açúcar. Entre as cinco regiões, os agricultores familiares da região Sul eram os que mais se destacavam pela sua participação no VBP regional, sendo responsáveis por $35 \%$ da pecuária de corte, $80 \%$ da pecuária de leite, $69 \%$ dos suínos, $61 \%$ das aves, $83 \%$ da banana, $43 \%$ do café, $81 \%$ da uva, $59 \%$ do algodão, $92 \%$ da cebola, $80 \%$ do feijão, $98 \%$ do fumo, $89 \%$ da mandioca, $65 \%$ do milho, $51 \%$ da soja e $49 \%$ do trigo.

A rentabilidade por hectare era bastante superior na agricultura familiar quando comparada à patronal, em todas as regiões brasileiras. A agricultura familiar produzia em média $R \$ 104,00 /$ ha/ano contra $R \$ 44,00 /$ ha/ano dos agricultores patronais. $\mathrm{Na}$ região Sul, os agricultores familiares produziam anualmente $R \$ 241,00 /$ ha e os patronais, $R \$ 99,00 /$ ha.

A renda total ${ }^{2}$ e a renda monetária (excluído o valor referente ao autoconsumo) obtida nos estabelecimentos familiares demonstravam o potencial econômico e produtivo dos agricultores familiares, que, apesar de todas as limitações, não produziam apenas para subsistência, mas também geravam renda. A renda total dos estabelecimentos apresentava grande diversidade entre as diferentes categorias de agricultores. A grande maioria dos agricultores familiares $(68,9 \%)$ possuía renda total de

\footnotetext{
${ }^{2}$ A renda total foi assim calculada: $R T=V B P+R A I+V P I R-V T D$, onde $R T=$ receita total; $V B P=$ valor bruto da produção de todos os produtos, animais e vegetais, da exploração; $R A I=$ receita agropecuária indireta: venda de esterco+prestação de serviços+venda de veículos e implementos+outras receitas; $V P I R=$ valor da produção da indústria rural; $\mathrm{VTD}=$ valor total das despesas.
} 
zero até $R \$ 3.000,00$ ao ano; outros $15,7 \%$ possuíam renda total entre $R \$ 3.000,00$ e $R \$$ $8.000,00 ; 6,3 \%$ renda entre $\mathrm{R} \$ 8.000,00$ e $\mathrm{R} \$ 27.500,00$, e, apenas $0,8 \%$ dos agricultores familiares tinha renda total superior a $\mathrm{R} \$ 27.500,00$ por ano. Cerca de $8,2 \%$ dos estabelecimentos familiares apresentavam renda total negativa ou nula. Na Região Sul, $48,6 \%$ dos estabelecimentos familiares apresentava renda total superior a $\mathrm{R} \$ 3.000,00$ ao ano.

Tais dados servem para ressaltar a importância da agricultura familiar para o país, notadamente na região Sul, e o seu grande potencial de desenvolvimento, desde que conte com políticas de suporte que venham suprir as suas principais restrições.

\subsection{A área de estudo: município de Boa Ventura de São Roque ${ }^{3}$}

\subsubsection{Aspectos físicos}

O município de Boa Ventura de São Roque está localizado na região Centro-Sul do Paraná, no Terceiro Planalto ou Planalto de Guarapuava. Os solos predominantes, Latossolos Roxos distróficos, apesar da baixa fertilidade natural, respondem bem a correções de acidez e adubações. As condições de relevo, de suave ondulado a ondulado, exigem cuidados especiais com a erosão e a constante preocupação com práticas conservacionistas. De fato, a erosão é hoje um dos problemas sérios da área de estudos. Os municípios encontram-se a altitudes médias de 860 metros, apresentando clima do tipo $\mathrm{Cfb}$ na classificação de Koeppen, com geadas severas e frequentes. A média de precipitação anual está entre 1.250 e $2.000 \mathrm{~mm}$.

\footnotetext{
${ }^{3}$ Boa Ventura de São Roque emancipou-se do município de Pitanga em 1997. Em razão disto, em boa parte das informações apresentadas Boaventura de São Roque é ainda considerado como distrito de Pitanga.
} 


\subsubsection{Aspectos socioeconômicos}

A área de estudo vem se caracterizando por um processo de êxodo rural mais intenso que as médias observadas no estado do Paraná e da Região Sul do país. Segundo Bittencourt e Bianchini (1997), no período 1980/91, a população rural na Região Sul passou de 7,153 milhões para 5,726 milhões de habitantes (decréscimo de 19,5\%). No Paraná, no mesmo período, a população rural passou de 3,156 milhões para 2,250 milhões (decréscimo de $28,7 \%$ ). No município de Pitanga, a população rural reduziu-se em $37 \%$ no período, passando de 75 mil para 47,4 mil habitantes. Em 1991, a população rural era de 25,9\% na região Sul, 26,9\% no Paraná e 75,3\% em Pitanga. Segundo os autores, o êxodo é mais intenso nos estados, regiões e municípios em que os sistemas de produção agrícola são menos dinâmicos. Citando o estado de Santa Catarina, os autores afirmam que, por apresentar um maior equilíbrio entre produção de grãos e pecuária e uma maior integração entre agricultores e agroindústria, a sua população rural apresentou um decréscimo de apenas $9 \%$ no período analisado.

Analisando os dados do Censo Agropecuário de $1985^{4}$, identificou-se que os estabelecimentos com mais de 50 ha representavam cerca de $10 \%$ do total existente em Pitanga, ocupando $64 \%$ da área produtiva, e aqueles com mais de 100 ha representavam $4,4 \%$ do total, ocupando cerca de $49,7 \%$ da área. Os estabelecimentos de 10 a 50 hectares, nos quais se concentrava a maior parte da agricultura familiar, representavam $31,5 \%$, detendo $25,8 \%$ da área produtiva. No outro extremo tinham-se os estabelecimentos com menos de cinco hectares, que em 1985 representavam $37 \%$ do total, ocupando $4 \%$ da área produtiva, sendo que nestes estabelecimentos encontravamse os maiores níveis de pobreza. Em Pitanga, a maior parte da terra produtiva ( $86 \%$ da área) era cultivada pelos próprios proprietários que representavam $56,6 \%$ do total. Os arrendatários representavam $14,3 \%$ do total, os parceiros $11,8 \%$, e os ocupantes $17,3 \%$.

\footnotetext{
${ }^{4}$ Os dados referentes ao Censo Agropecuário de 1985 são extraídos de Bittencourt e Bianchini (1997).
} 
Dados do Censo Agropecuário de 1995/96 para o município de Pitanga mostraram que $74,4 \%$ dos estabelecimentos eram explorados pelos próprios proprietários e ocupavam $91,2 \%$ da área produtiva do município. A segunda categoria em importância era a de ocupantes, que representava $14,1 \%$ dos estabelecimentos e $4,1 \%$ da área. Os estabelecimentos dos arrendatários e parceiros representavam, respectivamente, 5,9 e 5,5\% do total. Com relação ao tamanho dos estabelecimentos, observou-se que $42,1 \%$ eram menores do que 10 ha e $50,6 \%$ tinham entre 10 a 100 ha.

Essas transformações verificadas na região, no que diz respeito à forma de ocupação da terra, devem estar relacionadas à presença de vários assentamentos da Reforma Agrária. Na mesoregião Centro Sul do Paraná estavam localizados cinco dos sete projetos de colonização realizados pelo Estado e 54 dos 112 projetos de assentamento do Paraná (Bittencourt \& Bianchini, 1997).

No município de Pitanga, em 1985, a lavoura do milho era a principal entre as temporárias, seguida da soja, do feijão, do trigo e do arroz. Entre as lavouras permanentes, a principal era a erva mate, que ainda é uma exploração extrativa no município. Com relação à produção animal, destacava-se a pecuária de corte e a suinocultura. Em pequena escala observava-se a presença do pecuária leiteira, avicultura, apicultura, sericicultura, tabagicultura, fruticultura, entre outros.

Dados do censo agropecuário 1995/96, trabalhados pelo Convênio FAO/INCRA para o universo da agricultura familiar, mostram que no município de Pitanga o milho estava presente em $77 \%$ dos estabelecimentos, sendo responsável por $26 \%$ do Valor Bruto da Produção Total (VBPT), enquanto a soja, presente em 6\% dos estabelecimentos, representava 10\% do VBPT. Em Boa Ventura de São Roque, a soja estava presente em $16 \%$ dos estabelecimentos, mas participava mais significativamente do VBPT (13\%) que o milho. Este, presente em $69 \%$ dos estabelecimentos respondia por apenas $10 \%$ do VBPT. Chama a atenção, ainda, o caso do feijão, que embora presente na maioria dos estabelecimentos, não chegava a responder por $2 \%$ do VBPT de Boa 
Ventura. A Tabela 1 mostra a situação dos dez mais importantes produtos da agricultura familiar desses dois municípios.

Tabela 1. Porcentagem dos estabelecimentos e participação no VBPT dos principais produtos dos municípios de Boa Ventura de São Roque e Pitanga - PR, no universo da agricultura familiar, safra 95/96.

\begin{tabular}{l|c|c|c|c}
\hline \multirow{2}{*}{ Produtos } & \multicolumn{2}{c|}{ Boa Ventura de São Roque } & \multicolumn{2}{c}{ Pitanga } \\
\cline { 2 - 5 } & \% Estabelecim. & VP/VBPT (\%) & \% Estabelecim. & VP/VBPT (\%) \\
\hline Soja & 16 & 13 & 6 & 10 \\
Milho & 69 & 10 & 77 & 26 \\
Feijão & 56 & 1,7 & 66 & 5,5 \\
Arroz & 30 & 0,3 & 43 & 0,8 \\
Hortaliças & 40 & 0,3 & 49 & 0,8 \\
Ext. vegetal & 70 & 1 & 68 & 1,2 \\
Suínos & 45 & 3,7 & 48 & 6 \\
Pec. Leite & 38 & 2,5 & 41 & 6 \\
Pec. Corte & 25 & 1,7 & 27 & 3 \\
Aves & 64 & 0,9 & 68 & 1,6 \\
\hline
\end{tabular}

Fonte: Censo agropecuário 1995/96

Elaboração: Convênio FAO/INCRA

VP: Valor da produção de cada produto; VBPT: Valor bruto da produção agropecuária do município

Em estudo de campo realizado em 1996/1997, junto a uma amostra de 34 propriedades 5 , Bittencourt e Bianchini (1997) definiram, tendo por base a renda

\footnotetext{
${ }^{5}$ A base de dados referente ao mencionado estudo foi utilizada nesta dissertação para a construção de uma tipologia que apoiou a escolha das propriedades para modelagem dos sistemas de produção, conforme se verá adiante.
} 
agropecuária $(R A)^{6}$ dos estabelecimentos, as seguintes categorias sociais de produtores de Boa Ventura de São Roque:

1. Agricultor familiar

- Agricultor familiar em descapitalização/descapitalizado: $R A$ inferior a $\mathrm{R} \$$ $3.000,00 /$ ano

- Agricultor familiar de transição: $R A$ entre $\mathrm{R} \$ 3.000,00$ e $\mathrm{R} \$ 9.000,00$ /ano

- Agricultor familiar capitalizado: $R A$ superior a $\mathrm{R} \$ 9.000,00 / \mathrm{ano}$

2. Agricultor patronal

$\mathrm{Na}$ amostra, entre os agricultores familiares (32 casos), 15,6\% estavam entre os capitalizados, $37,5 \%$ entre os de transição e $46,9 \%$ entre os descapitalizados. Os autores esclarecem que a maior parte dos assentados da reforma agrária foram classificados como familiares descapitalizados, devendo-se considerar, entretanto, que por se tratar de assentamentos recentes, muitos deles apresentavam sistemas de produção pouco rentáveis no momento do estudo, tendo, no entanto, potencial para desenvolvimento mediante a existência de suporte governamental (crédito subsidiado, assistência técnica, etc). Um maior detalhamento das rendas agropecuárias médias recebidas pelos agricultores familiares são apresentadas na Tabela 2.

\footnotetext{
${ }^{6}$ A renda agropecuária foi calculada da seguinte forma: $R A=P B-C I-D-A-I-J-S$, onde $R A=$ renda agropecuária; $P B=$ produção bruta da exploração; $C I$ = consumo intermediário, que se refere aos valores dos bens (insumos) e serviços comprados e consumidos na produção/ano; $D=$ depreciação; $A=$ valor dos arrendamentos e aluguéis pagos aos proprietários das terras; $I=$ impostos e taxas ligados à propriedade rural; $J=$ juros e encargos financeiros referentes a empréstimos bancários; $S=$ salários pagos à mão-de-obra contratada.
} 
Tabela 2. Renda agropecuária média por categoria de agricultores familiares ( $\mathrm{R}$ /ano).

\begin{tabular}{l|c|c|c}
\hline \multirow{2}{*}{ INDICADOR } & \multicolumn{3}{|c}{ AGRICULTOR FAMILIAR } \\
\cline { 2 - 4 } & Capitalizado & Em transição & Descapitalizado \\
\hline Renda agropecuária & 17.600 & 5.017 & 1.860 \\
Valor autoconsumo & 3.155 & 1.972 & 1.561 \\
Renda agropecuária/UTF & 4.374 & 1.899 & 704 \\
Renda agrop./Area total & 287 & 234 & 156 \\
\hline
\end{tabular}

Fonte: Bittencourt e Bianchini (1997)

A renda agropecuária por unidade de trabalho familiar foi, ao valor do salário mínimo (SM) na época do estudo, de 3,2 SM mensais para o agricultor familiar capitalizado, 1,4 para o de transição e 0,5 para o descapitalizado. Observa-se, ainda, que o valor do autoconsumo representava $84 \%$ de toda a renda agropecuária do agricultor descapitalizado. Os principais sistemas de produção adotados, de acordo com a participação das atividades produtivas na formação da renda agropecuária, no capital empregado na produção e na área destinada a cada atividade eram:

a) Sistema soja/aveia/trigo+suínos

Este sistema estava geralmente associado a agricultores patronais e a familiares capitalizados, dado que a soja exigiria uma área mínima de cultivo e a suinocultura integrada dependeria de um capital considerável para o início e manutenção da atividade. A adoção deste sistema requeria, ainda, que as propriedades contassem com boas estradas, fator decisivo na seleção de parcerias efetuada pela agroindústria.

b) Sistema soja/aveia/trigo +milho

Os agricultores que desenvolviam este sistema dependiam da escala de produção para obterem uma renda satisfatória, tendo em vista a necessidade de investimentos em máquinas e equipamentos. Este sistema estava vinculado principalmente a agricultores familiares capitalizados e patronais, estando presente também entre os familiares de transição, que contratavam o serviço de máquinas. 
c) Sistema milho+criações

Este sistema apresentava-se como uma opção para os assentados da reforma agrária e para outros produtores familiares com nível de capitalização mais baixo, uma vez que os investimentos realizavam-se aos poucos, através do melhoramento dos rebanhos via cruzamentos e melhoria gradual das pastagens. A pecuária leiteira, entretanto, acabava constituindo-se numa opção somente para os produtores que contavam com melhores condições de acesso e boa localização em relação ao laticínio, além de terem condições de atender as exigências crescentes dos laticínios quanto ao volume e qualidade da produção.

d) Sistema fumotautoconsumo

Este sistema era típico dos agricultores familiares de transição. O fumo ocupava uma área pequena, que variava normalmente de 0,8 a 2 ha por produtor, sendo uma atividade mão-de-obra intensiva. $O$ fumo, além de garantir uma renda monetária para a família, deixava excedentes de calcário e adubos para culturas subsequentes. Apesar de apresentar um dos maiores retornos/ha entre as atividades analisadas, o fumo era normalmente mantido como uma opção temporária, até o pagamento dos investimentos, dado o alto uso de agrotóxicos, a alta necessidade de mão-de-obra e a difícil relação com as agroindústrias.

e) Sistema milho + autoconsumo

Tal sistema era comum entre os agricultores descapitalizados, embora aparecesse também entre os agricultores familiares de transição, sendo o mais conhecido e utilizado pelos agricultores assentados em seus primeiros anos na região. Isto para garantir a manutenção da família enquanto se implementavam outras atividades produtivas com os recursos disponíveis em diferentes linhas de crédito. Este sistema produzia pouca renda monetária, destinando-se principalmente à sobrevivência da família enquanto outras atividades não garantiam retornos econômicos. 
f) Sistema de autoconsumo

Sistema predominante entre os agricultores familiares mais descapitalizados, entre os quais se encontravam: assalariados rurais fixos ou temporários com moradia em pequenos estabelecimentos rurais; os proprietários, arrendatários ou parceiros com pouca terra ou com baixo potencial produtivo e normalmente com alguma renda externa (pensões, aposentadorias); agricultores que viviam em completa pobreza, contando apenas com a pouca produção para o consumo familiar e a venda esporádica de mão-deobra.

Entre as conclusões de seu trabalho, os autores enfatizam a necessidade de se incrementar a renda dos produtores, principalmente dos segmentos de transição e descapitalizados. Isto pode se dar, segundo eles, tanto através do aumento da produtividade e redução dos custos de produção das atuais culturas, como da inclusão de outras atividades aos sistemas de produção.

Cruzando as categorias sociais com os sistemas de produção praticados, os autores chegaram a 10 grupos ou tipos de produtores. No interior destes grupos, entretanto, existiam estabelecimentos com dotações de recursos produtivos ainda bastante heterogêneas, principalmente terra e mão-de-obra, o que poderia significar distintos potenciais para a adoção de novas alternativas produtivas. Por esta razão, associada à dificuldade de operacionalizar a construção de coeficientes técnicos para o grande número de tipos encontrados, tal tipologia não foi empregada nesta dissertação, embora o trabalho tenha contribuído muito para o conhecimento da agricultura local.

\subsubsection{Instituições atuando junto à agricultura familiar na área de estudos}

Existem na região diversas instituições que vêm trabalhando na busca de alternativas aos sistemas de produção regionais. Entre elas, destacam-se:

- Fundação para o Desenvolvimento Econômico Rural da Região Centro Oeste do Paraná (Fundação RURECO), ONG que vem desenvolvendo trabalhos com 
bovinocultura de leite, apicultura, melhoramento de solos/ práticas conservacionistas e plantas medicinais, sendo este último um trabalho de pesquisa em parceria com a EMBRAPA;

- Instituto Agronômico do Paraná (IAPAR), que conta com uma estação experimental no município de Guarapuava, onde já se desenvolveram pesquisas com fruticultura e pastagens;

- Empresa de Assistência Técnica e Extensão Rural do Paraná (EMATER - PR), Secretaria Agropecuária Municipal de Pitanga e Departamento de Agricultura e Desenvolvimento do município de Boa Ventura de São Roque, que prestam assessoria técnica aos produtores familiares da região;

- Cooperativa de Crédito Solidário de Pitanga (CRESOL-Pitanga), que pode dar apoio financeiro e técnico à implementação de novas propostas tecnológicas, através de sua linha de crédito rural $^{7}$ e acompanhamento técnico. A ela estão vinculados produtores de pequeno porte;

- Cooperativa Agropecuária Mourãoense Ltda (COAMO), que participa na comercialização de produtos e insumos e presta assessoria técnica à produção e comercialização de seus associados, normalmente produtores de maior porte.

$\mathrm{Na}$ formulação da tipologia, escolha das propriedades e construção dos coeficientes técnicos para a modelagem dos sistemas de produção representativos, contou-se com a colaboração de agricultores, técnicos e pesquisadores dessas instituições.

\footnotetext{
${ }^{7}$ As Cooperativas de Crédito Solidário buscam organizar a poupança dos agricultores e, ao captá-las a um menor custo, teriam condições de remunerar melhor, fornecendo crédito para os próprios agricultores. Prestam serviços bancários com menores custos e taxas, dada sua menor estrutura de funcionamento. Sua atuação vem se dando em nível dos municípios e no máximo regional. Com diretoria e sócios locais, o acompanhamento da aplicação dos recursos é facilitado. Atualmente o sistema CRESOL é composto por vinte e três cooperativas, numa área de abrangência geográfica de 82 municípios nos estados de Santa Catarina, Paraná e Rio Grande do Sul. Mantém um convênio com o Banco do Brasil onde ela guarda o dinheiro, faz a compensação de cheques e de outros papéis. Os recursos do PRONAF para custeio são repassados via Banco do Brasil. Também tem convênio com o BRDE, e BNDES para repasses de recursos para investimento. No Paraná, a primeira cooperativa do sistema CRESOL foi criada em 1995.
} 


\subsection{A problemática da restrição de recursos, a melhoria da eficiência e o capital humano disponível}

A restrição de recursos que caracteriza a pequena agricultura, freqüentemente suscita discussões sobre a necessidade de melhoria de sua eficiência. Schultz (1965) defende a hipótese que o setor agrícola, em grande número de países pobres, é relativamente eficiente no uso dos fatores de produção à sua disposição. Não considera que as comunidades de agricultura tradicional de baixa renda possam aumentar substancialmente a produção agrícola somente através de uma distribuição mais eficiente desses fatores. Entretanto, em seu estudo Schultz analisa comunidades de agricultura tradicional muito pobres, onde o estado dos conhecimentos, das preferências e dos motivos para manter e adquirir as fontes de renda permanecem constantes. Não podemos enquadrar a agricultura da área de estudos nessa situação; pelo contrário, ela vem sofrendo mudanças muito significativas em seu aparato tecnológico, principalmente a partir da entrada da cultura da soja em meados dos anos 70 . Schultz considera, ainda, que a capacidade do pessoal ligado à agricultura constitui o principal fator para explicar as diferenças entre os países no sucesso do setor agrícola em contribuir para o desenvolvimento econômico, atribuindo às diferenças em terras pequena importância e às diferenças entre qualidade do capital material importância substancial.

Hayami e Ruttan (1975), citados por Araújo (1997), observaram que as origens das diferenças de produtividade agrícola classificam-se em três grandes categorias: a) quantidade e qualidade dos recursos disponíveis; b) tecnologia, incorporada no capital fixo; e, c) capital humano, incluindo educação, habilidades, grau de conhecimento e capacidade geral da população como um todo.

Diversos autores enfatizam em seus trabalhos a necessidade da busca de alternativas geradoras de renda para a pequena propriedade. Em geral são céticos na manutenção do papel preponderante que, de modo geral, os pequenos agricultores 
atribuem à produção de grãos (em especial, milho e feijão) como principal fonte de renda.

Um estudo da Universidade Estadual do Rio de Janeiro ${ }^{8}$ mostrou a existência de 6,7 milhões de agricultores no Brasil com baixos índices de produtividade a ponto de porem em risco a própria subsistência. Desses, 5,1 milhões eram pequenos produtores familiares, sendo que $60 \%$ deles se encontravam no Nordeste. Esse estudo, conduzido para mapear a clientela da Reforma Agrária, apontava ainda para o seguinte fato: "é na lavoura temporária que está o nó da questão agrária brasileira: 2,6 milhões de lavradores de baixa produtividade estão envolvidos nessa atividade - em especial na cultura do feijão e do milho". Apontava, ainda, para a necessidade de se buscar atividades geradoras de renda monetária, de se melhorar o acesso ao crédito, à tecnologia e ao mercado.

Gonçalves \& Souza (2001), tratando do Vale do Ribeira, compararam os IDHs municipais com as principais atividades que competiam pelo solo dos municípios, não encontrando relações entre IDH e atividade produtiva predominante. Em outras palavras, tomando o exemplo da bovinocultura de corte, ela podia ser encontrada como atividade relevante tanto em municípios de baixos como de altos IDHs. O mesmo fato se repetia para a grande maioria das atividades analisadas. Os autores chamaram a atenção, entretanto, para o fato de que a concentração da produção de cereais como lavoura relevante se desse nos quatro municípios mais pobres da região. Afirmaram que a presença de certa atividade em si pouco representa se a parcela preponderante do valor agregado no produto final se dá fora da região, tornando-a marginal ao não internalizar mecanismos multiplicadores de renda. Consideraram improdutivas alocações de recursos que buscassem a mera expansão das atividades tradicionais, ainda que no sentido do aumento da produtividade. Em seu trabalho propuseram um desenho de investimento para a região que modificasse a base produtiva no sentido de incorporar novos ramos de

\footnotetext{
${ }^{8}$ Publicado no Jornal "O Estado de São Paulo" de 14 de maio de 1999, p. A14.
} 
produção, aproveitando as vantagens comparativas, para que, induzidas pelo investimento, transformassem-se em vantagens competitivas. A proposta se baseou na implantação de uma moderna horticultura de mesa como base para o desenvolvimento regional.

Analisando o caso do estado de Santa Catarina, Holz (1993), citado por Araújo (1997), admitiu a hipótese de que a pequena unidade de produção agrícola remunera mal os fatores de produção na maioria dos empreendimentos. Em seu trabalho com 420 propriedades que constituíam "grupos de gestão", o autor encontrou que $43 \%$ dos grupos não atingiram ä remuneração de um salário mínimo por Unidade de Trabalho Homem (UTH) por mês, $68 \%$ não atingiram dois salários mínimos por mês e apenas $12 \%$ ultrapassaram três salários mínimos. Quanto à remuneração do capital, 50\% dos grupos não atingiram a taxa de remuneração de $6 \%$ ao ano. Observou ainda que $43 \%$ dos grupos tinham prejuízo real na propriedade agrícola. Para esses grupos, o autor concluiu que a sobrevivência na agricultura não era viável a não ser que ocorressem mudanças no cenário econômico ou na gestão dos empreendimentos. $\mathrm{O}$ autor previa, ainda, que $43 \%$ dos trabalhadores do setor sentir-se-iam tentados a buscar empregos em outros setores, com remuneração mínima de um salário mínimo. Igualmente, $50 \%$ das terras poderiam ir para o mercado de arrendamento ou até de troca, por absoluta falta de capitalização dos proprietários na atual forma de exploração.

Existe o consenso que a agricultura familiar deve contar, além dos instrumentos de política agrícola, com opções produtivas e de utilização de recursos que possam melhorar os seus ingressos monetários, considerando seus fatores limitantes. Entre esses fatores limitantes, encontra-se a pequena disponibilidade de terra para expandir a produção agropecuária. É de se esperar, portanto, que para aumentar a produção e a rentabilidade, será preciso obter ganhos de produtividade via adoção de novas tecnologias e/ou melhoria da eficiência dos estabelecimentos. 
Segundo Conceição (1998), eficiência econômica é entendida como o processo de produção em que os custos são minimizados, dados os preços dos fatores (eficiência alocativa) e, ao mesmo tempo, a produção ocorre na fronteira tecnológica (eficiência técnica). A eficiência econômica representa, portanto, uma combinação das eficiências técnica e alocativa. Ressalta que um dado processo produtivo pode ser eficiente do ponto de vista alocativo, mas não do ponto de vista técnico, ou vice-versa. Nesses dois casos, não se obtém a eficiência econômica.

A noção de fronteira eficiente empregada no presente estudo estaria ligada aos conceitos de eficiência técnica e alocativa. A fronteira eficiente é construída a partir de uma relação entre as margens brutas (maximizadas) e os desvios dessas margens (proxy de risco). Ora, ao se melhorar a eficiência técnica e alocativa das propriedades eleva-se o patamar que está sendo empregado no cálculo dos máximos retornos, deslocando a curva (fronteira) para cima, no espaço risco/renda.

Gomes (1996), citado por Tupich (1996), esclarece que a firma só será eficiente tecnicamente, alocativamente e eficiente na escala se a produção e a utilização de insumos coincidirem com a função maximizadora de lucros. Esta conjunção, entretanto, parece difícil de ocorrer no caso da pequena produção de natureza familiar. Isso porque, na empresa familiar as decisões de produção e de consumo são tomadas pelo mesmo indivíduo ou unidade, sendo que a maximização do lucro não é necessariamente consistente com a maximização da utilidade (Peres, 1976). Este assunto será retomado ao tratar da tomada de decisão sob risco.

Para Pereira Filho (2000), a eficiência pode estar relacionada a fatores de ordem econômica, ambiental, social, etc. Analisando uma amostra de 44 pequenos produtores na região Recôncavo da Bahia, o autor conclui que a pequena propriedade familiar da região estudada é tecnicamente eficiente, aproximando-se do nível de produção ótimo dada a tecnologia empregada, o que significa que ganhos de produtividade marginal dos fatores de produção somente seriam possíveis graças à mudança tecnológica. Por outro 
lado, os produtores não estariam conseguindo atingir a eficiência alocativa, ou seja, não estariam conseguindo ajustar a combinação de insumos que levaria ao custo mínimo.

Ineficiências também foram observadas em outros tipos de exploração agrícola. Analisando uma amostra de produtores representantes da agricultura comercial brasileira, Conceição (1998) chegou à conclusão que os produtores não conseguem explorar a tecnologia disponível em sua plenitude, sendo a eficiência técnica média da amostra de $73,08 \%$, variando entre as fazendas no intervalo de $41,47 \%$ a $93,09 \%$. Cerca de $34 \%$ das unidades produtoras apresentaram níveis de eficiência técnica abaixo da média estimada. A autora ressalta a importância de tal constatação no cenário atual, onde a competitividade passa a ser um dos requisitos a ser alcançado. Assim, além de se gerar e divulgar novas tecnologias, é necessário um esforço adicional para que o uso da tecnologia disponível se dê de forma eficiente. Reforça-se, a partir de tais resultados, a importância de se identificarem variáveis que possam explicar variações nos níveis de eficiência, ou dito de outra forma, é muito importante investigar o papel que aí desempenham variáveis de capital humano. Especificamente, a autora parte da hipótese de que educação formal, extensão pública e particular, experiência do produtor e acesso à informação têm efeitos positivos sobre os níveis de eficiência técnica, chegando à conclusão que, na amostra analisada, as variáveis mais importantes foram a experiência, extensão privada e fontes alternativas de informação (rádio).

Peres (1976), admite em seu trabalho, que o fato das propriedades não se situarem na fronteira eficiente de retorno/risco (fato que poderia ser considerado como ineficiência) pode ser devido à dificuldade de reprodução, através do modelo, de todas as características comportamentais dos produtores, ou mesmo, que informações relevantes não sejam consideradas na análise.

Considerando que as ineficiências podem ser decorrência de uma combinação inadequada (sub-ótima) dos fatores de produção disponíveis ou até da utilização de insumos acima do tecnicamente recomendável, a gestão das unidades produtoras 
constitui um fator decisivo para a rentabilidade do empreendimento e sua sobrevivência num mercado cada vez mais competitivo. Por outro lado, a redução das ineficiências pode representar ganhos na produtividade das unidades de produção e na economia como um todo.

Portugal (1998) afirma que o negócio agrícola brasileiro tem sido fortemente afetado pelas transformações econômicas, políticas e sociais que vem mudando a face do país. A abertura do mercado pressiona os produtos agrícolas e as respectivas cadeias produtivas por maior competitividade, onde tecnologia e gestão passam a representar fatores diferenciadores. Por outro lado, aumenta a preocupação da sociedade com a questão da sustentabilidade ambiental. Nesse contexto, Quirino (1998) aponta que entre as áreas consideradas de alta prioridade para o sistema nacional de pesquisa agropecuária, estão a modelagem de agrossistemas e a análise socioeconômica dos impactos positivos e negativos resultantes da adoção de novas tecnologias de produção agropecuárias. Relatando um estudo acerca das perspectivas da agricultura brasileira no que diz respeito ao seu impacto no meio ambiente, afirma que um ponto básico ao desenvolvimento sustentável é a atuação da Embrapa junto às regiões menos desenvolvidas e com mais dificuldade de acesso às técnicas, para levar conhecimentos que permitam a adaptação dos métodos tradicionais, incentivando o abandono das técnicas consideradas predatórias e causadoras de degradação ambiental. Considera fundamental o apoio à pequena propriedade, visando à adequação das tecnologias à cultura de cada região como caminho para a preservação ambiental.

Assim, estudos que tratem da modelagem de sistemas de produção alternativos que considerem as restrições dos diferentes tipos de sistemas de produção, são importantes para a melhoria da eficiência econômica e da sustentabilidade das pequenas propriedades. 


\subsection{Tomada de decisão sob risco}

$\mathrm{Na}$ agricultura, a hipótese de maximização do lucro nem sempre é a mais apropriada, pois os planos de produção são determinados pelos objetivos do produtor, que por sua vez são influenciados pela sua apreciação sobre os riscos envolvidos nas diferentes atividades. Dessa forma, a introdução do risco na análise é uma questão relevante. Isto porque nem sempre os produtores escolhem atividades unicamente pelo retorno monetário que elas possam gerar, mas consideram incertezas, tais como quebra na produção das culturas, mudanças nas condições de comercialização e preços, etc. Conforme mencionado anteriormente, para empresas agrícolas familiares é plausível não considerar a hipótese de que elas maximizem lucro, pois aí as decisões de produção e de consumo são tomadas pelo mesmo indivíduo ou unidade, sendo a maximização do lucro não necessariamente consistente com a maximização da utilidade. Para Berdegué (1987) o pequeno agricultor não busca lucro máximo em todas e em cada uma das atividades agropecuárias de seu estabelecimento. Ele busca um produto total suficiente para assegurar a estabilidade e a sobrevivência de sua família e de sua unidade de produção cada atividade contribui de modo particular para se alcançar esse produto total.

Knight (1921), considera o risco como uma situação onde os eventuais resultados obedecem uma distribuição de probabilidade conhecida. Um problema de decisão envolve incerteza quando não são conhecidos os valores dessas probabilidades. Uma boa decisão, em condições de risco, depende das expectativas objetivas decorrentes da experiência passada do tomador de decisão (medidas objetivas) e das expectativas subjetivas que expressam a sua capacidade de antecipar o futuro.

Cruz (1984) caracteriza como situação de risco aquela onde o agricultor (ou pesquisador) tenha uma idéia subjetiva da probabilidade de ocorrência de um determinado evento. Admite que o conceito de incerteza coincide com o de risco com probabilidades subjetivas, podendo os termos risco e incerteza ser usados indistintamente. Ressalta que no ambiente agrícola, onde o conhecimento dos eventos é 
imperfeito, não existe o conceito de ótimo absoluto. Com isso, a hipótese clássica de maximização de lucro pode não ser sempre a mais apropriada no contexto agrícola, podendo o agricultor, por exemplo, ter como objetivo a segurança de uma renda mínima. Desta forma, a avaliação das alternativas tecnológicas devem levar em conta o seu desempenho também em condições desfavoráveis. O autor resume: "para o agricultor, o que melhor caracteriza o risco é o desvio entre aquilo que ele espera ganhar e o que ele teme ganhar (perder?) em situações desfavoráveis" (Cruz, 1984, p. 238).

Peres (1981) afirma que o processo de decisão dos agricultores brasileiros ocorre em condições de altos graus de risco, fato que impõe na agricultura custos ou ineficiências cujo conhecimento pode ajudar na compreensão das baixas produtividades. A principal estratégia que a pequena propriedade utiliza para administrar tanto os riscos de produção quanto de preços é a diversificação da produção. A autora, analisando as causas da baixa produtividade do milho na região de Ribeirão Preto, São Paulo, estimou em seu trabalho as correlações entre as margens brutas das diversas atividades das explorações agrícolas. Concluiu que a existência de valores negativos altos, em termos absolutos, propicia vantagens significantes à diversificação de atividades como forma de redução de risco.

A diversificação de atividades possibilita aos produtores uma melhor distribuição dos seus recursos de produção no tempo e no espaço e certa estabilidade na renda, dadas as variações nas condições climáticas e de mercado a que estão sujeitos. Assim, o fator risco deve ser considerado em estudos que busquem alternativas para a exploração agropecuária. 


\section{USO DA PROGRAMAÇÃO MATEMÁTICA NA AGRICULTURA}

Neste capítulo realiza-se uma revisão da literatura acerca da programação matemática na agricultura, enfocando de modo especial a análise de fronteira e a programação linear. Especifica-se, em seguida, o modelo MOTAD, que será utilizado neste trabalho para introdução do risco na análise.

\subsection{Análise da fronteira eficiente}

A eficiência econômica de uma empresa pode ser representada a partir da estimativa de uma função de fronteira. A função-fronteira é o "padrão" em relação ao qual será medida a eficiência da firma observada. Este é o caso da função de produção, função custo e função lucro, todas elas definidas como conceito de fronteira. Tomando o exemplo da função de produção-fronteira, ela representa o máximo produto possível, dado um volume de insumos. A importância desta abordagem na análise de eficiência é que desvios destas fronteiras podem ser interpretados como ineficiências (Forsund et al, 1980).

Markowitz (1952), desenvolveu, através da programação quadrática, uma técnica para obter a chamada fronteira eficiente, que consiste no conjunto das possíveis atividades que tenham a propriedade de mínima variância (V), associada ao nível de receita esperada (E) (fronteira de eficiência $E-V$ ). O plano de produção preferido seria aquele que maximizasse a utilidade do produtor, ou, em outras palavras, aquele onde 
ocorresse a tangência da sua curva de indiferença com a fronteira eficiente, como mostra a figura 1 .

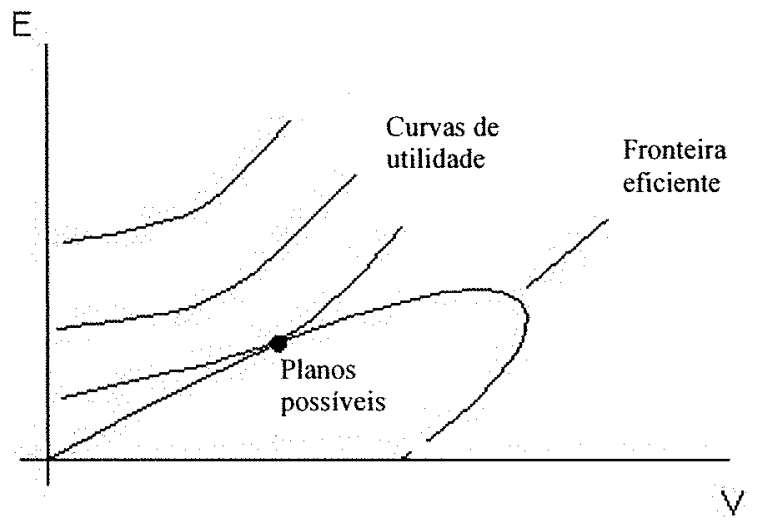

Figura 1 - A fronteira E-V como plano ótimo da empresa agrícola.

Fonte: Hazzel (1971)

Bauer (1990), afirma que a noção de fronteira é consistente com a teoria econômica básica do comportamento otimizador. Além disso, os desvios da fronteira podem ser interpretados como uma medida da eficiência com a qual as unidades econômicas perseguem seus objetivos técnicos ou comportamentais. As informações concernentes à fronteira e à eficiência relativa das unidades tomadoras de decisão têm aplicações na formulação de políticas.

Diversas abordagens podem ser empregadas para a construção das fronteiras de produção eficientes, e essas abordagens relacionam-se aos métodos empregados para estimar a função de produção.

Assumir uma forma funcional para a função de produção é considerado por alguns autores como uma restrição, pois a imposição de uma determinada forma funcional pode não corresponder à real estrutura da tecnologia de produção, resultando em erros de estimativa (Lambert \& Shonkwiler, 1995). 
Pode-se não especificar uma forma funcional particular para a função de produção. Nesse sentido, técnicas de programação linear são bastante utilizadas, sendo a eficiência medida a partir da distância de cada firma em relação a uma fronteira de produção construída como uma combinação de insumos-produtos.

No presente estudo vai se introduzir o risco na análise através do uso de uma aproximação linear ao enfoque da desenvolvido por Markowitz em 1952. Trata-se do modelo MOTAD, sugerido por Hazell em 1971. O MOTAD utiliza o desvio absoluto em relação à média das receitas como medida de risco, permitindo que o problema seja resolvido por programação linear. Assim, no modelo MOTAD, a construção da fronteira de eficiência é feita por meio de uma sequência de programação linear, gerando-se uma fronteira de eficiência econômica individual. Difere-se da programação pura pelo modo de construção da fronteira e pelo espaço bidimensional (retorno-risco) considerado (Araújo, 1997). A fronteira eficiente é definida como o lugar geométrico dos pontos correspondentes ao mínimo risco necessário para atingir determinado valor da função lucro, dadas as limitações de recursos das empresas. O produtor pode, de acordo com a teoria microeconômica, selecionar o plano mais eficiente de risco-renda para a empresa, entre todos os possíveis planos. Segundo Cruz (1984), o modelo MOTAD aponta um conjunto de soluções eficientes e cabe ao tomador de decisão a escolha da solução de acordo com as suas preferências, pois esta depende da função utilidade de cada um, que é subjetiva.

A opção pelo emprego do modelo MOTAD se deve ao fato de atender os objetivos do estudo com relativa simplicidade, além de já ter sido citado por diversos autores como instrumento adequado à gestão de empresas agrícolas e à formulação de políticas agrícolas (Peres, 1981; Azevedo Filho \& Peres, 1984; Figueiredo et al., 1993; Balverde, 1997; Araújo, 1997; Bittencourt et al., 1998). 


\subsection{Programação linear na agricultura}

Diversos estudos têm sido efetuados utilizando modelos matemáticos $\mathrm{e}$ estatísticos para auxiliar no planejamento das atividades agrícolas de empresas rurais visando a alocação eficiente dos recursos e uma maior rentabilidade.

Peres (1981) afirma que o método matemático da programação linear constitui uma técnica que permite trabalhar simultaneamente com um grande número de variáveis, acrescentando que a PL é um instrumento muito eficiente na análise econômica e na administração rural.

Contini (1984) reconhece na programação matemática um instrumento muito importante para a análise de experimentos e para a otimização de decisões na propriedade agrícola.

Dossa (1994) considera o uso da Programação Linear um enfoque alternativo na gestão da propriedade rural. O autor afirma que a PL é um instrumento que traduz adequadamente a realidade técnico-econômica da propriedade. Considera que para estudar o tema da mudança tecnológica é importante o uso de modelos que explicitem os fatores de produção mais restritivos dentro de um sistema de produção. Nesses modelos os fatores ou recursos utilizados são, geralmente, as disponibilidades de terra, mão-deobra, equipamentos. As restrições advêm do nível da disponibilidade de cada fator ou de outros aspectos, como o risco, por exemplo.

Quanto a limitações no uso da programação linear convencional na agricultura, Santos (1990) aponta a sua neutralidade com relação ao risco, a falta de bons coeficientes técnicos, não linearidade dos processos produtivos, etc. Dossa (1994) comenta que as dificuldades da utilização da PL, para se modelar uma exploração agrícola, estão mais fortemente ligadas a aspectos operacionais. Faz ver que, no início, há os problemas de formalização dos coeficientes técnicos e econômicos, que são muito 
difíceis de serem obtidos para se chegar, muitas vezes, a situações complicadas, a dados incompletos, insuficientes ou mesmo muito instáveis. Entretanto, tais restrições estarão presentes em qualquer estudo que empregue dados primários dos estabelecimentos, uma vez que a grande maioria dos estabelecimentos familiares do país não realiza uma contabilidade criteriosa.

Outra restrição mencionada é o fato de que a programação linear, quando usada na determinação do nível ótimo de atividades agropecuárias, tende a produzir soluções extremas (de canto) ou equivalentes a altos graus de especialização. Peres (1976) comenta que estudos usando programação linear sem incorporar o risco tendem a uma especialização em direção ao produto de maior rendimento, especialização maior que a encontrada na prática. $\mathrm{Na}$ realidade, os agricultores diversificam mais que o indicado pelos modelos de programação linear por considerarem os riscos inerentes às atividades agrícolas. Para fugir de tais situações devem ser definidas criteriosamente as restrições a que a unidade de produção está sujeita e introduzir-se o risco na análise.

Diversos autores têm utilizado a programação linear no estudo da composição ótima de atividades para pequenas e grandes propriedades agrícolas.

Usando a PL para estudar o desempenho de propriedades familiares do município de Pitanga, Paraná, Fasiaben ${ }^{9}$, encontrou que, dentro do padrão tecnológico do agricultor descapitalizado, não existiriam alternativas geradoras de renda que apresentassem maior vantagem comparativa em relação à venda da mão-de-obra familiar. Para o padrão tecnológico do produtor capitalizado, a terra e o capital seriam fatores restritivos.

\footnotetext{
${ }^{9}$ FASIABEN, M.C.R. Programação Linear como instrumento de apoio à gestão da propriedade familiar: estudos de caso do município de Pitanga - PR. Piracicaba, 1999. 29p.
} 
Figueiredo et al. (1993) estabeleceram planos de produção agrícola para propriedades do assentamento rural localizado em Araras, São Paulo, selecionando, com o uso da Programação Linear, a composição das atividades produtivas mais rentável. Diferentes combinações entre lucro e risco foram analisadas com o modelo de Minimização do Desvio Absoluto Total (MOTAD). Os autores concluíram, com relação à mão-de-obra, que para níveis baixos de risco, parte da terra deveria deixar de ser cultivada e uma maior parte da força de trabalho deveria se ocupar fora da propriedade. Por outro lado, ao maximizar o lucro, o proprietário estaria usando mais mão-de-obra na propriedade, cabendo assim estender a exploração agrícola a atividades não tradicionais entre os assentados, incluindo as manufatureiras.

Araújo (1997), usando a mesma metodologia, analisou a eficiência econômica sob condições de risco de empresas agrícolas do sul de Santa Catarina. Encontrou como principal resultado da análise de eficiência a existência de um potencial médio de crescimento da margem bruta de $49,9 \%$ e de $62,59 \%$, quando o produtor adotar, respectivamente, o plano de máxima utilidade e de máximo retorno, dada a disponibilidade de fatores de produção e os padrões técnicos e econômicos das alternativas de produção.

\subsection{Especificação do modelo MOTAD}

O modelo MOTAD introduz risco no modelo determinista convencional de Programação Linear e consiste em (Hazell, 1971):

Minimizar

$\frac{S}{2}=\sum_{t=1}^{n} Y_{t}$ 
Sujeito a:

$$
\begin{aligned}
& \sum_{j=1}^{n} x_{j} D_{j}+Y_{t} \geq 0 \\
& f^{\prime} x=R_{0}
\end{aligned}
$$

$A x \leq b$

$x \geq 0 \quad$ e $\quad Y_{t} \geq 0$

Onde $n$ é o número de observações de uma amostra de margens brutas, $S$ é a soma dos desvios absolutos com relação às médias das margens brutas, $D_{t j}$ é o desvio em relação à margem bruta média da atividade $j$ no ano $t ; Y_{t}$ é uma variável auxiliar que mede a soma dos desvios quando ela é negativa, pois quando $\sum_{j=1}^{n} x_{j} D_{t j} \geq 0$, o $Y$ correspondente assume valor zero, devido às restrições (2) e (5); $R_{0}$ é o coeficiente de parametrização, crescendo a partir de zero até a solução máxima encontrada na Programação Linear.

A receita média para a cultura $j \overline{\left(r_{j}\right)}$ é dada por:

$$
\bar{r}_{j}=\sum_{i=1}^{n} q_{t j} P_{i j} / n
$$

onde $q_{t j}$ é a produtividade da cultura $j$ no ano $t$ e $P_{t j}$ é o preço recebido pelo agricultor para a cultura $j$ no ano $t$. 
O desvio em relação à média $\left(D_{t j}\right)$ é calculado por:

$$
D_{t j}=q_{t j} P_{t j}-\overline{r_{j}}
$$

Com os resultados dos processos de minimização correspondentes ao parâmetro $R_{0}$, constrói-se a "fronteira eficiente", que expressa o risco envolvido para atingir determinado nível de margem bruta. Haverá dessa forma um conjunto de soluções eficientes, cabendo ao tomador de decisão a escolha daquela que seja compatível com suas preferências (maior ou menor aversão ao risco). Dito de outra forma: quando a relação entre risco e retorno é tal que a cada nível de risco incorrido corresponde o máximo retorno para aquele nível de risco, ou, a cada nível de retorno corresponde o menor nível de risco necessário para atingir aquele retorno, tem-se uma fronteira eficiente. A cada ponto localizado na fronteira eficiente, corresponde um plano de cultivo para a empresa (Peres, 1981).

Revendo a literatura, Peres (1981) resgata as seguintes críticas ao enfoque E-V:

- Quando só se consideram os dois primeiros momentos de uma distribuição (média e variância) muitas informações são perdidas. Não se considerar o terceiro momento (assimetria) equivale à pressuposição de que as probabilidades de ocorrência de eventos (receitas brutas, no estudo da autora) maiores que a média (desejável) são iguais às de ocorrência de eventos menores que a média (indesejável);

- A escolha da variância ou do desvio absoluto com relação à média como proxy para risco é arbitrária, sendo que qualquer medida de dispersão em torno de uma média de valor central poderia ser utilizada;

- Consideram-se somente riscos associados à receita. Riscos de variações nos preços de insumos ou da não disponibilidade dos mesmos nos momentos oportunos não são considerados;

- As fronteiras eficientes são calculadas sem a utilização de qualquer informação sobre o grau de aversão ao risco dos agricultores. A determinação de pontos de equilíbrio 
depende da pressuposição sobre a forma explícita das curvas de utilidade dos agricultores, o que é muito difícil (ou até impossível) de ser determinado.

Balverde (1997) assinala a título de crítica ao modelo MOTAD, o fato de se utilizar os preços médios na especificação do risco. Considera razoável supor que o tomador de decisão utiliza conhecimentos acerca da natureza cíclica dos preços dos produtos e de outras informações de mercado, não considerando, portanto, simplesmente valores médios na configuração do risco. $\mathrm{O}$ autor avalia economicamente um sistema intensivo de produção pecuária no Uruguai, comparando o modelo MOTAD ao targetMOTAD, sendo que este último permite incorporar prognósticos do tomador de decisão em relação a retornos e risco. No estudo de Balverde, tanto as características dos tomadores e decisão (proprietários eram engenheiros agrônomos) quanto a relativa especialização da unidade de produção (bovinos de corte e ovinos), facilitaram a elaboração de prognósticos. $O$ autor considera que o target-MOTAD foi mais consistente com as percepções de risco dos tomadores de decisão e também foi coerente em termos de maximização da esperança de margens, na medida em que manteve os níveis mais altos permitidos da atividade relativamente mais eficiente. Entretanto, no caso de pequenos produtores que dispõem de escassas informações e orientações sobre os mercados de todos os produtos que compõem o seu amplo portfolio de atividades produtivas, o target-MOTAD pode não trazer vantagens explícitas.

Para contornar parte das limitações apontadas, para cálculo dos desvios nesta dissertação foram estimados modelos de tendência linear para as variáveis preços, produtividades e rendas, sendo os resíduos das regressões utilizados para representar os desvios. Tal procedimento parte do princípio que, embora os produtores não tenham informações mais elaboradas sobre os mercados de sua ampla gama de produtos, eles percebem as tendências dos preços e produtividades (desde que lineares) e orientam seus planos de produção considerando tais tendências. 
Assim, ao invés de calcular os desvios em relação à média da receita bruta, eles foram estimados, basicamente, subtraindo, da série histórica da receita bruta das diferentes atividades, o valor estimado por regressão linear simples. Para uma determinada atividade $j$ tem-se:

$$
D_{t}=P_{t} q_{t}-(\hat{\alpha}+\hat{\beta} t)
$$

onde $D_{t}$ representa o desvio calculado em relação à tendência; $P_{t}$ é o preço recebido pelo produtor, $q_{t}$ é a produtividade da cultura, $t$ é a tendência, $\hat{\alpha}$ é o coeficiente angular estimado e $\hat{\beta}$ o coeficiente estimado da variável independente na regressão.

Um maior detalhamento do cálculo dos desvios das diferentes atividades analisadas nos sistemas atuais de produção será feito na descrição da metodologia empregada na formulação dos modelos em condições de risco. 


\section{PROCEDIMENTOS PARA A ESCOLHA DE SISTEMAS DE PRODUÇÃo PARA MODELAGEM}

Para a modelagem dos sistemas de produção agrícolas atuais e alternativos e para a análise de sua eficiência econômica, deve merecer cuidado a escolha dos estabelecimentos que servirão de base para a obtenção dos coeficientes técnicos. No presente trabalho essa escolha se deu através dos seguintes passos:

a) Reuniões grupais com agricultores e técnicos locais, para levantamento exploratório dos fatores considerados relevantes para a diferenciação dos estabelecimentos agrícolas na área de estudos e breve descrição dos tipos considerados predominantes;

b) Elaboração de uma tipologia utilizando-se como base de dados entrevistas efetuadas em 34 propriedades do município de Boa Ventura de São Roque, no ano de 1997, no âmbito do Convênio FAO/INCRA ${ }^{10}$;

c) Confrontação de tais resultados e eleição das propriedades.

Tais procedimentos serão detalhados a seguir.

\footnotetext{
${ }^{10}$ A autora agradece a Gilson Bittencourt e Valter Bianchini pela concessão da base de dados referentes a tais entrevistas.
} 


\subsection{Fundamentos sobre tipificação de produtores rurais}

Um passo importante para o conhecimento da realidade agrícola de uma região é o estudo da diversidade dos sistemas de produção existentes, que pode refletir diferentes necessidades e potencialidades dos produtores. Os temas da classificação e caracterização de unidades de produção agrícolas têm sido bastante estudados, podendose citar o trabalho de Escobar \& Berdegué (1990), que relata uma série de aplicações de técnicas de tipificação e classificação de propriedades agropecuárias, principalmente com o objetivo de definir políticas de pesquisa e transferência de tecnologias e para a gestão de projetos de pesquisa em sistemas de produção agrícola. Para Dufumier (1990), a história de programas e projetos de desenvolvimento na América Latina mostra que ações eficazes na agricultura somente se dão sob a base do prévio conhecimento científico das realidades agrárias nas quais se pensa trabalhar.

No que diz respeito a metodologias para classificação de estabelecimentos agrícolas, Escobar \& Berdegué, anteriormente citados, afirmam que as técnicas de análise estatística multivariada são ferramentas idôneas, já validadas pela Rede Internacional de Pesquisa em Sistemas de Produção (RIMISP). Apontam como principal razão para a pertinência deste tipo de ferramenta o conceito de que a unidade de produção agrícola é multivariada, no sentido que faz parte de sua essência a idéia de vários componentes ou subsistemas interatuando no tempo e no espaço, assim como em relação com suprassistemas de diversas naturezas. As etapas de análise estatística empregadas pela maioria dos projetos da RIMISP são as seguintes:

1) Seleção de atributos que efetivamente se comportem como variáveis;

2) Análise fatorial para reduzir a dimensionalidade do problema;

3) Análise de conglomerados, empregando como variáveis um número reduzido de fatores principais;

4) Determinação dos tipos de sistemas de produção;

5) Descrição dos tipos selecionados; 
6) Análise discriminante para a classificação a posteriori de novos estabelecimentos, não contidos na amostragem inicial.

Monardes et al. (1993) criticam a abordagem metodológica da RIMISP pelas seguintes razões:

- Os tipos resultantes dificilmente representam um agrupamento natural de fácil identificação, dificultando agrupar outros estabelecimentos que não tenham feito parte da amostra estudada;

- A seleção das variáveis não considera as relações de causa-efeito, complementaridade ou substituição no modelo. Assim, se duas variáveis são estatisticamente correlacionadas, ao serem incluídas na análise multivariada apenas uma delas será considerada (por exemplo, o modelo pode selecionar apenas renda, ao estar esta variável correlacionada com qualidade do solo, excluindo uma informação que pode ser fundamental na definição de políticas de desenvolvimento).

Estes autores propõem a seguinte estrutura metodológica para classificação de propriedades:

1) Uso dos conceitos do enfoque de sistemas de produção e da teoria econômica da produção como marco conceitual global;

2) Definição ex-ante à análise, de sistemas de produção em nível de estabelecimentos, a partir de informações sobre as principais estruturas de produção (atividades produtivas: culturas ou criações) existentes na área de estudos. Esta etapa se realiza com base em informações proporcionadas e discutidas com técnicos que tenham um conhecimento profundo da área de estudo;

3) Os sistemas de produção definidos com base na estrutura de culturas e criações existentes na área estudada são avaliados mediante o uso de análise multivariada, com a finalidade de se comprovar se os mesmos constituem ou não grupos distintos em relação a algumas variáveis que representem diferentes dimensões dos processos de produção, consumo, adoção de tecnologias e outras;

4) Revisão ou comprovação dos tipos definidos ex-ante. 
No que diz respeito à seleção de critérios para a tipificação, Dufumier (1990) comenta que embora haja acordo sobre a importância da tipificação de produtores na definição de projetos de desenvolvimento agrícola, existem contradições no que diz respeito à seleção de critérios para diferenciá-los em categorias. O autor considera que a dificuldade reside na grande diversidade de fatores susceptíveis de determinar o comportamento dos produtores. Comenta que o procedimento mais simples seria privilegiar os elementos relativos à disponibilidade de recursos como terra, força de trabalho, meios de produção, capital, etc, porque para estes parâmetros normalmente existe informação disponível. Considera, ainda, que existem limites ao assumir a presença de relações mais ou menos estreitas entre esses dados estruturais e as diversas produções agrícolas nas explorações, uma vez que as combinações de atividades praticadas pelos agricultores não estão condicionadas somente pelos recursos disponíveis. Assim, a multiplicidade de combinações que se observa na prática é um reflexo da disponibilidade de recursos, considerando limitações agroecológicas e socioeconômicas. Variáveis como o acesso ao crédito e aos mercados, a utilização de mão-de-obra assalariada, a facilidade de abastecimento, a possibilidade de trabalhar fora da propriedade e obter retorno externo, etc, podem interferir nas decisões dos produtores e de alguma forma, resolver ou amainar limitações estruturais.

Pretende-se aqui ressaltar ainda que é fundamental, no momento de se definir os critérios para a classificação, a clareza dos objetivos da análise e o uso que se pretende dar aos resultados. Na presente dissertação interessa conhecer a diferenciação entre os estabelecimentos agrícolas na área de estudos para orientar a seleção dos casos que servirão de base para a modelagem dos sistemas de produção atuais e para simular alguns cenários concernentes aos tipos de produtores selecionados. Interessam aqui os fatores de diferenciação que reflitam o potencial dos estabelecimentos para a adoção de possíveis planos alternativos. 


\subsection{Critérios de diferenciação de produtores}

Esta etapa do trabalho teve por objetivo realizar uma análise exploratória sobre os fatores de diferenciação dos estabelecimentos rurais na área de estudos, segundo as opiniões de agricultores e técnicos com uma boa visão sobre a agricultura local.

Foram organizados dois grupos de discussão, um constituído por dez produtores e outro por três técnicos (dois agrônomos e um técnico agrícola) que atuavam na área de estudos. A definição do perfil dos participantes dos grupos foi feita em função dos objetivos do trabalho: buscou-se contar, entre os agricultores, com representantes dos possíveis tipos de estabelecimentos e que cada participante tivesse uma certa "visão regional", ou seja, que sua vivência o qualificasse a emitir opiniões além da organização da produção em seu próprio estabelecimento. A escolha de cada indivíduo, o convite e a organização da vinda dos participantes, estiveram a cargo da CRESOL-Pitanga.

Levou-se como tema de discussão a diferenciação observada entre os estabelecimentos dos municípios de Pitanga e Boa Ventura de São Roque. Preparou-se um roteiro de questões para a condução do tema, considerando tanto critérios de diferenciação mencionados na literatura, como os apontados por Bittencourt \& Bianchini (1997). Assim, o roteiro incluía questões relacionadas a: disponibilidade de fatores de produção (terra, mão-de-obra e capital); localização dos diferentes tipos em função das características de solo, relevo e clima dos municípios; atividades produtivas predominantes; resultado econômico obtido; diferenciação tecnológica; nível de capacitação dos produtores e capacidade de gestão; uso de crédito; nível de associativismo e freqüência relativa dos diferentes tipos, entre outras.

A estrutura prevista para as reuniões consistia:

- Apresentação dos participantes;

- Apresentação do objetivo da reunião;

- "Rodada geral", sobre os fatores de diferenciação, na visão dos participantes; 
- Seqüência de perguntas, segundo o roteiro previamente definido;

- Elaboração da tipologia.

Entretanto, na "rodada geral", nos dois grupos, a maioria dos critérios definidos no roteiro surgiram espontaneamente nas falas dos participantes. A preocupação centrou-se então, na ponderação desses critérios e na definição e descrição dos tipos, segundo o juízo de cada grupo.

\subsubsection{Diferenciação segundo parecer dos agricultores}

Ao serem questionados sobre quais seriam os principais fatores de diferenciação dos estabelecimentos agrícolas na região, a resposta mais imediata foi: a cultura da soja. Os produtores dividem a história do desenvolvimento agrícola na zona em dois momentos: antes e após a introdução da cultura da soja pelos gaúchos nos anos 70 . Isto porque a soja trouxe consigo todo um aparato tecnológico (mecanização, uso de insumos industriais) que modificou substancialmente os sistemas praticados até então, baseados na criação extensiva de animais nos faxinais ${ }^{11}$; na produção de milho, feijão, arroz e trigo prioritariamente para a subsistência; na extração da erva mate e na utilização da tração animal. Nos sistemas atuais, ainda a soja se constituiria num elemento diferenciador, embora ela tenha se disseminado mesmo entre os menores estabelecimentos, dada a possibilidade de se contar com a contratação do serviço de máquinas. Os produtores dividem, portanto, as propriedades entre as que têm e as que não têm soja. A soja teria contribuído, ainda, para a redução da diversidade dos sistemas de produção. Os produtores que cultivam soja a estariam mantendo como única (ou de longe, a mais importante) cultura comercial, associada a gramíneas para rotação (milho e cereais de inverno), sendo os demais cultivos destinados especialmente ao autoconsumo.

\footnotetext{
${ }^{11}$ Trata-se de terreno de uso coletivo para criação extensiva de animais, em especial suínos, bovinos e cavalos, onde a pastagem natural encontra-se sob a mata.
} 
Segundo os produtores, na área de estudos a soja estaria prioritariamente ligada aos estabelecimentos com maior disponibilidade de área, embora, como já foi mencionado, observem uma tendência de ampliação no número de pequenas propriedades a cultivar essa leguminosa. E aqui surge o segundo fator de diferenciação mais fortemente enfatizado: a área da propriedade. Associada ao fator declividade do terreno determina a viabilidade de mecanização (seja própria ou através da contratação do serviço) e as atividades produtivas a implementar. Os agricultores fizeram ver que existe um importante mercado de arrendamento de terra na região, o que faz com que se possa contar com áreas maiores que os terrenos próprios.

A disponibilidade de maquinaria própria foi o terceiro fator diferenciador, considerado condicionante da produção. Os produtores se diferenciariam pelo uso que fazem da tração animal ou mecânica, e neste último caso, se são proprietários da maquinaria ou se a utilizam de terceiros. Os proprietários têm muito maior liberdade de optar pelas atividades que desejem produzir, pois não correm o risco de não dispor das máquinas nos momentos que mais as necessitem. Observam ainda, que existe uma tendência à ampliação do aluguel de máquinas pelo fato dos próprios produtores acreditarem que a tração animal se constitui num "atraso" tecnológico.

A disponibilidade de mão-de-obra familiar foi outro fator apontado como preponderante. As propriedades onde a mão de obra é abundante podem se dedicar a culturas mais exigentes, como o feijão, que na maioria dos estabelecimentos ainda recebe capinas manuais, ou a outras atividades consideradas potenciais, como a sericicultura e a agricultura orgânica.

A fala de um produtor resume a discussão sobre os principais fatores de diferenciação: "O que diz o que se deve plantar e quanto plantar são os recursos que 
cada um tem. Se tem mais ou menos terra. Se é terra plana ou peral ${ }^{12}$. Se tem máquina... Se tem gente pra fazer o serviço..."

Outros fatores de diferenciação foram levantados como uso do crédito, nível de renda recebida, localização das propriedades em função de características microclimáticas, etc. Entretanto, estes foram considerados de menor importância comparativamente aos anteriormente descritos, ou em alguns casos, seriam conseqüências daqueles.

Aspectos referentes à formação e gestão foram mencionados apenas quando questionados a respeito. Quanto à formação, os produtores atribuíram maior valor àquela adquirida na prática, que passa de pais a filhos, que à escolaridade.

Finalmente, levantou-se como fator de diferenciação entre grandes e pequenos produtores a questão da conservação dos recursos. $O$ grupo considerou que os grandes têm menor preocupação com a conservação do solo e da água: desmatam mais e poluem mais pela utilização intensiva de agrotóxicos. Os pequenos teriam um apego muito maior à terra, herança que vem de seus antepassados.

\subsubsection{Diferenciação segundo parecer dos técnicos}

Os primeiros fatores de diferenciação citados pelos técnicos locais foram a área da propriedade, a tecnologia empregada e o nível de informação de que dispõem os produtores. O fator "tecnologia" estaria ligado predominantemente à mecanização, em especial ao uso do plantio direto, adotado inicialmente pelos grandes produtores, mas utilizado atualmente por parte significativa de médios e pequenos. A localização das propriedades em função do relevo, características de solo e clima também foi

\footnotetext{
${ }^{12}$ Trata-se de expressão para indicar os terrenos de maior declividade.
} 
considerada relevante, por condicionar a mecanização e influenciar em decisões técnicas como, por exemplo, a época de plantio.

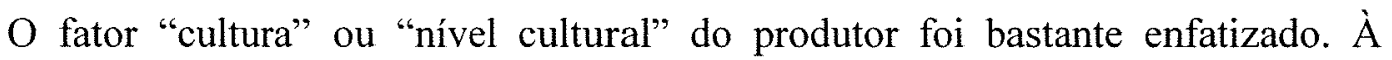
"cultura" estariam relacionados aspectos como nível de informação (ou interesse em obter a informação), motivação do produtor a mudanças e capacidade de gestão da propriedade. Os menores produtores estariam cada vez menos motivados com a agricultura. $^{13}$

A origem étnica do agricultor foi apontada como outro componente de diferenciação importante já que existiria relação entre etnia e "cultura". Assim, fatores como interesse, dedicação e persistência, que estariam ligados à "cultura" dos agricultores seriam consequência, em última instância, de sua origem étnica. Na opinião de um dos participantes, dado que existiriam diversas fontes de informação tecnológica na região (EMATER, COAMO, empresas privadas), o acesso à informação dependeria do interesse de cada um, havendo relação direta entre adoção de tecnologia e etnia do produtor. Esta opinião foi contestada, ao se diferenciar "disponibilidade de informação" com efetivo "acompanhamento técnico da propriedade", que se considerou como o verdadeiro condicionante à adoção de inovações. Concordou-se, então, que o acompanhamento das propriedades constituir-se-ia num diferencial importante, já que, dada a escassez de profissionais no serviço público e nas associações dos pequenos

${ }^{13}$ Schultz (1965) rebate afirmações de que questões "culturais" explicariam uma possível inclinação de determinados homens do campo ao ócio e uma provável falta de poupança nas comunidades agrícolas pobres, colocando que determinados comportamentos de trabalho e de poupança podem ser explicados por fatores econômicos, não sendo necessário apelar para diferenças culturais para explicá-los. Assim, seriam fracos os incentivos para que essas pessoas trabalhem mais porque a produtividade marginal do trabalho é muito baixa e os incentivos para economizarem mais que o fazem são fracos, porque a produtividade marginal do capital também é muito baixa.

Outra abordagem para esse assunto é dada por Dufumier (1990), que assume que frente à incerteza por fatores climáticos, econômicos e biológicos (pragas, doenças), os agricultores podem assumir o risco de formas diferentes: um determinado "acidente" poderia não ter conseqüências para alguns mas ser catastrófico para outros. 
produtores, estes teriam menor possibilidade de contar efetivamente com esse serviço, já que não poderiam pagar pelo mesmo.

Foram ainda levantados aspectos diferenciadores como o acesso ao crédito e a informações de mercado, renda extraída da produção agrícola e nível de organização dos produtores.

Na Tabela 3 apresenta-se um resumo dos principais fatores de diferenciação entre os produtores de Boa Ventura de São Roque, segundo os agricultores e técnicos locais.

A análise dos resultados obtidos a partir das opiniões dos agricultores, aponta para uma maior valorização de aspectos referentes à estrutura das propriedades como maiores responsáveis pelas diferenças observadas entre os produtores. Já entre os técnicos, embora tais fatores também tenham sido ressaltados, a maior parte da discussão girou em torno de fatores comportamentais.

A identificação e caracterização dos tipos segundo agricultores e técnicos tiveram muito em comum: em ambas a dotação de terra e capital (resumido principalmente em máquinas, que expressaria o nível tecnológico das propriedades) foi a base da construção dos tipos. O acesso ao crédito apareceu na descrição dos tipos, mas não foi claramente apresentado como fator de diferenciação. Os produtores enfatizaram a dotação de mão-de-obra e os técnicos enfatizaram a sua origem (familiar ou contratada), assim como procuraram incorporar o nível de renda na classificação. Os técnicos enfatizaram, ainda, aspectos de formação e gerenciais. Em ambas construções ressalta-se a importância da soja no valor da produção dos tipos com maiores recursos, concordando-se que esta cultura vem ganhando importância nos estabelecimentos menores. 


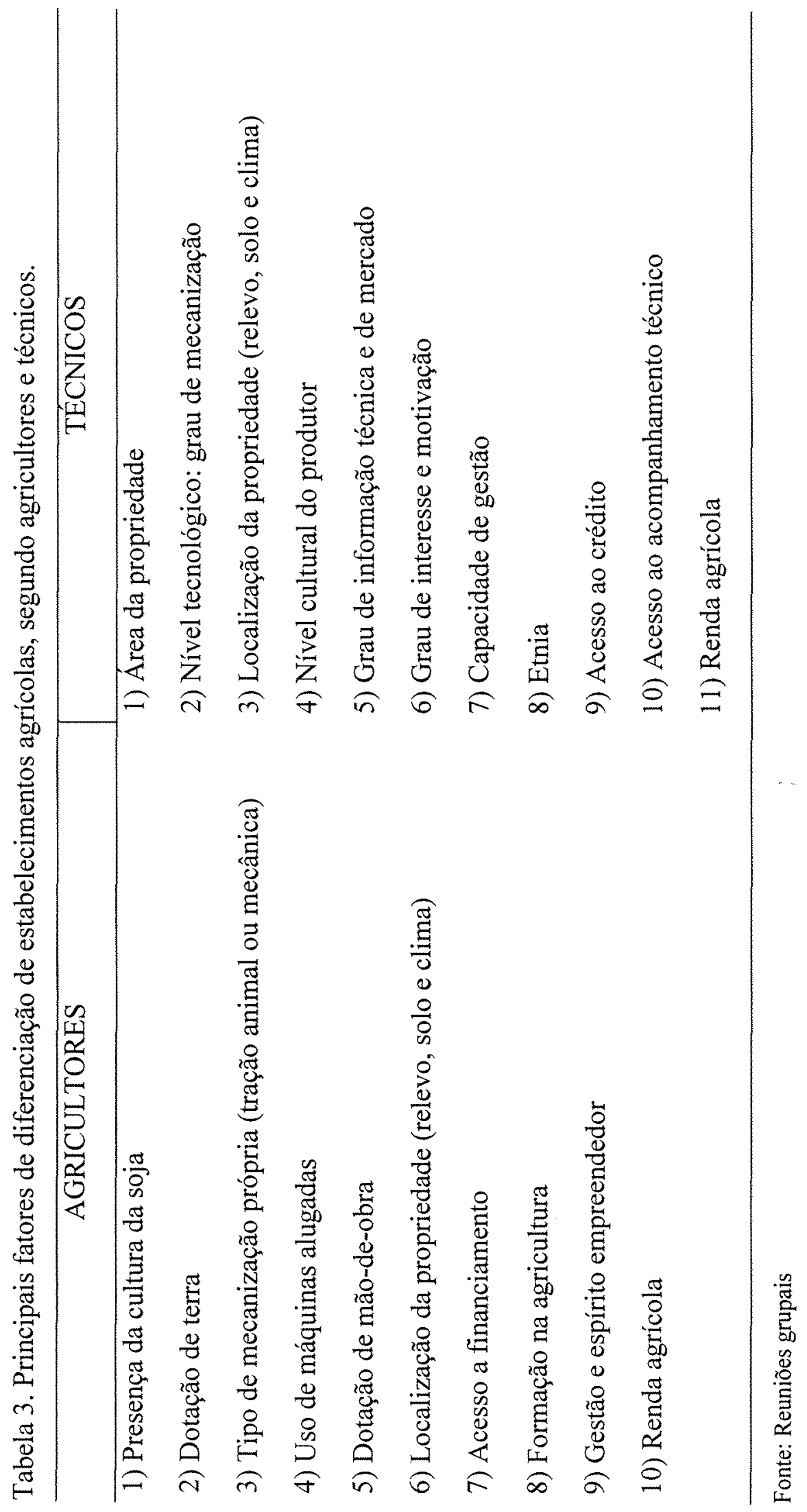




\subsection{Tipificação de produtores por amostragem de estabelecimentos}

Conforme já se mencionou, para a elaboração desta tipologia utilizou-se a base de dados referente a 34 entrevistas a propriedades localizadas na área de estudos no ano de 1997.

A partir dos resultados obtidos na etapa anterior, assumiu-se como pressuposto que os principais fatores condicionantes da adoção de planos alternativos de produção pelos agricultores dizem respeito à estrutura das propriedades, à formação/capacitação dos produtores e à possibilidade de acesso a crédito. Como na base de dados não se contava com informações acerca dos dois últimos fatores, foram as informações referentes à estrutura: área total, mão-de-obra familiar e capital material que embasaram a presente tipologia. Considera-se, portanto, que a potencialidade para o desenvolvimento tecnológico dessas unidades de produção esteja condicionada, de forma mais relevante, à sua dotação de recursos.

Para a classificação dos estabelecimentos empregou-se a análise fatorial por componentes principais, que permitiu extrair dois fatores, plotar as 34 propriedades em dois eixos ortogonais e identificar os tipos.

Posteriormente, para melhor descrever esses tipos, utilizaram-se as médias e desvios padrões referentes a 19 variáveis (indicadores) ${ }^{14}$, que refletem medidas da sua

${ }^{14}$ A base de dados disponível trazia a informação já agregada em vários indicadores de natureza econômica. Em seguida descrevem-se o método de cálculo dos indicadores que foram utilizados naquele trabalho. Várias informações, possivelmente levantadas nas entrevistas, não estavam presentes nessa base, como escolaridade, formação, uso de crédito agrícola, etc.

- Valor Agregado: calculado para cada atividade ou subsistema (que representa um conjunto de atividades interrelacionadas, como por exemplo: subsistema autoconsumo, subsistema soja/aveia), o valor agregado foi obtido subtraindo-se do produto bruto os custos com insumos e a depreciação. O Valor Agregado Total da propriedade (VAT) corresponde à soma dos valores agregados de cada atividade/subsistema;

- Capital: refere-se a máquinas, equipamentos e construções rurais;

- Área total: área sob administração direta do produtor, incluindo terrenos próprios e tomados em arrendamento; 
eficiência econômica: relação valor agregado de cada uma das atividades agropecuárias predominantes na amostra/valor agregado total da propriedade; relação valor agregado total da propriedade/unidade de trabalho total; relação valor agregado total da propriedade/unidade de trabalho familiar; relação valor agregado total da propriedade/capital; relação valor agregado total da propriedade/área total e relação valor agregado total da propriedade/custos totais de produção. Utilizaram-se, ainda, informações sobre as dotações de capital, mão-de-obra familiar, área total, renda agropecuária e outras rendas recebidas para caracterizar os tipos.

Os fundamentos da análise fatorial são descritos a seguir.

\subsubsection{Fundamentos da Análise Fatorial}

A análise fatorial faz parte da familia das análises multivariadas (Berdegué et al., 1990). A análise multivariada é a rigor qualquer abordagem analítica que considere o comportamento de muitas variáveis simultaneamente. As diversas técnicas de regressão múltipla são, nesse sentido, uma forma de análise multivariada. No entanto, há para o termo um stricto sensu que se refere a um conjunto de técnicas em particular, incluindo, entre elas, a Análise Fatorial (Pereira, 1999).

A análise fatorial é normalmente empregada quando se busca "resumir" uma grande quantidade de indicadores, representando-os através de um pequeno número de

- Unidade de Trabalho Familiar (UTF): 1 UTF corresponde a um adulto, membro da família, trabalhando 260 dias ao ano;

- Unidade de Trabalho Total: soma-se à mão-de-obra familiar a mão-de-obra contratada;

- Custos Totais: incluem custos dos estabelecimentos com insumos, depreciação, juros, impostos, trabalho contratado e taxa de arrendamento;

- Renda Agropecuária: ver nota de rodapé no. 6;

- Outras rendas: refere-se aos recursos provenientes de trabalho externo à propriedade como emprego de mão-de-obra como volante, prestação de serviços de máquinas, além de rendas oriundas de trabalho assalariado de membros da família, pensões, aposentadorias, etc. 
indicadores compostos, aos quais se atribui um significado. Busca-se, assim, facilitar a análise, reduzindo a dimensionalidade (número de variáveis) de um problema (Berdegué et al., 1990).

Nas ciências sociais e de comportamento, a análise fatorial permite desenvolver escalas para certas atribuições como atitudes, imagem, inteligência, personalidade, patriotismo, etc. O seu principal objetivo é, entretanto, explicar as razões para a existência de intercorrelações entre as variáveis (Sharma, 1996).

$\mathrm{Na}$ análise fatorial as variáveis (ou indicadores) refletem a presença de fatores (aos quais Sharma denomina "construções não observáveis"). Nas seguintes equações:

$$
\begin{aligned}
\mathrm{x}_{1}=\lambda_{11} \xi_{1}+\lambda_{12} \xi_{2}+\ldots . .+\lambda_{1 \mathrm{~m}} \xi_{\mathrm{m}}+\varepsilon_{1} \\
\mathrm{x}_{2}=\lambda_{21} \xi_{1}+\lambda_{22} \xi_{2}+\ldots . .+\lambda_{2 \mathrm{~m}} \xi_{\mathrm{m}}+\varepsilon_{2} \\
\\
\cdot \\
\cdot \\
\mathrm{x}_{\mathrm{p}}=\lambda_{\mathrm{p} 1} \xi_{1}+\lambda_{\mathrm{p} 2} \xi_{2}+\ldots . .+\lambda_{\mathrm{pm}} \xi_{\mathrm{m}}+\varepsilon_{\mathrm{p}}
\end{aligned}
$$

as variáveis $\mathrm{x}_{1}, \mathrm{x}_{2}, \ldots \mathrm{x}_{\mathrm{p}}$ são funções de fatores comuns $\xi_{1}, \xi_{2}, \ldots \xi_{\mathrm{m}}$ e de fatores específicos (relacionados a cada variável em particular), ou seja, $x_{1}, x_{2}, \ldots x_{p}$ refletem a presença desses fatores. Nessas equações, as intercorrelações entre as $p$ variáveis podem ser explicadas pelos $m$ fatores comuns, pois normalmente se assume que $m<p$. O número de fatores específicos é igual ao de variáveis.

Desta forma, a partir de uma matriz de correlação entre as variáveis pode-se, através da análise fatorial:

- Identificar os fatores comuns que são responsáveis pelas correlações entre as variáveis; 
- Estimar os coeficientes relacionados aos fatores comuns ("pattern loadings"), as comunalidades (ou a fração da variância de cada variável, devida aos fatores comuns) e as variâncias referentes aos fatores específicos relacionados a cada variável (variância específica ou erro).

Existem vários métodos para efetuar a análise fatorial. Os mais freqüentemente utilizados são o dos fatores principais e o dos componentes principais. Este último é o mais simples, e foi o empregado neste estudo. Os fatores são extraídos assumindo-se inicialmente que as comunalidades de todas as variáveis são iguais a um, ou seja, assume-se que o erro ou variância única é zero. Em seguida, a matriz de correlações com as comunalidades estimadas é submetida a uma análise de componentes principais. Os componentes principais podem ser representados por equações como as que se seguem:

$$
\begin{aligned}
\xi_{1}= & \omega_{11} x_{1}+\omega_{12} x_{2}+\ldots . .+\omega_{1 p} x_{p} \\
\xi_{2}= & \omega_{21} x_{1}+\omega_{22} x_{2}+\ldots . .+\omega_{2 p} x_{p} \\
& \cdot \\
& \cdot \\
& \cdot \\
\xi_{p} & =\omega_{p 1} x_{1}+\omega_{p 2} x_{2}+\ldots .+\omega_{p p} x_{p}
\end{aligned}
$$

onde $\xi_{1}, \xi_{2}, \ldots \xi_{\mathrm{p}}$ são os $p$ componentes principais e $\omega_{\mathrm{ij}}$ é o peso da jésima variável para o iésimo componente principal. Os pesos dos coeficientes $\omega_{\mathrm{ij}}$ são estimados de modo a que o primeiro componente principal extraia a máxima variância dos dados originais, o segundo a maior variância não captada pelo primeiro e assim por diante.

Os componentes principais são, portanto, combinações lineares das variáveis originais, constituindo-se em variáveis sintéticas, não correlacionadas entre si (Berdegué et al., 1990). 
A variância de cada componente principal é dada pela sua raiz característica, ou eigenvalue. Cada componente principal pode ser estandartizado para ter variância igual a um. Desta forma, as equações descritas em (10), podem ser reescritas de forma estandartizada, com as variáveis $\mathrm{x}_{1}, \mathrm{x}_{2}, \ldots \mathrm{x}_{\mathrm{p}}$ sendo agora representadas como funções dos componentes principais. Os coeficientes dos componentes principais dessas equações são reunidos numa matriz, a quem o pacote computacional SAS (Statistical Analysis System) ${ }^{15}$ chama "factor loadings", ou matriz de cargas fatoriais. Essa matriz representa, enfim, os coeficientes de correlação entre cada uma das variáveis analisadas e cada componente principal (ou fator) obtido. Cada fator, conforme já se mencionou, extrai uma parcela da variância do conjunto de dados, sendo ortogonais entre si.

Após a obtenção das raízes características e da matriz de cargas fatoriais, recomenda-se fazer a rotação dos fatores, mantendo-se a ortogonalidade entre os mesmos. Tal rotação fornece uma nova matriz de coeficientes, fazendo com que o valor do coeficiente de correlação do fator com cada variável se aproxime de zero ou um (correlação fraca ou forte), facilitando a interpretação do significado dos fatores (Sabbag, 2000). Neste estudo, empregou-se o método de rotação Varimax.

Finalmente, obtém-se a matriz que contém os valores de cada fator para cada observação (neste caso, para cada um dos 34 estabelecimentos agrícolas), valores que representam as projeções normalizadas dos pontos representativos dos estabelecimentos nos eixos dos fatores (Sabbag, 2000).

O processamento dos dados, utilizando a análise fatorial através do método dos componentes principais, foi realizado através do pacote computacional SAS.

\footnotetext{
${ }^{15}$ SAS é a marca registrada do SAS Institute Inc Cary, NC
} 
O confronto dos resultados obtidos nos grupos de produtores e técnicos com os alcançados na tipologia a partir da amostragem de estabelecimentos conduziu à escolha das propriedades a serem entrevistadas para levantamento dos coeficientes técnicos para a modelagem dos sistemas de produção.

\subsubsection{Tipologia de produtores de Boa Ventura de São Roque}

Conforme mencionado, agricultores e técnicos consideraram como principais fatores condicionantes à adoção de alternativas tecnológicas aqueles que dizem respeito à estrutura das propriedades, à formação/capacitação dos produtores e à possibilidade de acesso a crédito. Como a base de dados não disponibilizava informações acerca de todos esses fatores, foram considerados: área total, mão-deobra familiar e capital (máquinas e instalações) para a elaboração da presente tipologia. Uma vez definidos os tipos, tratou-se de caracterizá-los de forma breve, com base em 19 variáveis indicadoras de sua eficiência econômica, já anteriormente relacionadas.

Através da análise fatorial por componentes principais, aplicada às variáveis área total, capital e mão-de-obra familiar, obtiveram-se os resultados descritos a seguir.

A Tabela 4 mostra os fatores, as raízes características da matriz de correlações simples das variáveis, a porcentagem da variância relacionada a cada fator e a porcentagem de variância acumulada pelos diversos fatores. 
Pode-se verificar que os dois primeiros fatores captaram 99,05\% da variância total das variáveis originais, sendo que o fator 1 explica 74,85\% dessa variância.

Tabela 4. Raízes características (Eigenvalue), porcentagem da variância e porcentagem da variância acumulada. Tipologia de produtores de Boa Ventura de São Roque, Paraná.

\begin{tabular}{c|c|c|c}
\hline Fator & Eigenvalue & \% da Variância & $\begin{array}{c}\text { \% Variância } \\
\text { Acumulada }\end{array}$ \\
\hline 1 & 2,246 & 74,85 & 74,85 \\
2 & 0,726 & 24,20 & 99,05 \\
3 & 0,028 & 0,95 & 100,00 \\
Total & $3 *$ & 100 & 100,00 \\
\hline
\end{tabular}

Fonte: Bittencourt \& Bianchini (1997)

* ordem da matriz, ou, número de variáveis

Após a rotação dos fatores pelo método Varimax, objetivando sua melhor interpretação, obtiveram-se os resultados apresentados na Tabela 5 , que expressa os coeficientes de correlação (cargas fatoriais) entre cada variável e os fatores obtidos, as comunalidades e a porcentagem da variância explicada por cada fator, após a rotação. É interessante recordar que a comunalidade representa a fração da variância de cada variável explicada pelos fatores selecionados (no caso, dois fatores). 
Tabela 5. Coeficientes de correlação, comunalidades e porcentagem da variância explicada por cada fator após rotação (método Varimax). Tipologia de produtores de Boa Ventura de São Roque, Paraná.

\begin{tabular}{ccccc}
\hline Variável & Fator 1 & Fator 2 & Comunalidade \\
\hline Capital & 0,97 & 0,21 & 0,986 \\
$\begin{array}{c}\text { Mão-de-obra } \\
\text { familiar }\end{array}$ & 0,22 & 0,98 & 0,999 \\
Área total & 0,97 & & 0,986 \\
$\%$ da Variância & $64,25 \%$ & $34,80 \%$ & \\
\hline
\end{tabular}

Fonte: Bittencourt \& Bianchini (1997)

Observa-se que após a rotação o fator 1 apresentou correlação positiva e forte $(0,97)$ com as variáveis capital e área total, enquanto o fator 2 mostrou-se forte e positivamente correlacionado $(0,98)$ com a variável mão-de-obra familiar. É interessante ressaltar, ainda, que o total da variância explicada pelos dois fatores continua o mesmo, antes e após a rotação $(99,05 \%)$.

Com base nesses resultados, atribuiu-se ao fator 1 o significado "capital material" das explorações analisadas e ao fator 2, "mão-de-obra disponível".

Foi possível assim plotar as 34 propriedades em dois eixos ortogonais, onde $o$ fator 1 está representado no eixo das abscissas e o fator 2 no eixo das ordenadas. Para cada fator, o "corte" para a classificação dos diferentes grupos foi efetuado no ponto correspondente ao limite divisório entre valores acima e abaixo das médias (Figura 2). 


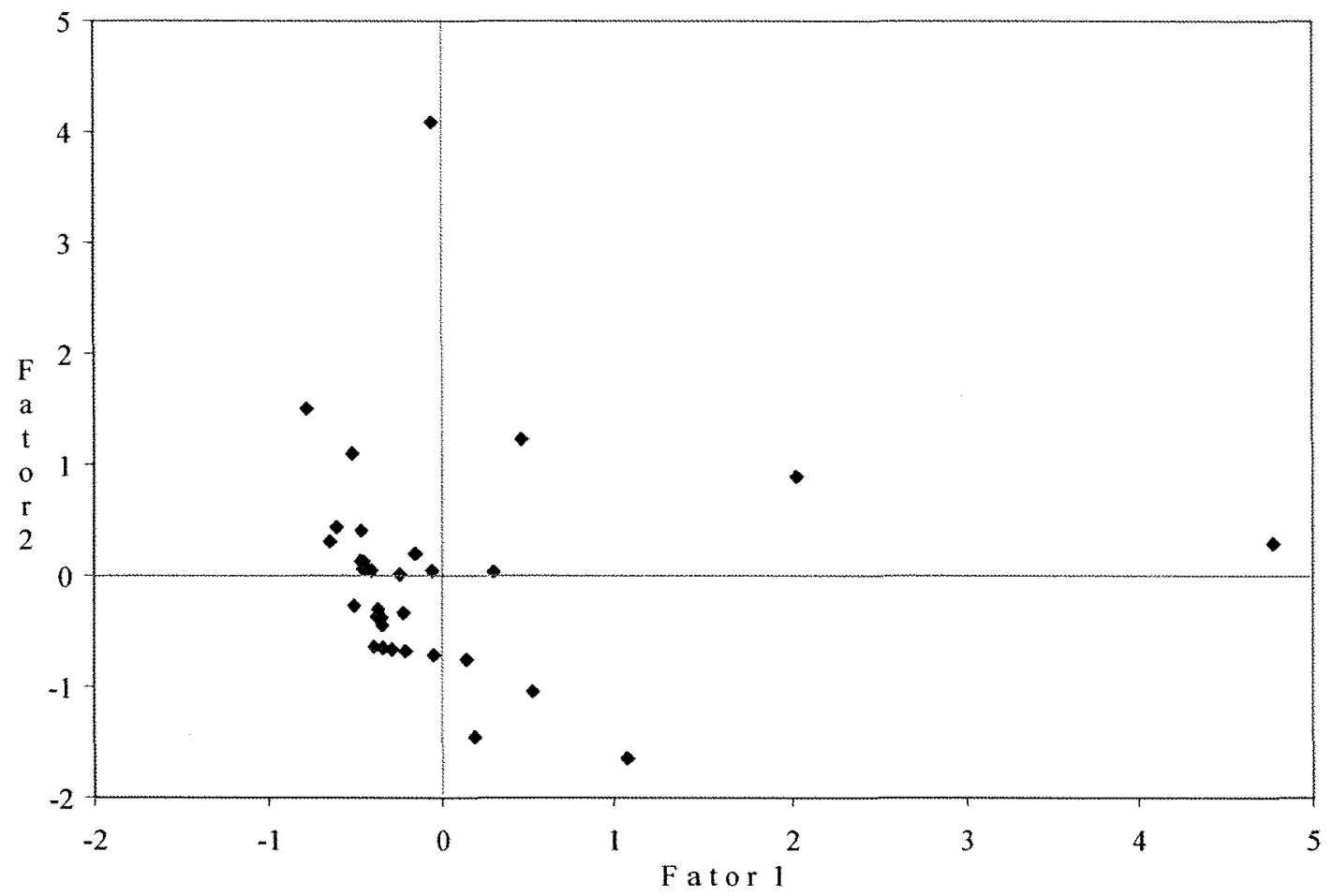

Figura 2 - Dispersão das propriedades segundo fator 1 (área e capital) e fator 2 (mãode-obra familiar).

Quatro grupos (ou tipos) foram, assim, formados. Os tipos I e II contêm os estabelecimentos com menores dotações de capital e terra (área total), sendo que o grupo I conta ainda, com as menores disponibilidades de mão-de-obra familiar. Os tipos III e IV incluem os estabelecimentos com maior dotação de capital e terra, tendo o tipo IV também a maior dotação de mão-de-obra familiar.

Para cada um destes tipos fez-se uma análise das médias e desvios padrões das variáveis abaixo apresentadas, buscando melhor caracterizá-los. Os resultados são apresentados na Tabela 6 . As variáveis usadas na caracterização dos tipos foram:

1) $\mathrm{VASO} / \mathrm{VAT}=$ Valor agregado da soja/valor agregado total

2) $\mathrm{VAMI} / \mathrm{VAT}=$ Valor agregado do milho/valor agregado total 
3) $\mathrm{VABOV/VAT}=$ Valor agregado da bovinocultura (leite e carne)/valor agregado total

4) $\mathrm{VAFE} / \mathrm{VAT}=$ Valor agregado do feijão/valor agregado total

5) VASU/VAT $=$ Valor agregado da suinocultura/valor agregado total

6) $\mathrm{VAFU} / \mathrm{VAT}=$ Valor agregado do fumo/valor agregado total

7) $\mathrm{VAER} / \mathrm{VAT}=$ Valor agregado da erva-mate/valor agregado total

8) VAAUT/VAT = Valor agregado do autoconsumo/valor agregado total

9) VAOUT/VAT = Valor agregado de outras atividades/valor agregado total

10) VAT/UTT = Valor agregado total/unidade de trabalho total $(\mathrm{R} \$ / \mathrm{UTH})$

11) $\mathrm{VAT} / \mathrm{UTF}=$ Valor agregado total/unidade de trabalho familiar $(\mathrm{R} \$ / \mathrm{UTH})$

12) $\mathrm{VAT} / \mathrm{CAP}=$ Valor agregado total/capital

13) $\mathrm{VAT} / \mathrm{AREA}=$ Valor agregado total/área total $(\mathrm{R} \$$ /alq $)$

14) $\mathrm{VAT} / \mathrm{CUSTO}=$ Valor agregado total/custo total

15) CAPITAL = Valor do capital (R\$)

16) MDO FAM = Mão-de-obra familiar (UTF)

17) AREA TOT $=$ Área total (alq)

18) RENDA AGR = Renda agropecuária $(\mathrm{R} \$)$

19) OUT RENDA = Outras rendas (R\$) 


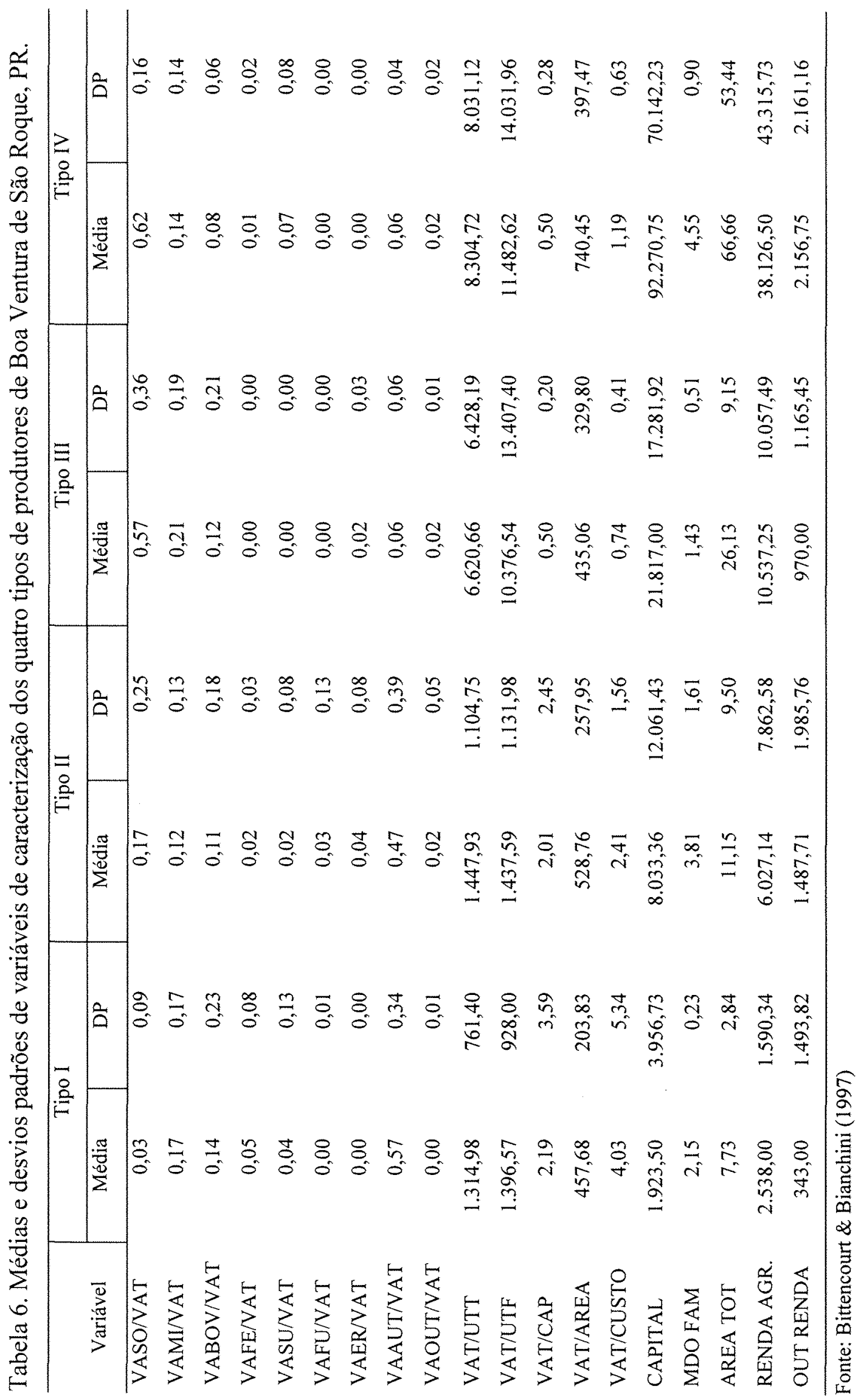


A área média dos estabelecimentos do tipo I, que conta com doze integrantes, é próxima aos $8 \mathrm{alq}^{16}$, eles dispõem em média de 2,15 UTH na família e menos de $\mathrm{R} \$ 2.000,00$ de capital. A renda oriunda da agropecuária gira em torno de $\mathrm{R} \$ 2.500,00$ ao ano e recebem em média $\mathrm{R} \$ 343,00 /$ ano oriundos de outras rendas. No tipo I apenas um estabelecimento cultiva soja. Ela contribui com cerca de 3\% ao Valor Agregado Total (VAT) dos estabelecimentos do grupo. Neste tipo, a produção para autoconsumo representa o maior peso na formação do VAT das propriedades, com cerca de $57 \%$. Segue-lhe o milho destinado à comercialização, que contribui com cerca de $17 \%$ ao VAT dos estabelecimentos. A pecuária bovina vem em seguida, com cerca de $14 \%$ do VAT. O feijão destinado ao mercado representa somente cerca de $5 \%$ do VAT para este grupo de produtores. Existe um caso de produção de fumo, que praticamente não contribuiu para o total do valor agregado do grupo (menos de $0,5 \%$ ). Aqui se observam as menores médias de valores agregados por unidade de trabalho familiar e total, o que estaria indicando um baixo retorno à mão-de-obra utilizada. Por outro lado, os Valores Agregados por unidade de capital e de custo de produção são os mais altos, o que deve revelar os baixos níveis de investimentos realizados na produção. Já a média do Valor Agregado por unidade de área é mais alta que a média do mesmo indicador para o tipo III . Sete dos doze integrantes deste grupo são beneficiários da Reforma Agrária. Ao tipo I corresponderiam os produtores de subsistência ou produtores simples de mercadoria, segundo a tipologia definida pelo IAPAR para o estado do Paraná (Man Yu \& Sereia, 1993; Guerreiro, 1995).

O tipo II reúne quatorze estabelecimentos, que têm área média de 11 alq, capital de produção médio próximo aos $\mathrm{R} \$ 8.000,00$ e renda agropecuária média anual de aproximadamente $\mathrm{R} \$ 6.000,00$. Recebem de outras fontes cerca de $\mathrm{R} \$ 1.500,00$ ao ano. As famílias dispõem em média de 3,8 UTH. Neste grupo a soja contribui com cerca de $17 \%$ na formação do VAT das propriedades, sendo superada apenas pela produção de autoconsumo, que representa cerca de $47 \%$ do VAT. Seguem em importância o milho

\footnotetext{
${ }^{16} \mathrm{Alq}=$ alqueire, unidade de medida de área utilizada na região de estudo, que corresponde a 2,42 ha.
} 
destinado à venda com cerca de $12 \%$, a pecuária bovina com $11 \%$, o fumo e a erva mate, estes com menos de $4 \%$ cada um. Feijão e suínos para comercialização representam, individualmente, cerca de $2 \%$ do VAT dos estabelecimentos. Neste grupo, os valores agregados por unidade de trabalho e por unidade de capital são próximos ao grupo anterior. $\mathrm{O}$ valor agregado por área é aqui superior ao grupo anterior, perdendo apenas para o tipo IV. O valor agregado por custo de produção cai significativamente, em relação ao tipo I. O tipo II corresponderia aos produtores simples de mercadoria da classificação do IAPAR.

No tipo III, com quatro representantes, a área média das unidades produtoras é de 26 alq, o capital gira em torno de $R \$ 22.000,00$ e a renda agropecuária em torno de $\mathrm{R} \$ 10.500,00 /$ ano. Recebem como outras rendas uma média de $\mathrm{R} \$ 970,00$. As famílias possuem uma força de trabalho equivalente a 1,42 UTH. A soja representa cerca de $57 \%$ do VAT, seguida do milho e da pecuária bovina, com respectivamente, 21 e $12 \%$. O autoconsumo representa cerca de $6 \%$ do VAT e a erva mate cerca de $2 \%$. É inexpressiva a participação do feijão destinado à comercialização no VAT dos estabelecimentos deste grupo. O valor agregado por unidade de mão de obra, embora alto, é inferior ao tipo IV, e os indicadores de valor agregado por área total, capital e custo total são os menores entre todos os grupos. Neste grupo poderiam estar incluídos os tipos de produtores empresários familiares ou empresários rurais, da classificação do IAPAR, conforme o nível de contratação de mão-de-obra em que incorram.

No tipo IV os estabelecimentos (em número de quatro) detêm uma área média de 67 alq, um capital médio de $\mathrm{R} \$ 92.000,00$, obtendo uma renda agropecuária média anual próxima aos $\mathrm{R} \$ 38.000,00$. Cerca de $\mathrm{R} \$ 2.000,00$ ao ano provêm de outras rendas. A família dispõe como mão-de-obra de 4,5 UTH. São estabelecimentos aparentemente menos diversificados, com a soja representando acima de $60 \%$ do VAT. Em seguida aparecem o milho destinado à comercialização, com $14 \%$ e a pecuária bovina com $8 \%$. $\mathrm{O}$ autoconsumo representa cerca de $6 \%$ do VAT e a produção de suínos com fins comerciais, $7 \%$. Feijão com destino comercial não atinge $1 \%$ do VAT. Neste grupo são 
obtidas as maiores médias de valor agregado por unidade de trabalho, superando os R\$ $8.000,00$ por unidade de trabalho total/ano. O valor agregado por unidade de área é o mais alto de todos, devendo indicar melhor nível tecnológico. O valor agregado por unidade de capital e de custo total mostra uma queda importante em relação aos tipos anteriores, especialmente o valor agregado por unidade de capital, que deve refletir o alto valor do capital investido em máquinas e equipamentos agrícolas, notadamente de plantio direto. Corresponderia aos tipos de produtores empresários familiares ou empresários rurais, da classificação do IAPAR, conforme o nível de contratação de mãode-obra que efetuem.

Deve-se chamar a atenção, entretanto, para o fato dos desvios padrões mostrarem-se bastante altos, na maioria dos casos. Apesar da cautela com que devem ser tratadas as conclusões oriundas de tais informações, elas estariam sendo validadas (ou estariam validando) os resultados das tipologias construídas pelos agricultores e técnicos.

\subsubsection{Escolha das propriedades para modelagem}

Foram entrevistados 10 produtores, sendo 2 ou 3 estabelecimentos representantes de cada um dos quatro tipos descritos no ítem anterior, para a construção dos coeficientes técnicos que embasaram a modelagem matemática.

Desta amostra, duas propriedades foram escolhidas, uma do tipo I e outra do tipo IV, ou seja, os estabelecimentos com menor e maior dotação dos recursos terra, mão-deobra e capital, em seu conjunto. Considerou-se que a presença da cultura da soja nesses dois tipos extremos poderia conduzir a interessantes análises no sentido de se entender a lógica e os resultados econômicos oriundos desses sistemas de produção. 
Convém destacar, utilizando dados do censo agropecuário de 1995/96, a representatividade de diferentes grupos de área cultivada com a cultura da soja nos estabelecimentos do Paraná e do município de Pitanga, que nessa época abarcava a área de estudos. As médias paranaenses mostravam que cerca de $46 \%$ das propriedades que produziam soja no estado o faziam em áreas inferiores a 20 ha; nos grupos de área cultivada com soja menores que 10 ha estavam contidos cerca de $20 \%$ dos informantes; no estrato entre 20 e 50 ha de área cultivada com soja concentravam-se $31 \%$ dos estabelecimentos, sendo a classe mais representativa do estado em termos de produção; áreas cultivadas superiores a 50 ha ocorriam em cerca de $23 \%$ dos estabelecimentos. Para o municípo de Pitanga, a situação se invertia: embora se mantivesse a mesma porcentagem de estabelecimentos (31\%) na faixa entre 20 e 50 ha, os grupos com menos de 20 ha representavam cerca de $27 \%$ dos informantes e aqueles que cultivavam área de soja superior a 50 ha, $41 \%$. Em Pitanga, portanto, por ocasião do último censo, a cultura da soja era implementada prioritariamente nos estabelecimentos de porte médio e grande para o município.

Os dados descritos anteriormente corroboram as informações prestadas por agricultores e técnicos locais no momento em que se construiu a tipologia. Entretanto, técnicos e produtores percebem, nos últimos anos, uma tendência de ampliação da entrada da soja em estabelecimentos muito pequenos na área de estudos, especialmente entre agricultores jovens, dada a possibilidade de contratação do serviço de máquinas e a crescente queda na rentabilidade de culturas como milho e feijão nos moldes tecnológicos praticados pelos pequenos produtores. Esse é um fato que os preocupa, pois consideram inviável a produção de soja em pequenas superfícies. Interessa-lhes um estudo mais aprofundado sobre o assunto para orientar um posicionamento em relação a essa tendência. Esta situação influenciou na escolha da pequena propriedade em que a soja participava da combinação de atividades em uso pelo produtor. 
Adicionalmente, a escolha levou em consideração a qualidade da informação: a análise dos dados desses estabelecimentos permitiu a construção de coeficientes considerados bastante coerentes. 


\section{METODOLOGIA PARA MODELAGEM DE SISTEMAS DE PRODUÇÃO}

\subsection{Bases de dados}

As informações que serviram de base para a modelagem dos sistemas de produção foram recolhidas através de entrevistas aos produtores, havendo sido utilizado um roteiro preestabelecido e considerado o ano agrícola 2000/2001. Dados referentes a preços de insumos foram obtidos junto à COAMO, e se referem aos preços praticados em setembro de 2000 na área de estudos. As informações utilizadas para a estimativa de produtividades e preços esperados foram obtidas de séries históricas do DERAL/PR ${ }^{17}$ para o período 1990/2000, e se referem a médias do estado. Os valores nominais das séries de preços foram transformados em valores reais de julho de 2001 pelo IGPDI/FGV. Convém esclarecer que ao utilizar as médias estaduais de preços, as receitas dos produtores podem estar sendo subestimadas, uma vez que para a região de Guarapuava as médias de preços são normalmente superiores às médias estaduais, especialmente para as principais culturas consideradas. As séries históricas de precipitação pluvial para cálculo do número de dias úteis de máquinas agrícolas foram fornecidas pelo Instituto Tecnológico SIMEPAR. Indicadores técnicos referentes à disponibilidade e uso de forrageiras, carga animal, máquinas agrícolas e mão-de-obra foram confirmados junto a especialistas. A definição da função objetivo e das restrições procurou abarcar a lógica dos sistemas. Sua essência foi discutida com produtores e especialistas de diferentes áreas, sendo sua construção um processo gradual baseado no

\footnotetext{
${ }^{17}$ Departamento de Economia Rural da Secretaria da Agricultura do Paraná.
} 
avanço da análise dos dados. As fronteiras eficientes das propriedades foram geradas a partir do MOTAD, havendo sido localizados os sistemas atuais nessas fronteiras em função das margens brutas das propriedades e da soma de seus desvios negativos em relação às tendências de receitas esperadas (proxy para o risco). Para estimar os desvios foram utilizadas séries históricas do DERAL/PR referentes a preços, produções e áreas dos diferentes produtos e séries de salários pagos à mão-de-obra volante, referentes a médias mensais estaduais no período 1990/2000. Optou-se por utilizar as médias mensais de preços (e não as médias nos momentos de comercialização), pelo fato de haver-se observado que, na prática, os produtores vendem seus produtos, especialmente grãos como soja e milho, em diversos períodos do ano, para fazer frente às suas necessidades de caixa e esperando bons preços, mantendo-os armazenados na cooperativa. Alguns cenários foram simulados no processo de construção dos modelos. Estes passos são descritos a seguir mais detalhadamente.

\subsection{Formulação dos modelos deterministas}

Primeiramente desenvolveu-se um modelo determinista (sem consideração de risco) através de Programação Linear, para cada tipo de estabelecimento, cujo objetivo era maximizar as margens brutas ${ }^{18}$ considerando o conjunto das atividades realizadas nas propriedades. Mantiveram-se, nestes modelos, os padrões tecnológicos adotados pelos produtores para cada atividade agropecuária. Para o cálculo das margens brutas das atividades estimaram-se os preços esperados para o último ano das tendências no período 1990/2000. O modelo convencional de programação linear pressupõe, portanto,

\footnotetext{
${ }^{18}$ A margem bruta de uma atividade corresponde ao valor bruto da produção da atividade, subtraído dos custos com insumos (inclusive óleo diesel e lubrificantes), manutenção e seguro de máquinas. A margem bruta corresponde, portanto, a remuneração aos fatores fixos (terra, trabalho, capital e recurso empresarial). Os cálculos de consumo das máquinas foram feitos considerando que as mesmas estivessem operando a 50 e $90 \%$ de suas potências, conforme as operações culturais realizadas, de acordo com as curvas características de desempenho de tratores encontradas em Mialhe (1974) e catálogos dos fabricantes de tratores. Tais cálculos tiveram por base as descrições feitas pelos produtores acerca do tempo gasto por operação.
} 
que os agricultores baseiam sua expectativa de preços futuros em suas experiências passadas, baseados nas tendências lineares de preços.

Como as atividades competem pelos recursos dos estabelecimentos, consideraram-se como restrições as disponibilidades de terra, capital, mão-de-obra familiar e máquinas agrícolas. As restrições contemplam, ainda, parâmetros referentes ao padrão técnico das propriedades e ao comportamento dos produtores, condicionantes da produção.

A descrição detalhada das atividades e das restrições consideradas para cada tipo de produtor será feita na seção de resultados da modelagem dos sistemas de produção.

Utilizou-se o software Lindo, versão 6.1, para operacionalizar o problema de maximização.

\subsection{Formulação dos modelos em condições de risco}

O modelo MOTAD, usado para introduzir o risco no modelo convencional de Programação Linear, foi especificado no ítem 3.3 desta dissertação. O problema consiste na minimização dos desvios absolutos, medidos em relação às margens brutas esperadas, sendo esses desvios uma medida de risco. Esses desvios representam o somatório das variações anuais em relação às receitas esperadas, devidas a variações nos preços (que representariam riscos de mercado) e produtividades (riscos climáticos).

Conforme se mencionou no ítem 3.3, nesta dissertação partiu-se do pressuposto que os produtores são capazes de visualizar tendências lineares de variações de preços e produtividades das culturas, e que consideram tais tendências no momento de planejar o seu conjunto de atividades produtivas. Assim, para estimar os desvios em relação aos valores esperados pelos produtores, foram definidas regressões lineares considerando 
uma variável de tendência para preços recebidos, produtividades e receitas (preço $\mathrm{x}$ produtividade) para as atividades dos estabelecimentos analisados, de acordo com o significado das variáveis de decisão integrantes da função objetivo. Os resíduos dessas regressões constituíram os desvios utilizados na formulação do modelo MOTAD. Assim, para as atividades soja, trigo, arroz e feijão, os desvios foram calculados em relação à tendência das receitas. No caso do produtor do tipo IV previu-se para as atividades milho e triticale o balanço entre venda e consumo na produção de leite. Cada uma dessas culturas foi, então, identificada por uma variável referente à produção (contemplando os custos de produção) e outra referente à venda do produto (contemplando o preço esperado). Os desvios para estas atividades foram, portanto, calculados em relação à tendência de produtividade e preço, separadamente. Quando as séries de alguma atividade não possibilitavam uma medida adequada da produtividade nos moldes do estudo (todas as produtividades estão aqui expressas em função da área física), usaram-se os seguintes critérios: para as atividades pecuária de leite, pecuária de corte e erva mate foram admitidas produtividades físicas constantes (as atuais produtividades dos agricultores) e os desvios foram calculados somente em relação aos preços. Para a atividade venda de mão-de-obra os desvios foram calculados em relação à tendência dos salários pagos pelas diárias.

Conforme já se mencionou anteriormente, o modelo pressupõe risco somente do lado do produto. Parte-se do pressuposto que, no início do ano agrícola, o produtor conhece os preços dos insumos que vai utilizar em sua produção, mas não sabe de antemão os preços e produtividades que vai alcançar, percebendo apenas as tendências dos mesmos.

Deve-se esclarecer que o modelo não inclui a possibilidade de uso de seguro agrícola, cuja utilização poderia alterar os resultados uma vez que se cobririam as perdas por redução na produtividade. Entretanto, dado seu alto custo, especialmente para a cultura do trigo, o seguro agrícola é pouco utilizado no Brasil, não fazendo parte das estratégias adotadas nos sistemas de produção analisados nesta dissertação. 


\subsection{Determinação da fronteira eficiente e do coeficiente de aversão ao risco dos produtores}

Para gerar a fronteira eficiente, o problema de minimização dos desvios anteriormente descrito é formulado parametrizando-se o valor de margens brutas esperadas de zero até o valor máximo obtido com o modelo convencional de programação linear.

Obtém-se uma curva (ou uma série de segmentos de reta) que representa o risco envolvido (representado pelos desvios, no eixo das abscissas), para a obtenção de certo nível de margem bruta (representado no eixo das ordenadas). Trata-se de uma fronteira (fronteira eficiente) que pode ser considerada como um "padrão", em função do qual pode ser medida a eficiência das firmas analisadas. Desvios em relação a essa fronteira poderiam ser considerados como ineficiências. Assim, o nível de eficiência dos sistemas de produção atualmente praticados poderia ser medido a partir da sua distância em relação à fronteira eficiente. Peres (1976) admite, entretanto, que o fato do agricultor operar em um ponto abaixo de sua fronteira eficiente pode estar relacionado ao fato de que nem todas as suas características comportamentais são abarcadas pelo modelo (por exemplo, a produção de subsistência) ou por não se incorporar alguma informação relevante.

No conceito de fronteira eficiente proposta por Markowitz, o plano de produção preferido seria aquele que maximizasse a utilidade do produtor, o que ocorreria no ponto onde a sua curva de indiferença tangenciasse a fronteira eficiente. Para Peres (1981), as fronteiras eficientes são calculadas sem a utilização de informações sobre o grau de aversão ao risco dos agricultores. Para a autora, a determinação de pontos de equilíbrio depende de pressuposições sobre a forma explícita das curvas de utilidade dos agricultores, o que considera um objetivo muito difícil, se não impossível, de ser alcançado. 
Para estimar o grau de aversão ao risco dos produtores, Peres (1976) busca o ponto da fronteira eficiente que minimiza a distância ao ponto que representa o seu sistema atual. A propriedade representativa é identificada através do nível correspondente de variância e de retorno esperado, dado o mix atual de atividades dessa propriedade. $\mathrm{O}$ autor, entretanto, chama a atenção para o fato de que esta é uma decisão arbitrária, fruto da não observação, na prática, da hipótese inicial que as combinações de atividades das unidades representativas estão na fronteira eficiente. A não localização dos sistemas atuais nas fronteiras pode estar ligada, conforme se discutirá mais adiante, a dificuldades na completa reprodução do comportamento dos agricultores através do modelo. Peres pressupõe, ainda, que a tangente à curva de indiferença do produtor é uma linha reta que passa pelo ponto representativo do sistema de produção na fronteira eficiente. Para produtores aversos ao risco, a curva de indiferença possui inclinação positiva no espaço retorno-risco. A tangente da fronteira eficiente no ponto representativo do sistema de produção corresponde à "taxa marginal de substituição" entre risco e retorno, e equivale ao coeficiente de aversão ao risco do produtor.

Conforme se mencionou anteriormente, nesta dissertação a definição do ponto representativo do sistema em uso se fez em função da margem bruta da propriedade (que corresponde ao somatório das margens brutas das atividades, descontados as despesas referentes ao autoconsumo e ao pagamento das obrigações creditícias) e da soma de seus desvios negativos em relação às receitas esperadas. Considerou-se, então, o ponto na fronteira que tem a menor distância em relação ao sistema atual. O coeficiente de aversão ao risco dos produtores corresponde à inclinação da curva nesse ponto. 


\subsection{Análises de sensibilidade}

O estudo inclui a discussão dos resultados das análises de sensibilidade de modelos deterministas para alguns cenários referentes aos sistemas de produção analisados. Tal discussão contempla:

- A análise das restrições através do valor dual (ou preço-sombra) que mostra os pesos relativos de cada restrição, logo, os pontos de estrangulamento mais importantes dentro de cada sistema de produção;

- A análise de sensibilidade do RHS (Right Hand Side), ou seja, dos valores disponíveis de recursos apresentados nas restrições;

- A análise de sensibilidade dos coeficientes da função objetivo, que pode adiantar algo a respeito do nível de incerteza de tais coeficientes. 


\section{RESUltados E DISCUSSÃO DA MODELAGEM DE SISTEMAS DE PRODUÇÃO}

\subsection{Sistema de produção da propriedade tipo IV}

\subsubsection{Características da exploração}

A propriedade tipo IV é um exemplo de associação familiar: dois irmãos conduzem a exploração agrícola de 160 alq de terras próprias. As máquinas e equipamentos, as benfeitorias e rebanhos são de propriedade comum. A gestão da propriedade, assim como decisões sobre investimentos também se fazem de maneira conjunta. Desta forma, os produtores podem manter uma escala de produção que não seria possível caso dividissem seus bens. Trata-se de uma propriedade de bom porte para a região, que tem conseguido capitalizar-se através da compra de terras e de máquinas.

A mão-de-obra empregada é essencialmente familiar, realizando-se apenas contratações esporádicas de mão-de-obra externa em momentos de pico de trabalho. São dez pessoas residentes na propriedade (cinco membros de cada família), sendo calculada uma disponibilidade de 5,4 UTH.

A propriedade tem como carro chefe a produção de grãos, obtendo muito boa produtividade com as culturas da soja e do milho; a soja ocupa a maior parte da área produtiva da propriedade. Também se produz leite e carne, aproveitando a cobertura de inverno (aveia e azevém) das áreas de soja. Mantêm-se as atividades de cria e venda de bois magros. A produção forrageira no verão está condicionada às áreas sem aptidão 
agrícola da propriedade e se constitui na principal limitação à expansão das atividades pecuárias. A produção de erva-mate se dá em ervais sob mata nativa. Também se produzem culturas visando principalmente o autoconsumo, como trigo, arroz, feijão, hortaliças, frutas e pequenos animais.

A propriedade conta com um capital avaliado em $\mathrm{R} \$ 178.500,00$, concernente aos seguintes recursos de mecanização: dois tratores (75 e $83 \mathrm{CV}$ ), uma colheitadeira com plataformas para soja e milho, uma semeadeira e uma plantadeira para plantio direto, duas carretas, dois pulverizadores, uma adubadeira, uma batedeira automotriz, um caminhão, além de implementos de preparo e plantio convencional como grade de disco, arado, subsolador, etc. Emprega-se o plantio direto e a colheita mecanizada nas principais atividades agrícolas.

Os produtores, questionados sobre suas aspirações com relação ao seu sistema de produção, manifestaram que gostariam de se dedicar mais à produção animal, especificamente à produção de suínos (transformando o milho em carne) e engorda de bovinos. Em outras palavras, gostariam de diversificar ainda mais. Entretanto, vêem-se limitados pelas más condições das estradas que conduzem à propriedade, que no inverno muitas vezes se tornam intrafegáveis. A produção de leite enfrenta hoje o mesmo problema: por vezes o caminhão de coleta não consegue chegar e os produtores são obrigados a armazenar, em condições precárias, a produção de vários dias, incorrendo não poucas vezes em perda do produto. Outra limitação apontada para a implementação das mencionadas alternativas produtivas é a conseqüente necessidade de contratação de empregados permanentes, fato considerado oneroso pelos encargos sociais que representa. O nível de escolaridade dos produtores é baixo (cursaram somente até a terceira série do ensino básico), no entanto eles manifestaram a aspiração de que todos os filhos estudem, apesar de reconhecerem a grande dificuldade que enfrentam os jovens do campo para prosseguirem seus estudos. Aliam-se às duras jornadas de trabalho (especialmente nos períodos de plantio e colheita), o problema do transporte e a má qualidade do ensino no meio rural. 
Os produtores contam com a assessoria técnica da COAMO, em especial para as culturas da soja e do milho. Utilizam rotineiramente crédito rural para o custeio da lavoura de soja e recentemente utilizaram financiamentos para a aquisição de máquinas agrícolas (trator e plantadeira) e para a correção dos níveis de fósforo da propriedade. Apesar do bom porte do estabelecimento, não se realizam registros de nenhum tipo, o que de algum modo dificultou a coleta de dados, embora os produtores tivessem bastante presentes os resultados das atividades e tenham dado informações que conduziram a coeficientes técnicos coerentes.

\subsubsection{Modelo determinista para a propriedade tipo IV: atividades, restrições, função objetivo e análises de sensibilidade}

A função objetivo corresponde ao produto das margens brutas pelos níveis de cada atividade. Nela estão incluídas as receitas advindas de cada atividade, as transferências de capital a uma taxa de juros de $0,5 \%$ ao mês (elementos com sinais positivos) e as despesas, referentes a gastos com autoconsumo, contratação de mão-deobra, pagamentos de créditos e compras de insumos nos casos das culturas do milho e triticale (elementos com sinais negativos).

As atividades consideradas para a definição do modelo de Programação Linear convencional da propriedade do tipo IV foram as seguintes:

$\mathrm{SO}=$ Atividade soja, inteiramente destinada ao mercado. Utilizando o plantio direto e colheita mecânica, obtém-se um rendimento de $132 \mathrm{sc} 60 \mathrm{Kg} / \mathrm{alq}$, que gera, a um preço esperado de $\mathrm{R} \$ 17,67 / \mathrm{sc}$, uma margem bruta de $\mathrm{R} \$ 1.121,59 / \mathrm{alq}$. A soja ocupa os solos de novembro a abril. A esta atividade está associada a cobertura invernal de aveia e azevém, fato que a vincula aos rebanhos de leite e carne. Obtém-se uma produção anual média de $9.680 \mathrm{~kg}$ de matéria seca de forragem no período de abril a setembro; 
SONA = Atividade soja, não associada à cobertura invernal de aveia e azevém. Utiliza plantio direto e colheita mecânica e ocupa o solo de novembro a abril, o que possibilita a rotação com trigo e triticale. Como se excluem os custos com a cobertura invernal, esta atividade propicia uma margem bruta de $\mathrm{R} \$ 1.170,49 /$ alq.

$\mathrm{TG}=$ Atividade trigo, destinada ao consumo da família e ao mercado. Alcança rendimento de $110 \mathrm{sc} / \mathrm{alq}$, gerando uma margem bruta de $\mathrm{R} \$ 812,36 /$ alq ao se considerar o preço esperado de $\mathrm{R} \$ 12,60 / \mathrm{sc}$. Ocupa o solo de maio a outubro, utilizando plantio direto e colheita mecanizada.

PROTC $=$ Corresponde aos custos de produção da atividade triticale $(\mathrm{R} \$ 139,15 / \mathrm{alq})$, que conduzem a uma produtividade física de $65 \mathrm{sc} / \mathrm{alq}$. Esta atividade é destinada à alimentação animal e ao mercado ${ }^{19}$. Utiliza plantio direto e colheita mecanizada.

$\mathrm{VTC}=$ Corresponde ao preço esperado com a atividade de venda de triticale: $\mathrm{R} \$ 7,59 / \mathrm{sc}$ de $60 \mathrm{Kg}$

PROMI $=$ Corresponde aos custos de produção da atividade milho $(\mathrm{R} \$ 2.078,70 / \mathrm{alq})$, que conduzem a uma produtividade física de 415 sc/alq. Esta atividade também está vinculada à produção animal e ao mercado. É produzida no sistema de plantio direto e utiliza colheita mecanizada.

$\mathrm{VM}=$ Corresponde ao preço esperado por saca de milho: $\mathrm{R} \$ 8,64 / \mathrm{sc}$ de $60 \mathrm{Kg}$.

PAVE = Atividade de produção de pastagens de verão, da espécie Hemarthria altíssima, obtendo-se uma produção de $10.890 \mathrm{Kg}$ de matéria seca por alqueire/ano, a um custo de $\mathrm{R} \$ 189,49$ /alq.

$\mathrm{LE}=$ Corresponde à atividade leiteira, que gera uma margem bruta de $\mathrm{R} \$ 1.035,65 / \mathrm{alq}$, obtido a partir da produção de leite e carne de um rebanho leiteiro de $30,25 \mathrm{UA}^{20}$, com 20 vacas leiteiras, rendimento médio de 1.160 litros/vaca/ano e um preço esperado de $R \$$ 0,28/litro. Utiliza-se ordenha manual.

\footnotetext{
${ }^{19}$ As atividades milho e triticale são destinadas tanto ao mercado quanto ao consumo do rebanho leiteiro na propriedade. Conforme já se mencionou anteriormente, por estarem vinculadas a outra atividade produtiva e ao mercado, elas foram divididas em produção e venda. A diferença entre produção e venda corresponde à parcela destinada ao rebanho.

${ }^{20} 1 \mathrm{UA}$ corresponde a uma vaca de $450 \mathrm{Kg}$
} 
$\mathrm{CA}=$ Corresponde à atividade de cria e recria de bovinos, que proporciona uma margem bruta de $\mathrm{R} \$ 900,12 /$ alq, advinda de um rebanho médio de 77 UA. O preço esperado foi $\mathrm{R} \$ 345,74 /$ animal de $300 \mathrm{Kg}$.

$\mathrm{FE}=$ Corresponde à atividade feijão, a partir da qual obtém-se uma margem bruta de $\mathrm{R} \$ 1.021,85 / \mathrm{alq}$, com um rendimento de 36,53 sc/alq e um preço esperado de $\mathrm{R} \$$ $42,69 /$ sc. O preparo de solo é mecanizado convencional, enquanto o plantio, as capinas e a colheita são manuais.

$\mathrm{AR}=$ Corresponde à atividade arroz de sequeiro que gera uma margem bruta de $\mathrm{R} \$ 542,70 /$ alq, obtida a partir de uma produtividade de 80 sc/alq e um preço médio de $\mathrm{R} \$ 15,99 / \mathrm{sc}$. Também utiliza preparo de solo convencional, trilha mecânica com as demais operações manuais.

HOPA = Corresponde à atividade "quintal doméstico", que inclui hortaliças, frutas e pequenos animais. A margem bruta de $R \$ 4.659,28$ /alq foi calculada com base na produção para suprimento das necessidades familiares com respeito a esses itens. Praticamente todas as operações são feitas manualmente.

$E M=$ Corresponde à atividade erva mate que gera uma margem bruta de $\mathrm{R} \$ 424,00 /$ alq . Trata-se de erval nativo (sob mata), com uma média de produção de 400 arrobas por alqueire a cada 2 anos e preço esperado de $\mathrm{R} \$ 2,12$ /arroba.

FAX = Atividade de produção de pastagem natural sob mata - Faxinal, em terreno sem aptidão para uso agrícola. Esta atividade está vinculada aos rebanhos de carne e leite, estimando-se uma produção de matéria seca de $3.630 \mathrm{Kg} / \mathrm{alq}$. Aqui não se utilizam insumos químicos.

MATA = Atividade mata, que apresenta margem bruta nula por não apresentar retorno financeiro.

AUT $=$ Retiradas para autoconsumo, no valor de $\mathrm{R} \$ 252,00$ mensais, que correspondem ao consumo familiar de alimentos produzidos na propriedade, baseado nas necessidades descritas por Bialoskorski Neto (1988).

$\mathrm{CRESO}=$ Atividade crédito para soja (SO), a uma taxa de juros de $8,75 \%$ ao ano.

CRESONA = Atividade crédito para soja (SONA), a uma taxa de juros de $8,75 \%$ ao ano. 
CREMA = Pagamento das obrigações de crédito tomado para máquinas, a uma taxa de juros de $11,95 \%$ ao ano.

CREFOS = Pagamento das obrigações de crédito tomado para fósforo, a uma taxa de juros de $8,75 \%$ ao ano.

CONTMDO = Atividade contratação de mão-de-obra externa para trabalhos na propriedade, com os valores esperados da diária que variam entre $R \$ 10,77$ e $R \$ 11,55$, segundo os meses do ano.

$\mathrm{TC}=$ Transferência de capital, a uma taxa de juros de $0,5 \%$ ao mês.

As seguintes restrições, que correspondem aos recursos da propriedade do tipo IV, foram consideradas:

$\mathrm{SOLO}=$ Refere-se à ocupação mensal do solo com as diferentes atividades, restrita à área total sob administração dos produtores, de $160 \mathrm{alq}$.

CAIXA = Fluxo de caixa da propriedade, com periodicidade mensal. As vendas de produtos são realizadas em diversos momentos do ano, para fazer frente às despesas, ficando a soja e o milho armazenados na Cooperativa. Por esta razão não se considerou um capital operacional inicial.

$\mathrm{MDO}=$ Corresponde à mão-de-obra ocupada com as diferentes atividades, considerando como valor máximo a disponibilidade de mão-de-obra familiar de 5,4 UTH e permitindo a contratação de mão-de-obra externa (com periodicidade mensal, medida em Dias Homem - $\mathrm{DH}^{21}$ ).

$\mathrm{MAQ}=$ Corresponde à utilização de máquinas e equipamentos pelas diferentes atividades, restrita à disponibilidade da frota própria, com periodicidade mensal (em Horas Máquina $-\mathrm{HM}^{22}$ ). Permite-se, nos meses de outubro e novembro a realização de dois turnos de trabalho e nos meses de janeiro e março, jornadas de 12 horas.

\footnotetext{
${ }^{21}$ Dias Homem = considerou-se uma disponibilidade de 260 dias ao ano.

${ }^{22}$ Horas Máquina = considerou-se o tempo disponível, excluindo-se dias úmidos, domingos e feriados, conforme metodologia descrita por Mialhe (1974). Nos meses de pico foram considerados 2 turnos de trabalho. Os dados sobre precipitação foram obtidos de séries históricas (1989 a 2001) da Estação da SIMEPAR/PR de Cândido de Abreu, a mais próxima da área de estudos.
} 
RESTAUT $=$ Diz respeito à destinação de parte da produção ao autoconsumo, representada por retiradas do caixa de valores correspondentes a, no mínimo, as necessidades alimentares das famílias, baseado em Bialoskorski Neto (1988);

COBINV = Refere-se à transferência de cobertura de inverno (aveia e azevém) das áreas de soja para as atividades leite e carne (vinculam-se, assim, as atividades soja, leite e carne por ser a cobertura rotação do cultivo da soja e alimento para o gado). As UA presentes num alqueire de pastagem de verão necessitam de 0,8 alq de aveia/azevém no período invernal.

BALMILHO = Corresponde a um balanço do milho, possibilitando sua utilização para os animais ou sua comercialização como grão. No sistema atual, o consumo das 4,29 UA de bovinos de leite (que ocupam 1 alq de pastagem de verão) foi de 28,37 sacas de milho.

BALTRITI = Corresponde a um balanço do triticale, conforme descrito para o milho. $\mathrm{O}$ consumo de triticale pelas 4,29 UA de bovinos de leite (que ocupam 1 alq de pastagem de verão) foi de 14,18 sacas.

SOLOPAST = Condiciona área de pastagem de verão e de faxinal a um limite mínimo ( 20 alq no primeiro caso e 5 alq no segundo), visto que estes terrenos não têm aptidão agrícola. Por outro lado, possibilita a alocação para pastagens de terrenos com aptidão agrícola.

PASVERAO = Vincula as áreas de pastagens de verão (Hemarthria e Faxinal) aos rebanhos de leite e carne.

CRESO $=$ Diz respeito à possibilidade de uso (ou não uso) de crédito para a soja (SO).

CRESONA = Refere-se à possibilidade de uso de crédito para a atividade soja, considerada como SONA.

CREMA = Refere-se ao cumprimento das obrigações para com crédito utilizado para compra de máquinas.

CREFOS $=$ Refere-se ao cumprimento das obrigações para com crédito utilizado para aquisição de fósforo. 
AMATA = Corresponde à área estabelecida por lei como reserva florestal (no mínimo, $20 \%$ da área total da propriedade). Considerou-se uma área de mata mínima de 35 alq, que corresponde ao uso atual.

$\mathrm{AFAX}=$ Condiciona a área de Faxinal a 5 alq, pelas características do terreno que não pode ter uso agrícola.

AREAEM = Condiciona-se a área de erva mate a, no máximo, os atuais 5 alq, dado que sua ampliação, mesmo na área de mata, implicaria em novos investimentos (para adensamento de plantas), que não estão contemplados nos atuais coeficientes técnicos da cultura.

AHORTA $=$ Dadas as restrições atuais de mercado local, mencionadas pelos produtores, para os produtos do "quintal doméstico" (hortaliças, frutas e pequenos animais), limitase sua área a no máximo 0,25 alq, suficientes para suprir as necessidades do autoconsumo familiar.

ROTAÇAO $=$ Diz respeito à necessidade de rotação leguminosas/gramíneas, visando à manutenção de adequadas condições fitossanitárias. Segundo os produtores, o milho deve ocupar uma área equivalente a, no mínimo, $20 \%$ da área destinada à soja.

A Tabela 7 mostra a composição de atividades do sistema atual e de dois modelos deterministas (com e sem contratação de mão-de-obra). 
Tabela 7. Composição de atividades do sistema atual e dos modelos deterministas, para a propriedade tipo IV.

\begin{tabular}{l|r|r|r}
\hline \multirow{1}{*}{ Atividades } & Sistema atual & $\begin{array}{c}\text { Modelo determinista } \\
\text { com contratação de mão- } \\
\text { de-obra } \\
\text { (alq) }\end{array}$ & $\begin{array}{c}\text { Modelo determinista } \\
\text { sem contratação de mão- } \\
\text { de-obra } \\
\text { (alq) }\end{array}$ \\
\hline Soja (SO) & 75,00 & 20,00 & 20,00 \\
Soja (SONA) & 0 & 59,82 & 59,82 \\
Milho venda & 23,50 & 16,01 & 16,01 \\
Milho consumo & 0,50 & 0 & 0 \\
Trigo & 2,00 & 61,71 & 61,71 \\
Triticale venda & 6,45 & 0 & 0 \\
Triticale consumo & 1,55 & 0 & 0 \\
Feijão & 0,25 & 2,02 & 2,02 \\
Arroz & 0,25 & 0 & 0 \\
Leite & 7,05 & 0 & 0 \\
Carne & 17,95 & 25,00 & 25,00 \\
Quintal Doméstico & 0,25 & $0,25 *$ & $0,25^{*}$ \\
Erva mate (sob mata) & 5,00 & $5,00^{*}$ & $5,00^{*}$ \\
Mata & 35,00 & $35,00^{*}$ & $35,00^{*}$ \\
M. Bruta**(R\$) & $123.969,81$ & $175.656,60$ & $175.656,60$ \\
\hline
\end{tabular}

Fonte: Dados da pesquisa

* Nos modelos deterministas, tais áreas são impostas por restriç̃es.

** No fluxo de caixa, contabilizam-se saídas referentes ao autoconsumo familiar.

Observa-se pela análise da Tabela 7 que os problemas de maximização das margens brutas conduzem aos mesmos resultados, quer se considere ou não a possibilidade de contratação de mão-de-obra. Ou seja, para compor a combinação de atividades que será descrita a seguir não é necessária a contratação de mão-de-obra externa à propriedade. Assim, ambas soluções geram uma margem bruta de R\$ 175.656,60. No verão, os resultados dos modelos apontam para a implantação de 79,82 alq de soja (20 alq da atividade SO - soja com pastagem invernal e 59,82 alq da atividade SONA - soja sem pastagem invernal); 16,01 alq de milho (ambas culturas totalmente orientadas ao mercado) e 2,02 alq de feijão. No inverno prevê-se a 
implantação de 61,71 alq de trigo. As soluções ótimas preveêm a destinação de 25 alq à carne, o que corresponderia à ocupação de toda a área de pastagens de verão com esta atividade, pois o leite não participou das combinações ótimas nos problemas de maximização. A erva mate estaria ocupando 5 alq (sob mata); o quintal doméstico (hortaliças, frutas e pequenos animais), 0,25 alq e a mata ocuparia 35 alq, sendo tais superfícies impostas por restrições ${ }^{23}$. Os modelos não apontaram para a utilização de crédito para soja e não incorporaram o triticale e o arroz nas soluções ótimas.

Um ponto que havia interesse em esclarecer era o papel do milho no sistema de produção, já que os depoimentos dos produtores apontavam para a redução da área de milho ao mínimo necessário para cumprir com a rotação de culturas. Assim, nos problemas de maximização das margens brutas, quando não se impôs a restrição referente a rotação, os resultados conduziram à mesma combinação de atividades anteriormente descrita, sendo o milho mantido na mesma extensão de área.

Os resultados apresentados, por outro lado, concordam com depoimentos dos agricultores que evidenciaram seu desinteresse pela cultura do feijão, que vem enfrentando, segundo sua percepção, uma grande queda de preços, pelo menos nos últimos três anos. Na propriedade analisada, o feijão vem sendo estabelecido unicamente para suprir o consumo familiar, sem nenhum aprimoramento tecnológico, o que contrasta fortemente com as culturas da soja e do milho. Da forma como é conduzida atualmente, esta cultura apresenta alta demanda de mão-de-obra, especialmente para as operações de capina e colheita, ambas manuais.

Os modelos de maximização de lucro (no caso, margem bruta), consideram que os produtores são neutros ao risco. As combinações de atividades de máximo lucro

\footnotetext{
${ }^{23}$ Caso estas restrições não fossem impostas, o modelo estaria alocando 100 alq à produção de hortaliças, frutas e pequenos animais, 35 alq de erva mate, 20 alq de pasto de verão e 5 alq de faxinal, sem produzir leite ou carne. Para alcançar esta combinação, o modelo apontava para elevada contratação de mão de obra externa em todos os períodos. Essa combinação é impraticável, considerando os objetivos dos produtores e o mercado local.
} 
normalmente conduzem a um nível maior de especialização. No presente estudo, as extensões de soja e milho efetivamente implementadas pelos produtores aproximam-se às expressas no resultado da PL. Observa-se, entretanto, que os produtores diversificam mais, comparativamente à solução apontada pelo modelo convencional de PL. O resultado do modelo de maximização deu maior ênfase que o produtor à atividade carne e descartou a atividade leite. Sabe-se, entretanto, da importância do leite nas unidades de produção familiares por permitir entradas mensais ao caixa, além de ocupar, juntamente com a pecuária de corte, áreas de menor aptidão para a agricultura. Adicionalmente, os bovinos (tanto de corte quanto de leite) representam uma forma de estoque de capital de boa liquidez para fazer frente a situações imprevistas. Tampouco participaram da solução ótima o triticale e o arroz (atividade voltada para o autoconsumo no sistema atual). Além disso, a área destinada a trigo no modelo de maximização é muito superior àquela do sistema atualmente praticado, e esta é uma cultura considerada de alto risco em termos de produtividade por ser conduzida no inverno. Devido a estas ponderações reforça-se a importância de incorporar o risco na análise.

Além da combinação das atividades, a programação linear permite aprofundar o estudo das restrições, que correspondem à disponibilidade dos principais fatores de produção. Segundo Dossa (1994), o conceito mais importante que se depreende da PL é o de valor dual, ou preço sombra, que indica o custo de oportunidade da utilização de uma unidade adicional dos fatores mais restritivos. $\mathrm{O}$ valor dual é interpretado como o custo marginal, existindo, portanto, uma significação econômica ligada ao dual. Se numa solução ótima o fator restritivo não é saturado, o custo marginal da variável dual correspondente será zero. A análise do valor dual mostra os pesos relativos de cada restrição; logo, os pontos de estrangulamento mais importantes dentro de cada sistema de produção. Assim, se o fator não é completamente utilizado, o resultado não o valoriza. Quanto maior for o valor dual, mais restritivo será o fator em análise. Dessa forma, uma restrição é considerada atuante quando o fator de produção que ela representa está sendo utilizado em sua integralidade, sem folga. Essas são as restrições que apresentam preços-sombra não nulos. 
Por outro lado, a análise de sensibilidade do RHS (Right Hand Side), ou seja, dos valores disponíveis de recursos apresentados nas restrições, mostra que "para cada alteração unitária no valor do RHS da restrição em questão, o valor da função objetivo é alterado no valor previsto para o preço-sombra (Dual Value)" e isso acontecerá enquanto o RHS variar dentro de um limite apresentado pelo modelo (Caixeta Filho, 1998).

A Tabela 8 mostra o estado de restrições do modelo determinista sem contratação de mão-de-obra, considerando os principais recursos disponíveis.

Tabela 8. Restrições atuantes, preço-sombra e intervalos de RHS para manutenção do status para a propriedade tipo IV, sem contratação de mão-de-obra.

\begin{tabular}{lc|c}
\hline \multicolumn{1}{c|}{ Restrições Atuantes } & Preço-Sombra (R\$) & Intervalo RHS \\
\hline Solo em outubro (alq) & 857,73 & $98,29-162,02$ \\
Mão-de-obra em novembro (DH) & 8,73 & $76,56-154,89$ \\
Máquina em novembro (HM) & 180,06 & $534,74-603,02$ \\
Área destinada a quintal (alq) & $3.960,67$ & $0,05-1,80$ \\
Área destinada a mata (alq) & $-857,73$ & $5,00-36,89$ \\
Área destinada a erva mate (alq) & 537,38 & $4,81-5,47$ \\
\hline
\end{tabular}

Fonte: Dados da pesquisa

A análise da Tabela 8 mostra que no mês de outubro, dentro do intervalo de área de 98,29 a 162,02 alq, cada alqueire a mais disponibilizado para a produção promove um

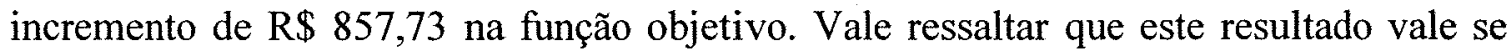
todas as demais restrições forem mantidas constantes, ou seja, a análise vale para as restrições uma a uma, nada se podendo prever se um conjunto delas for alterado simultaneamente. Também nada se pode afirmar caso se esteja fora do intervalo de área mencionado.

Do mesmo modo, os incrementos de uma diária e de uma hora máquina no mês de novembro promoveriam, respectivamente, os acréscimos de $R \$ 8,73$ e $R \$ 180,06$ na 
função objetivo (ceteris paribus). Ao se incrementar em 1 alq, respectivamente, as áreas de quintal, mata e erva mate, promover-se-iam alterações da ordem de R\$3.960,67; -R\$ 857,73 e R\$ 537,38 na margem bruta da propriedade. No caso da mata, por não apresentar nenhum retorno monetário, estaria, segundo o modelo, dando prejuízo, ao ocupar terreno e não permitir a implantação de outra atividade produtiva.

Finalmente, as informações geradas pelos relatórios de análise de sensibilidade dos coeficientes da função objetivo são interessantes por permitirem uma avaliação a respeito do seu nível de incerteza (Caixeta Filho, 1998). Enquanto o valor do coeficiente estiver contido nos intervalos apontados pelo programa, a solução ótima, por exemplo, em termos de áreas a serem cultivadas com cada cultura, continuará sendo a mesma. Esta é uma análise de interesse, já que os produtores não basearam suas respostas em registros formais.

No presente estudo, os resultados se mantêm válidos dentro dos intervalos de variação de alguns coeficientes da função objetivo mostrados na Tabela 9.

Tabela 9. Análise de sensibilidade de alguns coeficientes da função objetivo da propriedade tipo IV.

\begin{tabular}{|c|c|c|c|}
\hline Atividade & Valor atual & Valor mínimo & Valor máximo \\
\hline M. Bruta Soja -SO (R \$/alq) & $1.121,59$ & 863,54 & $2.028,96$ \\
\hline M.B. Soja -SONA (R $\$ / a l q)$ & $1.170,49$ & 263,12 & $1.429,38$ \\
\hline M. B. Trigo-TG (R\$/alq) & 812,36 & 337,45 & 986,93 \\
\hline Preço Triticale (R\$/sc) & 7,59 & $-\infty$ & 15,40 \\
\hline Preço Venda Milho $(\mathrm{R} \$ / \mathrm{sc})$ & 8,64 & 7,82 & 62,92 \\
\hline M. Bruta Leite (R\$/alq) & $1.035,65$ & $-\infty$ & $1.389,12$ \\
\hline M. Bruta Carne (R\$/alq)) & 900,12 & 693,68 & $1.750,60$ \\
\hline M.Bruta Erva mate (R\$/alq) & 424,00 & $-113,38$ & $\infty$ \\
\hline M. Bruta Feijão (R\$/alq) & $1.021,85$ & 847,28 & $14.073,31$ \\
\hline M. Bruta Arroz (R\$/alq) & 542,70 & $-\infty$ & $1.207,15$ \\
\hline M. Bruta Quintal (R\$/alq) & $4.659,28$ & 698,61 & $\infty$ \\
\hline
\end{tabular}

Fonte: Dados da pesquisa 
Da análise da Tabela 9 pode-se perceber que os limites de variação dos coeficientes da função objetivo (para que seja mantida a mesma solução ótima) são relativamente estreitos para as atividades trigo, soja, feijão e pecuária de corte (as diferenças entre os valores atuais e os valores mínimos ou máximos são inferiores a $25 \%$ ), o que equivale dizer que não seriam necessárias grandes variações nas produtividades e/ou preços para modificar a solução ora apresentada. Também se deve chamar a atenção para o preço do milho, cujo valor mínimo apresentado pelo modelo está apenas $9,5 \%$ abaixo do valor esperado.

Para as demais atividades os intervalos de variação dos coeficientes da função objetivo são mais amplos, o que significa que a solução apresentada pelo programa deve se manter para tais atividades, considerando uma margem razoável de variação em produtividades e preços.

\subsubsection{O modelo com incorporação do risco (MOTAD) para a propriedade tipo IV}

Foi incorporado o risco na análise das duas situações anteriormente planteadas para o tipo IV: com e sem a contratação de mão-de-obra externa. Para a construção da fronteira eficiente foram formulados, para cada uma dessas situações, onze problemas de minimização dos desvios absolutos totais, parametrizando-se os valores das margens brutas esperadas. Nas Tabelas 10 e 11 apresentam-se os valores referentes aos onze níveis de margens brutas e desvios, assim como a combinação das principais atividades correspondente a cada um desses níveis, respectivamente para o caso em que ocorre contratação de mão-de-obra externa e para o que se utiliza somente do trabalho familiar. Com os valores de margens brutas e desvios parametrizados podem ser traçadas as fronteiras eficientes para ambas situações. $O$ deslocamento no sentido de diminuição dos desvios pressupõe aumento da aversão ao risco do tomador de decisão. As tabelas apontam, portanto, a estratégia produtiva condizente com cada nível de margem bruta/risco que os produtores estariam dispostos a assumir. 


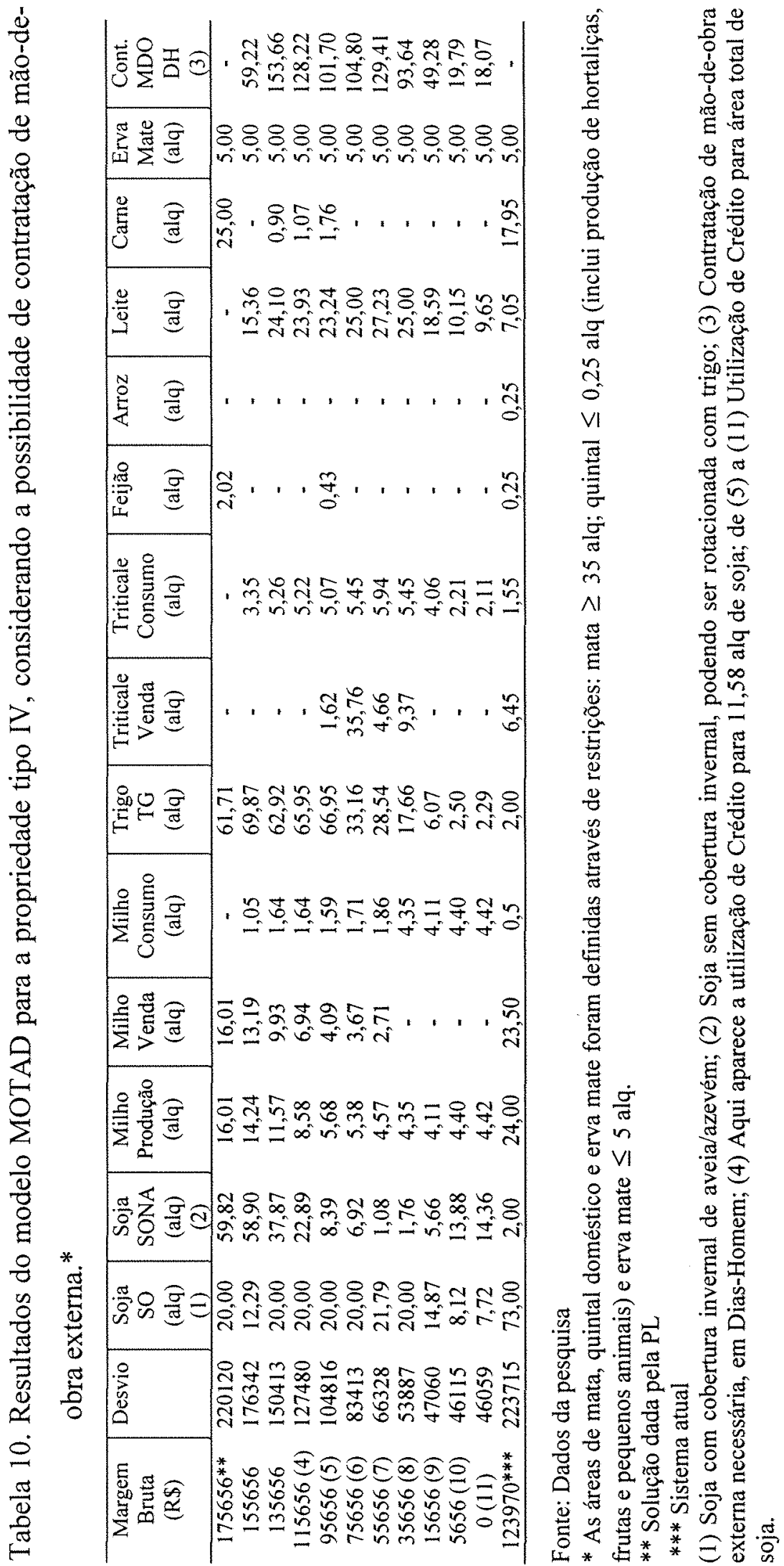




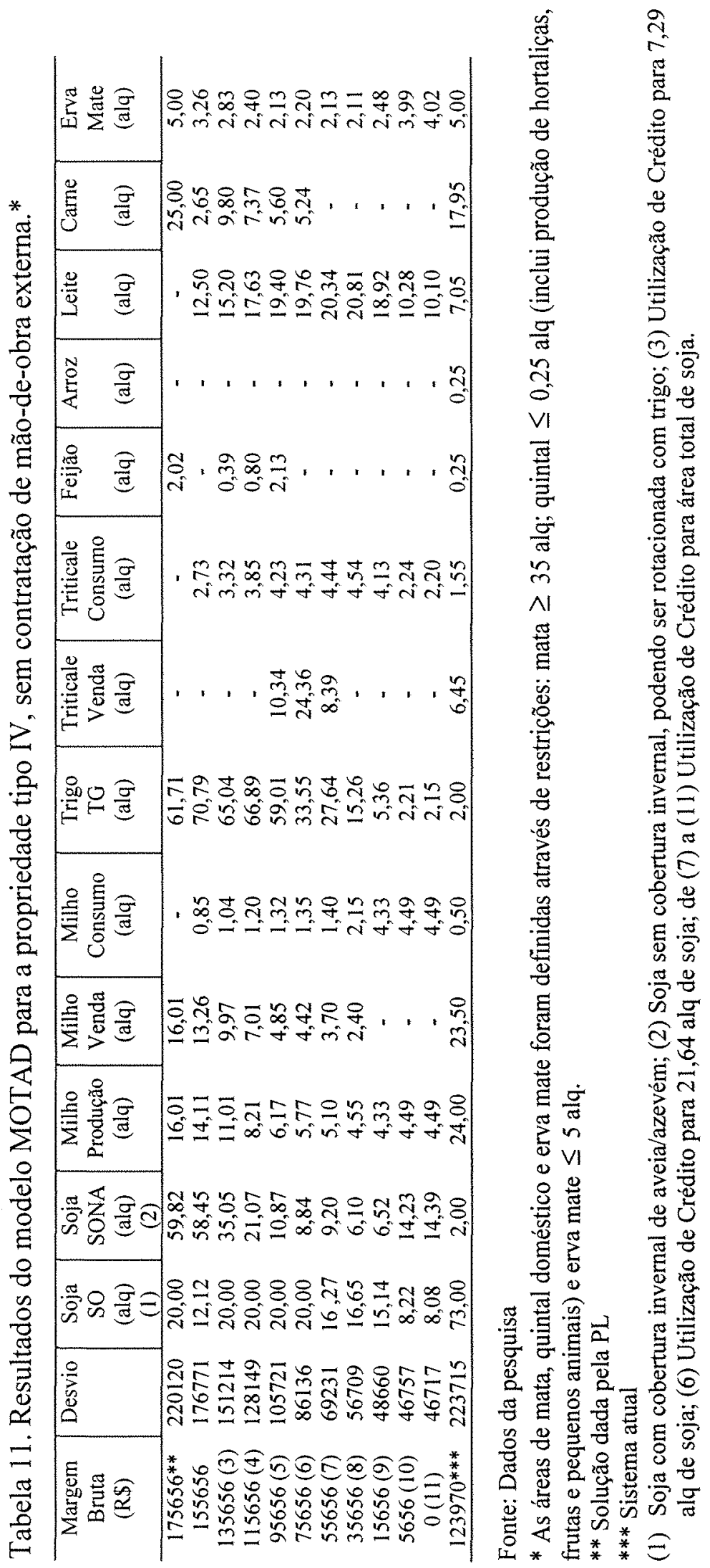


No que diz respeito à simulação das combinações de atividades praticadas pelos produtores, a introdução do risco melhorou os resultados obtidos comparativamente aos do problema de maximização, conforme se pode observar nas Tabelas 10 e 11 . Em ambas situações modeladas (com e sem contratação de mão-de-obra), observa-se que para os níveis mais altos de margem bruta e risco, soja e trigo constituem-se nas atividades mais importantes em termos de área ocupada. Nesses níveis, o modelo apontou para uma produção voltada predominantemente a grãos, em especial a rotação soja/trigo. O milho deve ocupar uma área mínima equivalente a $20 \%$ da área da soja, devido à restrição de rotação imposta, em todos os níveis de margem bruta/risco. Entretanto, nos níveis mais altos de risco, o modelo aloca espontaneamente tais áreas para o milho, independente dessa restrição. No nível mais alto de margem bruta/risco o milho é destinado inteiramente à comercialização na forma de grão. A pequena importância dada ao milho em termos de área, comparativamente à soja, coincide com a opinião dos produtores de que, nos últimos anos, esta cultura só estaria entrando na composição de atividades para cumprir com a necessidade de rotação de culturas. Destaca-se, ainda, a presença da pecuária de corte no nível mais alto de margem bruta/risco, que ocupa toda a área que é atualmente destinada a pastagem de verão (25 alq), quer se contrate ou não mão-de-obra. Esta atividade aparece nos níveis intermediários de margem bruta/risco, ocupando áreas inferiores a 2 alq quando se contrata mão-de-obra e áreas que variam em torno de 3 a 10 alq, quando a mão-de-obra é estritamente familiar, desaparecendo nos maiores níveis de aversão ao risco, em ambos casos.

Nos níveis intermediários de margem bruta/risco a produção de leite ganha destaque. Aumenta, em consequiência, a área da atividade soja/pastagem invernal e diminui a importância das áreas de milho destinadas ao mercado. A produção de triticale para venda na forma de grão aparece somente nesses níveis de margem bruta/risco. Quando não ocorre contratação de mão-de-obra, a área destinada a erva mate é reduzida. 
À medida que aumenta a aversão ao risco, diminuem as áreas destinadas a todas as atividades, com exceção daquelas impostas na modelagem. Neste aspecto destaca-se a cultura do trigo, cuja área se reduz em mais de 25 vezes quando se passa do menor para o maior nível de aversão ao risco. Nesta mesma situação, a área destinada à soja reduzse em menos de 4 vezes. Desaparecem, nos níveis mais baixos de margem bruta/risco, a cultura do feijão assim como as destinações de milho e triticale para venda. Também se observa, quando se diminuem margens e riscos, que ocorre a necessidade de uso de financiamento para a cultura da soja. Esta necessidade surge a partir dos patamares de margens brutas de $\mathrm{R} \$ 115.000,00$ e $\mathrm{R} \$ 135.000,00$, respectivamente nas situações com e sem contratação de mão-de-obra. Ademais, a produção leiteira vai utilizar áreas importantes nos níveis mais baixos de risco. Esta atividade, além do menor nível de risco apresenta a vantagem de permitir entradas mensais ao caixa, o que a torna atrativa nas unidades de produção familiares. A ausência da pecuária de corte nas soluções ótimas para agricultores aversos ao risco pode dever-se, segundo Peres (1981), à não incorporação da "dimensão" liquidez no enfoque de risco. Para a autora, ativos fixos ou semifixos (característica do capital empregado em bovinos) podem ser fundamentais como hedging contra eventos extremos dos quais o agricultor desconhece a função densidade.

Observa-se que o feijão surge em pequenas extensões apenas nos níveis altos e intermediários de risco, desaparecendo à medida que aumenta a aversão ao risco dos produtores. Já a cultura do arroz não aparece em nenhum nível de margem bruta/risco, para ambas situações analisadas. No sistema atual do produtor, ambas atividades têm unicamente a finalidade de autoconsumo. O milho, nos níveis baixos de retorno/risco, é destinado exclusivamente para o rebanho leiteiro. $\mathrm{O}$ modelo, nos níveis mais baixos de margem bruta/risco, vê-se forçado a produzir milho para cumprir com a restrição de rotação de culturas e ao mesmo tempo vê-se restrito ao nível de margem bruta parametrizado. Nesta situação, embora a produção seja superior à necessidade do rebanho, ela não é alocada para venda, ocorrendo "desperdício" do produto. Este é um artifício matemático usado pelo modelo para forçar a redução da renda nos níveis mais 
baixos de risco. Caso a restrição de rotação não fosse colocada nos níveis mais baixos de margem bruta/risco, os resultados apontariam para um aumento da área de soja e eliminação do milho e da bovinocultura de leite. Pelo exposto, considerando o nível tecnológico, a dotação de recursos e as restrições da grande propriedade, as culturas do milho, feijão e arroz não apresentam vantagens comparativas, especialmente em relação à cultura da soja.

Apesar da redução das áreas cultivadas à medida que aumenta a aversão ao risco, alguma produção deve ser mantida, mesmo ao assumir níveis muito baixos de risco, para garantir recursos para a subsistência familiar e cumprimento das obrigações creditícias. Por tal razão observamos a implementação de atividades produtivas mesmo com um valor nulo de margem bruta do estabelecimento (obtida descontando-se os pagamentos relativos ao financiamento utilizado e ao autoconsumo).

A análise das Tabelas 10 e 11 permite, ainda, visualizar que as diferenças mais significativas entre os cenários com e sem contratação de mão-de-obra encontram-se nas extensões de área destinadas às atividades pecuária leiteira, pecuária de corte e erva mate, especialmente nos níveis intermediários de risco. A combinação de atividades do sistema atual aproxima-se do nível máximo de risco/margem bruta para as áreas destinadas à soja, milho e pecuária de corte, principais geradoras de renda. Observa-se, entretanto, que os produtores diversificam mais que o observado nesse nível, incluindo áreas significativas de produção de leite e triticale, além de praticamente suprirem as necessidades do autoconsumo familiar. A área destinada a trigo na propriedade aproxima-se daquelas apontadas pelo modelo nos níveis mais altos de aversão ao risco. Vale ressaltar que são insignificantes as diferenças observadas nos níveis de margens brutas e riscos alcançados nas situações com e sem contratação de mão de obra, o que explicaria a decisão dos produtores de empregar quase que exclusivamente a força de trabalho familiar na propriedade. 
Em seu sistema atual de produção, os produtores parecem empregar na prática uma estratégia que por um lado os aproxima ao conceito de empresários que visam maximização dos retornos, mas que por outro ainda os mantêm ligados à agricultura tradicional, via atividades de menor risco e que representem entradas periódicas ao caixa (como o leite), manutenção de uma espécie de "poupança" na forma de rebanho de carne e produção de bens para suprir as necessidades alimentares das famílias. Tais características comportamentais que ligam estes produtores à agricultura tradicional são difíceis de serem captadas no modelo. Uma forma de contornar o problema proposta por Singh, citado por Peres (1976), é a imposição de restrições referentes ao autoconsumo, através de áreas mínimas para as culturas de subsistência. Peres sugere, ainda, que ao tratar os produtos destinados à subsistência como as demais culturas destinadas à comercialização, eles podem não entrar na solução por ter seu risco superestimado, dado que o componente preço da receita esperada é irrelevante no caso do autoconsumo, sendo a única fonte de risco a variação na produtividade.

Conforme discutido anteriormente, é plausível abandonar a pressuposição que os agricultores maximizam lucro quando se introduz o conceito da empresa familiar como unidade tomadora de decisão. Neste caso, a propriedade é, ao mesmo tempo, uma unidade de produção e de consumo, e a família se constitui numa unidade de decisão frente a um complexo conjunto de decisões concernentes a oportunidades de produção e investimento. No caso de empresas familiares tomadoras de decisão, a utilidade deveria ser maximizada, e, retorno e risco seriam componentes da função utilidade do produtor. Em função de tal complexidade, é difícil reproduzir completamente através do modelo o processo de tomada de decisão dos produtores (Peres, 1976). 


\subsubsection{Localização do sistema atual na fronteira eficiente e coeficiente de aversão ao risco da propriedade tipo IV}

A localização do sistema atual em relação à fronteira eficiente se fez em função da margem bruta da propriedade e da soma de seus desvios negativos em relação às receitas esperadas. Conforme se pode visualizar nas Figuras 3 e 4, o sistema atual se localiza abaixo da curva de fronteira eficiente, o que pode significar que não estaria alcançando eficiência máxima na produção, no que diz respeito à relação entre risco e receita esperada. Em outras palavras, o seu mix de atividades pode não conduzir à maior eficiência possível. O ponto da fronteira que apresenta a menor distância até o ponto representativo do sistema atual encontra-se entre os dois níveis mais altos de margem bruta/risco, conforme indicado pela linha tracejada nas figuras.

Conforme já foi mencionado, o coeficiente de aversão ao risco dos produtores corresponde à inclinação da curva da fronteira eficiente no ponto que minimiza a distância ao sistema atual. No caso do sistema de produção do tipo IV, na situação em que ocorre a contratação de mão-de-obra externa o coeficiente de aversão ao risco é 0,4569 e quando se utiliza exclusivamente o trabalho familiar, 0,4614 .

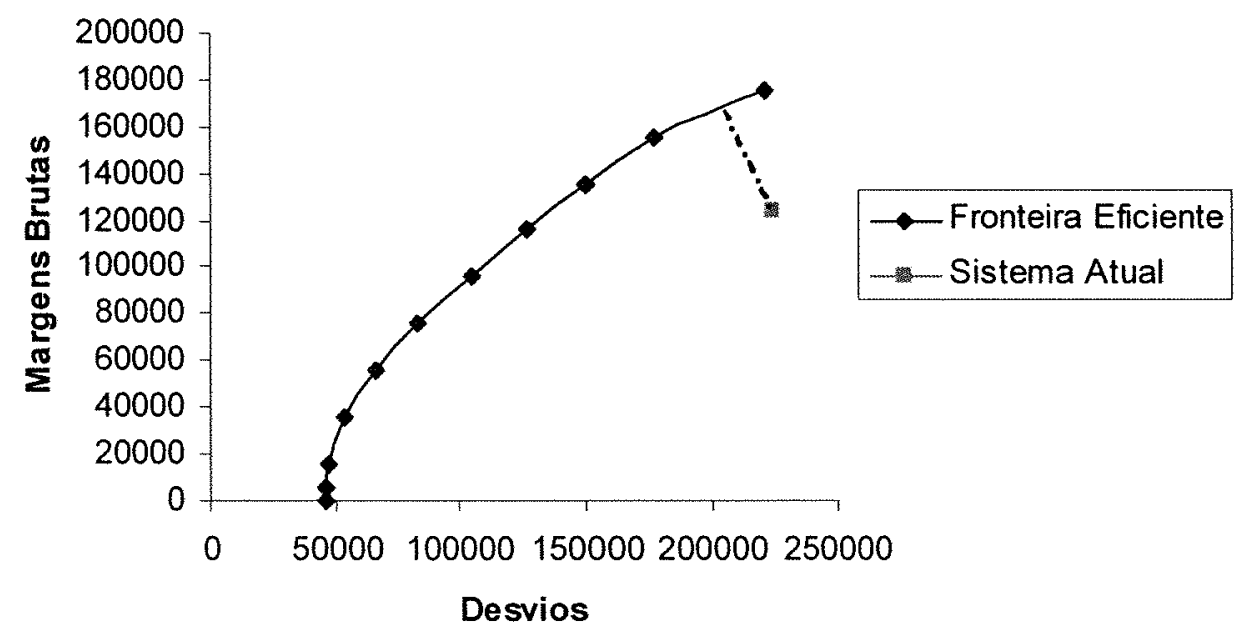

Figura 3 - Fronteira eficiente da propriedade tipo IV, com contratação de mão-de-obra. 


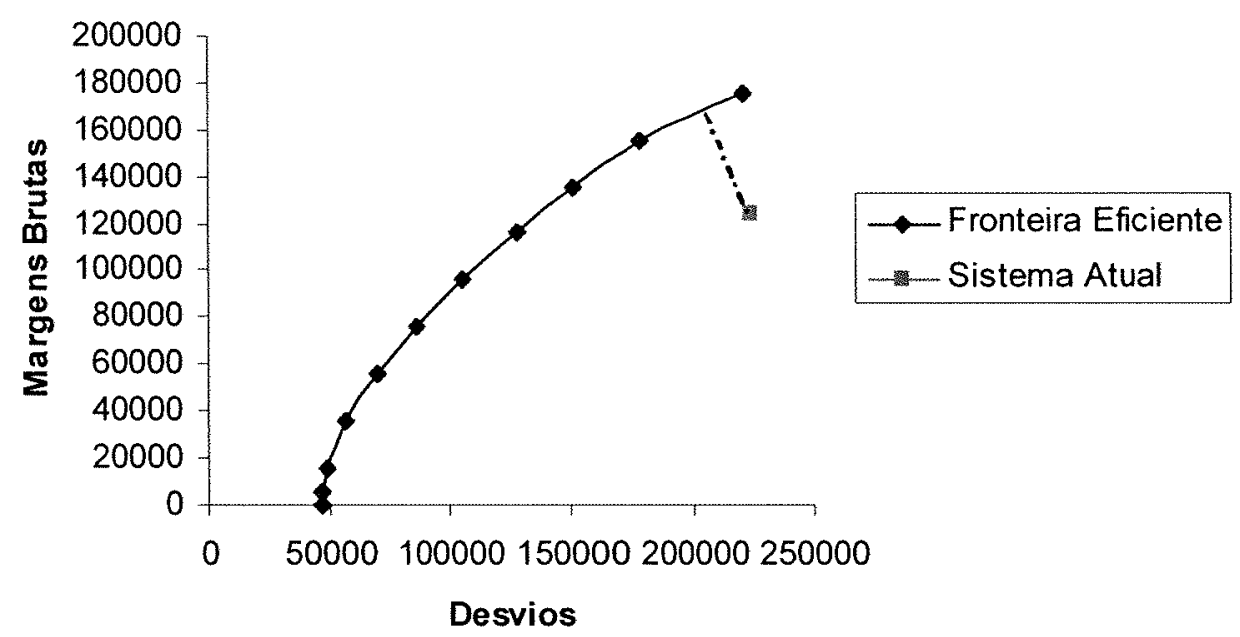

Figura 4 - Fronteira eficiente da propriedade tipo IV, sem contratação de mão-de-obra.

\subsubsection{Diversificação de atividades como forma de redução do risco para a propriedade tipo IV}

As correlações entre os desvios em relação à tendência, calculados para as diferentes atividades, podem traduzir a importância da diversificação no tratamento do risco. Em especial, a existência de valores negativos e altos demonstra a vantagem da diversificação como forma de redução do risco. A tabela 12 mostra a matriz de correlação entre as atividades produtivas que fazem parte da função de produção do agricultor do tipo IV.

Observam-se correlações negativas ou próximas de zero entre a renda do trigo e as rendas do milho, do leite, da carne, da erva mate e do feijão. A renda do triticale apresenta correlações próximas a zero com as rendas do leite e do feijão. 


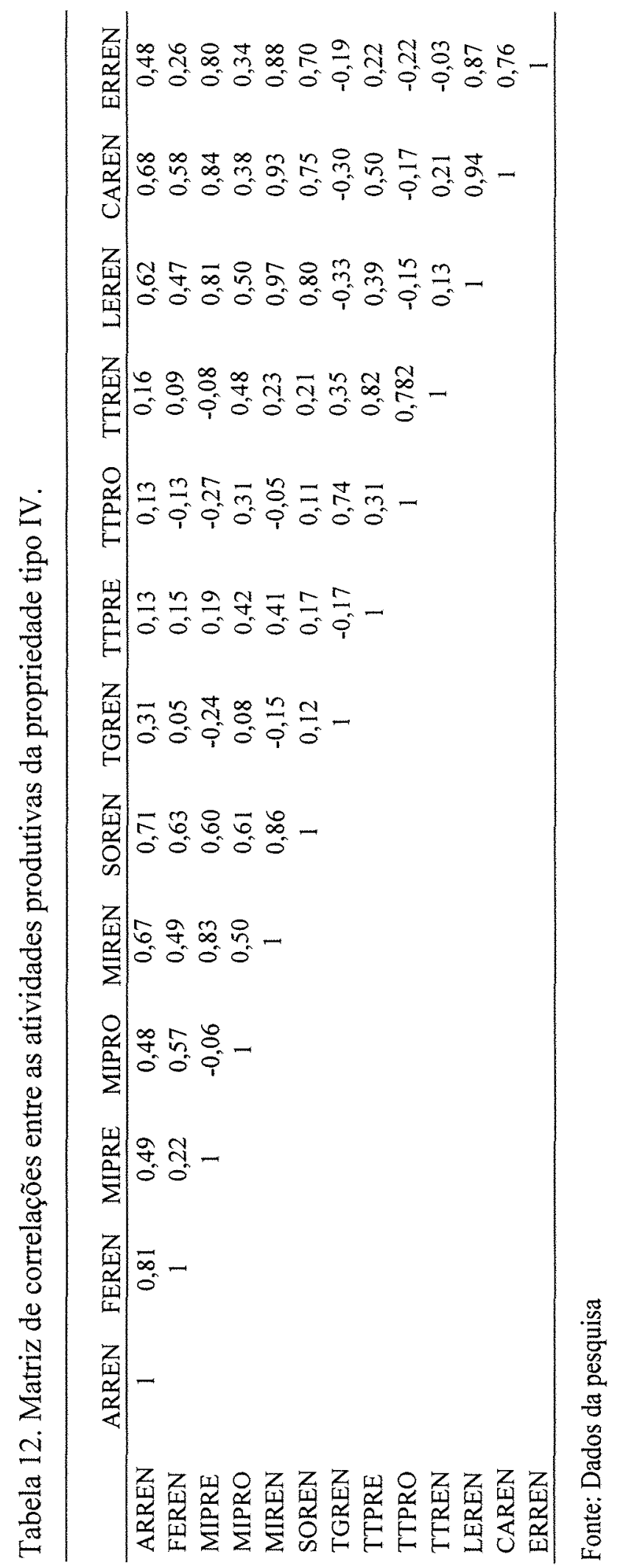


Os valores negativos da matriz de correlação explicam que os produtores utilizam a diversificação, em parte, com o objetivo de minimizar os riscos. Aparentemente, entretanto, a diversificação não estaria se dando somente com esse objetivo, mas possivelmente também pela natureza familiar do estabelecimento, onde tradicionalmente se pratica a diversificação, especialmente através da inclusão de ítens para consumo das famílias.

\subsection{Sistema de produção da propriedade tipo I}

\subsubsection{Características da exploração}

O produtor é originário de uma família de pequenos produtores do Rio Grande do Sul que migrou para o Paraná no início dos anos 80. A propriedade é de apenas três alqueires. Um alqueire adicional é tomado em arrendamento para completar sua área de cultivo. O produtor é ainda jovem, com 34 anos, e cursou somente a terceira série do ensino básico. A família é composta por quatro pessoas, havendo se contabilizado 2 UTH como a força de trabalho familiar. Este produtor não recebe nenhum tipo de assistência técnica. Trata-se de uma exploração descapitalizada (o capital ligado à produção é de $R \$ 2.080,00$ ), contando apenas com equipamentos e ferramentas manuais para a realização das operações agrícolas.

Pela dotação de recursos, pode ser considerada uma propriedade representativa do tipo I, descrito no item 4.3.2. Entretanto, as características comportamentais do produtor o diferenciam do grupo. No tipo I, apenas um entre doze estabelecimentos cultiva a soja. Para o grupo, a produção de autoconsumo tem maior peso no Valor Agregado Total dos estabelecimentos, seguida do milho, feijão e leite para comercialização. No caso deste produtor, a estratégia adotada contempla a contratação de serviços de máquinas para produzir a soja. Esta representa o principal produto na formação da margem bruta da propriedade e é totalmente destinada ao mercado. As 
demais culturas são produzidas de forma predominantemente manual, visando o consumo da família. Nem todos os produtos necessários ao autoconsumo advêm da propriedade, como é o caso do arroz e leite. O produtor vem utilizando esta estratégia para liberar suas horas de serviço, que procura empregar como mão-de-obra volante. Pode-se considerar que este sistema de produção ainda não está estabilizado em termos de sua combinação de atividades: o agricultor vem experimentando alternativas para compor o seu mix de atividades, buscando o melhor uso de seus escassos recursos. $\mathrm{O}$ produtor vem buscando desenvolver uma agricultura em tempo parcial. Conforme se disse anteriormente, a escolha deste sistema de produção para análise decorre de uma tendência de ampliação desta estratégia (segundo depoimentos dos agricultores e técnicos locais) entre agricultores jovens e filhos de pequenos produtores, que arrendam áreas pequenas para obter renda adicional. Os técnicos locais e a CRESOL-Pitanga gostariam de contar com maior embasamento para se posicionar frente a tal tendência.

Este produtor aspira permanecer na propriedade. Gostaria de poder adquirir mais terra, fato que considera impossível pela baixa renda que obtém através de suas atividades produtivas. A produção de hortaliças e peixes, atividades pelas quais demonstrou interesse, seriam impraticáveis, dadas a falta de mercado local, a distância e as péssimas condições de acesso à propriedade. Assim como o grande produtor, manifesta a preocupação de que seus filhos prossigam nos estudos.

As atividades implementadas na propriedade do tipo I são a soja, milho, feijão, erva mate, além do quintal doméstico, onde está incluída a produção de hortaliças, frutas e aves. Assim como a soja, a erva mate tem fins comerciais. O milho é anualmente plantado em pequenas áreas, visando o autoconsumo. 


\subsubsection{Modelo determinista para a propriedade tipo I: atividades, restrições, função objetivo e análises de sensibilidade}

$\mathrm{Na}$ função objetivo estão incluídas as receitas advindas de cada atividade produtiva, venda de mão-de-obra e transferências de capital a uma taxa de juros de $0,5 \%$ ao mês (elementos com sinais positivos) e as despesas, referentes a gastos com autoconsumo e pagamento de crédito (elementos com sinais negativos).

As atividades consideradas na definição do modelo de Programação Linear convencional da propriedade representativa do tipo I foram:

$\mathrm{SO}=$ Atividade soja, inteiramente destinada ao mercado. Com rendimento de $100 \mathrm{sc} 60$ $\mathrm{Kg} / \mathrm{alq}$, gera, a um preço esperado de $\mathrm{R} \$ 17,67 / \mathrm{sc}$, uma margem bruta de $\mathrm{R} \$ 692,11 / \mathrm{alq}$. A esta atividade está associada a cobertura invernal de azevém perene, com fins de rotação cultural. Utiliza o sistema de plantio direto, controle químico mecanizado de invasoras e colheita mecânica, tudo com pagamento do serviço de máquinas.

MI = Atividade milho. Produzido de forma manual, com exceção do preparo do solo. Tem um rendimento de 160 sc/alq e gera uma margem bruta de $R \$ 716,28 /$ alq (a um preço esperado de $\mathrm{R} \$ 8,64)$.

$\mathrm{FE}=$ Corresponde à atividade feijão, da qual se obtém uma margem bruta de $\mathrm{R} \$ 2.932,58 / \mathrm{alq}$, com um rendimento de 80 sc/alq e um preço esperado de $\mathrm{R} \$ 42,69 / \mathrm{sc}$. A cultura é conduzida em pequena área, de forma manual, quase como se tratasse de uma produção hortícola, já que se destina ao autoconsumo.

HOPA = Corresponde à atividade "quintal doméstico", que inclui hortaliças, frutas e aves. A margem bruta de $\mathrm{R} \$ 4.659,36 /$ alq foi calculada com base na produção para suprimento das necessidades familiares. As operações culturais são todas realizadas de forma manual.

$E M=$ Corresponde à atividade erva mate que gera uma margem bruta de $R \$ 424,00 /$ alq. Trata-se de erval nativo (sob mata), com uma média de produção de 400 arrobas por alqueire a cada 2 anos e preço esperado de $\mathrm{R} \$ 2,12 /$ arroba. 
MATA = Atividade mata, que apresenta margem bruta nula por não apresentar retorno financeiro.

AUT $=$ Retiradas para autoconsumo, no valor de $\mathrm{R} \$ 126,00$ mensais, que correspondem ao consumo familiar de alimentos produzidos na propriedade, baseado nas necessidades descritas por Bialoskorski Neto (1988).

CRESO $=$ Atividade crédito para soja, a uma taxa de juros de $4 \%$ ao ano (especial para pequenos produtores).

VENDAMDO = Atividade venda de mão-de-obra como volante, com valores esperados da diária que variam entre $\mathrm{R} \$ 10,77$ e $\mathrm{R} \$ 11,55$, segundo os meses do ano.

As restrições consideradas foram:

SOLO $=$ Refere-se à ocupação mensal do solo com as diferentes atividades, restrita à área total sob administração do produtor, de 4 alq.

CAIXA = Fluxo de caixa da propriedade, com periodicidade mensal e considerando vendas periódicas de produtos.

$\mathrm{MDO}=$ Corresponde à mão-de-obra ocupada com as diferentes atividades, considerando como limite a disponibilidade de mão-de-obra familiar de 2,0 UTH, que corresponde a uma disponibilidade de 43,33 DH/mês.

RESTAUT $=$ Diz respeito à destinação de parte da produção ao autoconsumo, representada por retiradas do caixa de valores correspondentes a, no mínimo, as necessidades alimentares da família, baseado em Bialoskorski Neto (1988);

$\mathrm{CRESO}=$ Diz respeito à possibilidade de uso (ou não uso) de crédito para a soja. AMATA = Corresponde à área legal para reserva florestal (no mínimo, 20\% da área total da propriedade). Considerou-se uma área de mata mínima de 0,5 alq, que corresponde ao uso atual.

$\mathrm{AREAEM}=$ Condiciona-se a área de erva mate a, no máximo, os atuais $0,25 \mathrm{alq}$, uma vez que sua ampliação implicaria em novos investimentos, que não estão previstos nos atuais coeficientes técnicos da cultura. 
AHORTA $=$ Dadas as restrições atuais de mercado local para os produtos do quintal doméstico, limita-se sua área ao máximo de 0,125 alq, suficientes para suprir as necessidades do autoconsumo familiar.

ROTAÇAO $=$ Diz respeito à necessidade de rotação leguminosas/gramíneas, visando à manutenção de adequadas condições fitossanitárias. Previu-se, como para o tipo IV, que o milho deva ocupar uma área equivalente a, no mínimo, $20 \%$ da área destinada à soja.

Antes de partir para a descrição dos resultados, deve-se ressaltar que uma limitação deste estudo é a ausência de estimativas para mensurar a oferta e demanda de trabalho na região para alimentar o modelo. Deste modo, lança-se mão de possibilidades hipotéticas que servem para orientar a discussão acerca dos resultados.

Assim, ao se deixar aberta a possibilidade de venda de mão-de-obra, prevê-se a venda de 485,99 diárias (do total disponível de 520), o plantio de 2,81 alq de soja, 0,56 alq de milho e a destinação de 0,125 alq ao quintal doméstico e 0,5 alq de mata. $O$ feijão não participa da solução ótima. O resultado aponta para o uso de crédito para toda a lavoura de soja, e, dessa combinação de atividades gerar-se ia uma margem bruta anual de R \$ 7.028,78. Ressalta-se que quando a restrição de rotação soja/milho não é imposta, prevê-se a venda de 506,96 diárias no ano e o plantio de 3,375 alq de soja, não participando da solução ótima o feijão e o milho. Aqui, o resultado do modelo também aponta para o uso de crédito para toda a lavoura de soja, e, a partir dessa combinação de atividades a margem bruta anual seria de $R \$ 7.271,93$. Entretanto, a não imposição de nenhuma restrição à venda de mão-de-obra implica na venda de, praticamente, toda a força de trabalho da exploração, incluídas a mão-de-obra da esposa e do filho de 13 anos, que se dedicam a meio período aos trabalhos da propriedade. Os resultados mostram, portanto, que é mais interessante empregar a mão-de-obra fora da propriedade a produzir milho e feijão, considerando o atual padrão tecnológico do produtor.

Considerando-se a possibilidade de que apenas o produtor empregue externamente sua mão-de-obra - o equivalente a $21,67 \mathrm{DH}$ por mês - a solução ótima 
aponta uma margem bruta anual de $\mathrm{R} \$ 4.630,37$. Neste caso, a combinação ótima de atividades abarca: 2,63 alq de soja; 0,65 alq de milho e 0,09 alq de feijão. O quintal doméstico aparece com o montante máximo estabelecido na restrição $(0,125$ alq) e a erva mate não participa da solução ótima. $O$ modelo prevê a utilização de crédito para toda a lavoura de soja. Cabe salientar, que mesmo que não se imponha a restrição de rotação soja/milho a solução permanece a mesma, em termos de combinação de atividades.

Quando não se admitiu a possibilidade de venda de mão-de-obra, prevendo limitações na oferta de trabalho no mercado local, o modelo apresentou uma solução ótima que alcançou uma margem bruta de apenas $\mathrm{R} \$ 1.841,76$, obtida a partir do seguinte mix de atividades: 1,85 alq de soja; 1,33 alq de milho; 0,18 alq de feijão e 0,015 alq de erva mate. Aqui o quintal doméstico também aparece com área equivalente à máxima admitida pela restrição. O modelo também prevê a utilização de crédito para a soja. Também neste caso, o fato de não se impor a rotação soja/milho conduz à mesma solução ótima.

Deve-se recordar que no cálculo da margem bruta das propriedades, tanto no sistema atual quanto nos modelos, estão previstas saídas do caixa destinadas a cobrir as necessidades alimentares das familias. As margens brutas apresentadas estariam destinadas a suprir, portanto, outras necessidades das famílias (saúde, vestuário, transporte, etc) e investimentos relacionados à produção agropecuária.

Na Tabela 13 podem-se comparar as combinações de atividades do sistema atual e dos modelos deterministas mencionados. 
Tabela 13. Composição de atividades do sistema atual e dos modelos deterministas, para a propriedade tipo I.

\begin{tabular}{|c|c|c|c|c|}
\hline Atividades & $\begin{array}{c}\text { Sistema } \\
\text { atual }\end{array}$ & $\begin{array}{c}\text { Modelo } \\
\text { determinista } \\
\text { com venda } \\
\text { irrestrita de } \\
\text { mdo (I) }\end{array}$ & $\begin{array}{c}\text { Modelo } \\
\text { determinista com } \\
\text { venda de } 21,67 \\
\mathrm{DH} / \mathrm{mês} \\
\text { (II) }\end{array}$ & $\begin{array}{c}\text { Modelo } \\
\text { determinista sem } \\
\text { venda de mdo } \\
\text { (III) }\end{array}$ \\
\hline Soja (alq) & 3,225 & 2,81 & 2,63 & 1,85 \\
\hline Milho (alq) & 0,125 & 0,56 & 0,65 & 1,33 \\
\hline Feijão (alq) & 0,025 & 0 & 0,09 & 0,18 \\
\hline Quintal (alq) & 0,125 & $0,125^{*}$ & $0,125^{*}$ & $0,125^{*}$ \\
\hline Erva mate sob mata (alq) & 0,25 & 0 & 0 & 0,02 \\
\hline Mata (alq) & 0,500 & $0,50^{*}$ & $0,50^{*}$ & $0,50^{*}$ \\
\hline Venda de mão-de-obra (diárias) & 24,000 & 506,96 & 260,00 & 0 \\
\hline Margem $\operatorname{Bruta}^{* *}(\mathrm{R} \$)$ & $1.753,88$ & $7.028,78$ & $4.630,37$ & $1.841,75$ \\
\hline
\end{tabular}

Fonte: Dados da pesquisa

* Nos modelos deterministas, tais áreas são impostas por restrições.

** No fluxo de caixa, contabilizam-se saídas referentes ao autoconsumo familiar.

A análise das três situações modeladas possibilita visualizar que o modelo atribui grande importância à venda de mão-de-obra, comparativamente às atividades milho e feijão. A estratégia de introduzir uma atividade que demande pouca mão-de-obra (soja), para liberá-la para venda parece ser "validada" pelo modelo, frente às atuais opções produtivas e considerando o atual nível tecnológico do produtor. A análise da Tabela 13 mostra, ainda, que em seu sistema atual, o produtor prioriza a produção de soja. Anualmente, a área de milho implantada é suficiente apenas para o consumo na propriedade, não satisfazendo a necessidade inerente à rotação de culturas. O produtor reconhece essa limitação e se preocupa com o fato. $\mathrm{Na}$ entrevista ele coloca que dada a pequena extensão da propriedade, por motivos operacionais, deveria realizar o plantio de milho a cada 6 anos, com a finalidade de rotação, ocupando então a mesma área dedicada à soja. Entretanto, afirma que, na prática, a decisão de plantar ou não milho nesse intervalo de tempo passa pela avaliação do estado fitossanitário da soja no momento, podendo o plantio do milho ser ainda mais postergado. Podem-se atribuir, 
então, razões econômicas (e não falta de conhecimento) ao não cumprimento de requisitos técnicos para a rotação soja/milho.

Se o produtor efetivamente fizesse a rotação soja/milho ao longo dos seis anos, como considera desejável (cinco anos de soja para um ano de milho), ainda assim, os modelos deterministas II e III estariam prevendo uma área menor de soja e uma área maior de milho, ao contabilizar esse período de tempo. Também as áreas de feijão previstas pelo modelo seriam superiores à implantada pelo agricultor.

Entretanto, áreas superiores de milho e feijão, utilizando o atual padrão tecnológico, implicam no dispêndio de grande quantidade de trabalho, já que a maioria das operações é realizada manualmente. $\mathrm{Na}$ opinião do agricultor, tal esforço não seria recompensado em termos de renda adicional. Analisando o caso em que não ocorre emprego externo da mão de obra familiar, a margem obtida é de $\mathrm{R} \$ 1.841,75$ no modelo, contra R $\$ 1.491,32$ no sistema atual (retirado, neste caso, o valor referente ao trabalho externo). Em vista disso, frente às alternativas produtivas que maneja, o produtor prefere optar por aquelas que menos demandem trabalho na propriedade, aguardando oportunidades de trabalho externo. Aparentemente, entretanto, a demanda por mão-deobra volante não é abundante, uma vez que o produtor mencionou haver vendido somente 24 jornadas de trabalho no ano agrícola analisado, durante os meses de outubro, novembro e dezembro.

Evidencia-se, assim, a fragilidade deste tipo de sistema de produção, tanto pela dificuldade técnica de sustentação da produção de soja sem adequado sistema de rotação, quanto pela necessidade de contar sistematicamente com emprego externo à propriedade. Decorrem daqui duas linhas de trabalhos de pesquisa: a determinação mais precisa do mercado de trabalho na região, para orientar possíveis políticas de geração de emprego, e, a busca de alternativas produtivas que ocupem a mão de obra na propriedade, mas que propiciem uma maior geração de renda. Como mencionado 
anteriormente, trata-se de um sistema de produção ainda em construção, ao qual interessa contar com um leque maior de alternativas que as atualmente consideradas.

A Tabela 14 mostra o estado de restrições da propriedade tipo I, considerando os principais recursos produtivos, para o modelo determinista que considera a venda de mão-de-obra (equivalente a $21,67 \mathrm{DH} / \mathrm{mês}$ ).

Tabela 14. Restrições atuantes, preço-sombra e intervalos de RHS para manutenção do status para a propriedade tipo I, com venda de mão-de-obra equivalente a $21,67 \mathrm{DH}$.

\begin{tabular}{lr|c}
\hline \multicolumn{1}{c|}{ Restrições Atuantes } & Preço-Sombra & Intervalo RHS \\
\hline Solo em Janeiro & 695,81 & $1,37-4,00$ \\
Mão-de-obra em janeiro & 9,59 & $22,43-47,51$ \\
Mão-de-obra em maio & 0,05 & $39,97-104,05$ \\
Área destinada a mata & $-695,81$ & $0-3,13$ \\
Área destinada a quintal & 4035,23 & $0-3,49$ \\
Venda mão-de-obra ago. & 11,75 & $0-42,57$ \\
Venda mão-de-obra set. & 11,32 & $0-25,15$ \\
Venda mão-de-obra out. & 11,37 & $0-33,90$ \\
Venda mão-de-obra nov. & 11,26 & $0-40,56$ \\
Venda mão-de-obra dez. & 11,53 & $0-39,95$ \\
Venda mão-de-obra jan. & 2,08 & $17,49-42,57$ \\
Venda mão-de-obra fev. & 11,58 & $0-42,57$ \\
Venda mão-de-obra mar. & 11,57 & $0-42,57$ \\
Venda mão-de-obra abr. & 11,53 & $0-41,65$ \\
Venda mão-de-obra mai. & 11,61 & $0-25,03$ \\
Venda mão-de-obra jun. & 11,57 & $0-42,57$ \\
Venda mão-de-obra jul. & 11,36 & $0-42,57$ \\
\hline
\end{tabular}

Fonte: Dados da pesquisa

A análise da Tabela 14 mostra que, no mês de janeiro e dentro do intervalo de área de 1,37 a 4 alq, cada alqueire disponibilizado para a produção, implica num incremento de $\mathrm{R} \$ 695,81$ na função objetivo (ceteris paribus). Visto de outra forma: a 
redução de 1 alq no intervalo mencionado provoca um decréscimo $R \$ 695,81$ na margem bruta da propriedade. Este dado é importante já que o produtor arrenda um dos quatro alqueires de que dispõe.

O mesmo tipo de análise vale para as demais restrições atuantes. Recorda-se que uma unidade da restrição relacionada ao autoconsumo corresponde a um gasto mensal de $R \$ 126,00$; por se tratar de saída do caixa aparece com valor negativo. Já a área destinada à mata, por não apresentar nenhum retorno monetário (coeficiente zero na função objetivo), provocaria perda monetária, ao ocupar terreno e não permitir a implantação de outra atividade produtiva. Geraria incremento importante à função objetivo a disponibilização de um alqueire da atividade quintal doméstico, dentro do intervalo de RHS mencionado, se não existissem restrições de mercado a tal produção. Finalmente, chama-se a atenção para a restrição "venda de mão-de-obra", cujo valor máximo foi fixado em 21,67 DH mensais. Se esse limite fosse ampliado em 1 jornada, a margem bruta da propriedade se elevaria nos montantes especificados pelo preçosombra, superiores a R \$11,00 exceto no mês de janeiro (sempre dentro dos intervalos apontados de RHS). Entretanto, o aprofundamento dessa análise requer o estudo do mercado de trabalho local, conforme já mencionado.

A análise de sensibilidade dos coeficientes da função objetivo é apresentada na Tabela 15. A tabela mostra que os valores atuais das margens brutas da soja e do milho estão muito próximos de seus limites máximo e mínimo, respectivamente. Pequenas variações nos preços e/ou produtividades destas culturas podem alterar a solução ótima apresentada pelo modelo. Para as demais atividades, especialmente para a venda de mão-de-obra, os limites para que se mantenha a mesma solução ótima são muito mais amplos. 
Tabela 15. Análise de sensibilidade dos coeficientes da função objetivo da propriedade tipo I, com venda de mão-de-obra equivalente a $21,67 \mathrm{DH}$.

\begin{tabular}{lcccc}
\hline \multicolumn{1}{c}{ Atividade } & Valor atual & Valor mínimo & Valor máximo \\
\hline M. Bruta Soja (R\$alq) & 692,11 & 444,21 & 693,82 \\
M.Bruta Milho (R\$alq) & 716,28 & 714,57 & 1087,87 \\
M. Bruta Feijão (R\$/alq) & 2932,58 & 631,72 & 3431,05 \\
M.Bruta Horta (R\$/alq) & 4659,36 & 624,13 & $\infty$ \\
M.Bruta Erva mate (R\$/alq) & 424,00 & $-\infty$ & 671,90 \\
Venda mão-de-obra ago. & 11,12 & $-0,63$ & $\infty$ \\
Venda mão-de-obra set. & 10,77 & $-0,55$ & $\infty$ \\
Venda mão-de-obra out. & 10,87 & $-0,50$ & $\infty$ \\
Venda mão-de-obra nov. & 10,82 & $-0,44$ & $\infty$ \\
Venda mão-de-obra dez. & 11,13 & $-0,40$ & $\infty$ \\
Venda mão-de-obra jan. & 11,32 & 9,24 & $\infty$ \\
Venda mão-de-obra fev. & 11,29 & $-0,29$ & $\infty$ \\
Venda mão-de-obra mar. & 11,34 & $-0,23$ & $\infty$ \\
Venda mão-de-obra abr. & 11,36 & $-0,17$ & $\infty$ \\
Venda mão-de-obra mai. & 11,55 & $-0,06$ & $\infty$ \\
Venda mão-de-obra jun. & 11,51 & $-0,06$ & $\infty$ \\
Venda mão-de-obra jul. & 11,36 & 0 & $\infty$ \\
\hline
\end{tabular}

Fonte: Dados da pesquisa

\subsubsection{Modelo com incorporação do risco (MOTAD) para a propriedade tipo I}

Nas Tabelas 16 e 17 apresentam-se os valores de margens brutas e desvios, assim como a combinação das principais atividades correspondente a cada um dos níveis analisados no MOTAD, respectivamente para os casos com e sem venda de mão-deobra. Os valores de margens brutas e desvios parametrizados permitem traçar as fronteiras eficientes, para as mesmas situações.

Observa-se que para os níveis mais altos de margem bruta e risco, a proporção milho/soja é maior no caso em que não se dá venda de mão-de-obra. Neste caso, diminui 
a área de soja e aumentam as de milho e feijão. O uso de crédito para soja está previsto em todos os níveis de margem bruta/risco, em ambas situações analisadas.

O milho ultrapassa as áreas de soja nos níveis intermediários e baixos de margem bruta/risco, na situação em que ocorre a venda de mão-de-obra, fato que também ocorre quando a mão-de-obra não é vendida, nos níveis mais baixos de margem bruta/risco.

Reduzem-se as áreas cultivadas com todas as culturas à medida que aumenta a aversão ao risco, com exceção do feijão no caso em que não se vende mão-de-obra, onde ela permanece constante ao longo de toda fronteira. A área cultivada com feijão, neste caso é sempre superior à prevista na situação em que ocorre emprego externo da mãode-obra familiar.

No modelo MOTAD prioriza-se a venda de mão-de-obra (na situação em que ela é prevista), em relação a todas as demais atividades que compõem o sistema de produção atual, considerando o padrão tecnológico adotado pelo produtor. Apenas no nível máximo de margem bruta/risco os quatro alqueires de terra são usados integralmente.

O sistema de produção atual, pelo que se pode observar nas Tabelas 16 e 17, está mais próximo, pela composição das culturas, à solução do modelo de maximização da margem bruta com venda de mão-de-obra. Entretanto, o agricultor não tem conseguido empregar integralmente sua mão-de-obra fora da propriedade, conforme era sua previsão, incorporada ao modelo. Assim, a estratégia de liberar mão-de-obra para trabalho externo tem-lhe propiciado uma renda muito inferior à obtida no problema de maximização dos retornos, mas com desvios ainda superiores aos previstos quando da parametrização da margem bruta máxima, no MOTAD. O fato de não contar com dados sobre a oferta regional de empregos para absorver a mão-de-obra excedente não permitiu a especificação adequada do modelo neste aspecto. 
Tabela 16. Resultados do modelo MOTAD para a propriedade tipo I, com venda de mão-de-obra.*

\begin{tabular}{c|c|c|c|c|c|c|c}
\hline $\begin{array}{c}\text { Margem } \\
\text { Bruta } \\
\text { (R\$) }\end{array}$ & Desvio & $\begin{array}{c}\text { Soja } \\
\text { (alq) }\end{array}$ & $\begin{array}{c}\text { Milho } \\
\text { (alq) }\end{array}$ & $\begin{array}{c}\text { Feijão } \\
\text { (alq) }\end{array}$ & $\begin{array}{c}\text { Erva Mate } \\
\text { (alq) } \\
(1)\end{array}$ & $\begin{array}{c}\text { Crédito } \\
\text { para } \\
\text { Soja (alq) }\end{array}$ & $\begin{array}{c}\text { Venda } \\
\text { MDO } \\
(2)\end{array}$ \\
\hline $4630^{* *}$ & 4947 & 2,63 & 0,65 & 0,09 & 0 & 2,63 & 260,00 \\
4130 & 3375 & 1,75 & 0,65 & 0,09 & 0,25 & 1,75 & 260,00 \\
3630 & 2094 & 1,03 & 0,65 & 0,09 & 0,25 & 1,03 & 258,87 \\
3130 & 973 & 0,36 & 0,61 & 0,09 & 0,25 & 0,36 & 260,00 \\
2630 & 308 & 0,06 & 0,42 & 0,09 & 0,00 & 0,06 & 256,11 \\
2130 & 228 & 0,05 & 0,38 & 0,05 & 0,00 & 0,05 & 224,42 \\
1630 & 177 & 0,06 & 0,35 & 0,04 & 0,00 & 0,06 & 183,81 \\
1130 & 131 & 0,04 & 0,28 & 0,03 & 0,00 & 0,04 & 148,91 \\
630 & 90 & 0,04 & 0,21 & 0,03 & 0,00 & 0,04 & 110,59 \\
130 & 54 & 0,02 & 0,13 & 0,02 & 0,00 & 0,02 & 75,97 \\
0 & 46 & 0,02 & 0,12 & 0,02 & 0,00 & 0,02 & 66,47 \\
$1754 * * *$ & 6457 & 3,225 & 0,125 & 0,025 & 0,25 & 3,225 & 24,00 \\
\hline
\end{tabular}

Fonte: Dados da pesquisa

* As áreas de mata, quintal doméstico e erva mate foram definidas através de restrições: mata $\geq 0,5$ alq; quintal $\leq 0,125$ alq (inclui produção de hortaliças, frutas e aves) e erva mate $\leq 0,25$ alq.

** Solução dada pela PL

*** Sistema de produção atual

(1) considerando o limite máximo de 0,25 alq

(2) considerando o limite máximo para venda de mão-de-obra equivalente a 21,67 DH mensais

Tabela 17. Resultados do modelo MOTAD para a propriedade tipo I, sem venda de mãode-obra*

\begin{tabular}{c|c|c|c|c|c|c}
\hline $\begin{array}{c}\text { Margem } \\
\text { Bruta } \\
(\mathrm{R} \$)\end{array}$ & Desvio & $\begin{array}{c}\text { Soja } \\
\text { (alq) }\end{array}$ & $\begin{array}{c}\text { Milho } \\
\text { (alq) }\end{array}$ & $\begin{array}{c}\text { Feijão } \\
\text { (alq) }\end{array}$ & $\begin{array}{c}\text { Erva Mate } \\
\text { (alq) } \\
(1)\end{array}$ & $\begin{array}{c}\text { Crédito para } \\
\text { Soja (alq) }\end{array}$ \\
\hline $1841^{* *}$ & 5241 & 1,85 & 1,33 & 0,18 & 0,02 & 1,85 \\
1541 & 4397 & 1,48 & 1,12 & 0,18 & 0,25 & 1,48 \\
1241 & 3705 & 1,23 & 0,94 & 0,18 & 0,25 & 1,23 \\
941 & 3013 & 0,97 & 0,76 & 0,18 & 0,25 & 0,97 \\
641 & 2321 & 0,72 & 0,58 & 0,18 & 0,25 & 0,72 \\
341 & 1630 & 0,47 & 0,40 & 0,18 & 0,25 & 0,47 \\
41 & 968 & 0,20 & 0,24 & 0,18 & 0,25 & 0,20 \\
0 & 888 & 0,15 & 0,24 & 0,18 & 0,25 & 0,15 \\
$1491^{* * *}$ & 6360 & 3,225 & 0,125 & 0,025 & 0,25 & 3,225 \\
\hline
\end{tabular}

Fonte: Dados da pesquisa

* As áreas de mata, quintal doméstico e erva mate foram definidas através de restrições: mata $\geq 0,5$ alq; quintal $\leq 0,125$ alq (inclui produção de hortaliças, frutas e aves) e erva mate $\leq 0,25$ alq.

** Solução dada pela PL

*** Sistema de produção atual, não se considerando os valores referentes à venda de 24 jornadas de trabalho. 


\subsubsection{Localização do sistema atual na fronteira eficiente e coeficiente de aversão ao risco da propriedade tipo I}

Conforme se pode visualizar nas Figuras 5 e 6 , o sistema atual do produtor do tipo I também se localiza abaixo da curva de fronteira eficiente, o que significa que não está alcançando eficiência máxima na produção no que diz respeito à relação entre risco e margem bruta esperada. Da mesma forma que no caso anterior, o seu mix de atividades não conduz à maior eficiência possível. Em ambas situações analisadas para a propriedade tipo I (com e sem venda de mão-de-obra), a soma dos desvios negativos do sistema atual é superior à estabelecida pelo MOTAD, quando da minimização dos desvios negativos em relação à margem bruta máxima. Isto equivale a dizer que o agricultor assume grandes níveis de risco, proporcionalmente às margens brutas que vem obtendo.

O ponto da fronteira que apresenta a menor distância ao ponto representativo do sistema atual da propriedade tipo I também se encontra entre os dois níveis mais altos de margem bruta/risco. As linhas tracejadads nas figuras correspondem à menor distância considerada do sistema atual até a fronteira eficiente. O coeficiente de aversão ao risco deste produtor, que corresponde à inclinação da curva nesse ponto, é de 0,3181 na situação em que ocorre a venda de mão-de-obra e de 0,3555 quando tal venda não se efetiva.

Peres (1976), estudando propriedades agrícolas da região de Ribeirão Preto - SP, encontrou coeficientes de aversão ao risco de 0,8188 para pequenas empresas e de 0,0439 para as empresas de maior porte. Para o autor, estes resultados dão uma idéia da diferente disposição dos dois tipos de empresas para suportarem o risco, concluindo que, conforme esperado, as pequenas empresas foram mais aversas ao risco que as grandes.

Contrariamente ao que era de se esperar, os resultados obtidos nesta dissertação mostraram que o pequeno produtor apresentou-se menos averso ao risco que o grande. 
Este fato deve estar ocorrendo como fruto da estratégia produtiva adotada pelo produtor, que o distancia, em termos comportamentais, dos pequenos produtores principalmente voltados para o autoconsumo.

A distância do ponto representativo do sistema atual à fronteira pode ser um indício do grau de estabilidade do sistema. Na situação em que se previu a venda de mão-de-obra, tal distância é grande, o sistema se mostra instável: a tendência seria que o produtor buscasse, na fronteira, o ponto que lhe gerasse a mesma renda, com menos risco. Este seria o ponto "A", onde a área de soja seria extinta na prática (estaria entre 0,05 e 0,06 alq, o que inviabiliza o sistema de plantio direto motomecanizado) e as áreas de milho e feijão seriam reduzidas à perto da metade do previsto quando da maximização da margem bruta no modelo determinista: a área de milho ficaria entre 0,35 e 0,38 alq e a de feijão, entre 0,04 e 0,05 (para ambas culturas, áreas pouco maiores que o que se produz hoje, para autoconsumo). A maior parte da renda adviria da venda de mão-de-obra, que estaria variando entre 183 e 224 DH. Esta situação estaria refletindo a carência de opções produtivas para este tipo de agricultor na área de estudos, dada sua escassez de recursos.

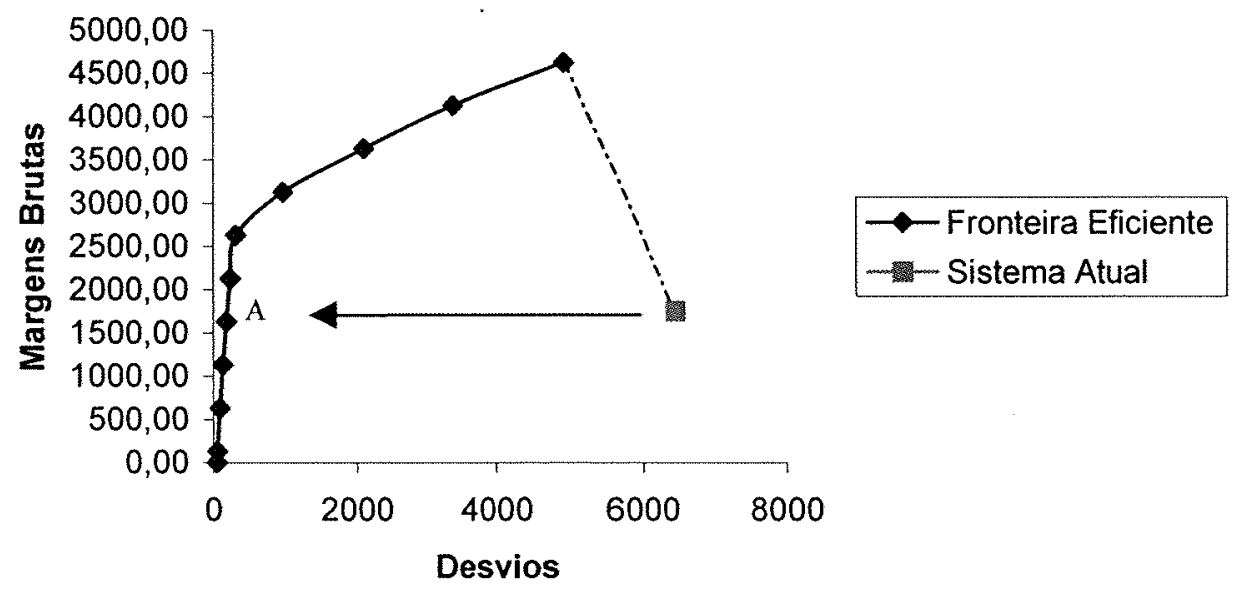

Figura 5 - Fronteira eficiente da propriedade tipo I, com venda de mão-de-obra. 


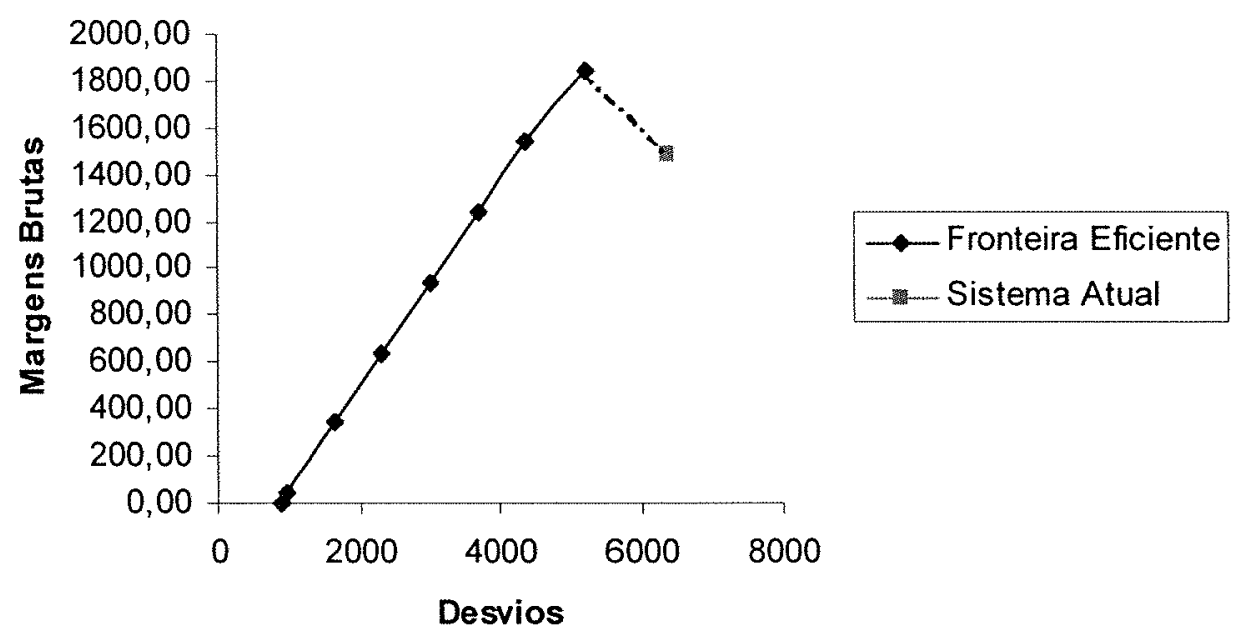

Figura 6 - Fronteira eficiente da propriedade tipo I, sem venda de mão-de-obra.

\subsubsection{Diversificação de atividades como forma de redução do risco para a propriedade tipo I}

A matriz de correlações entre as atividades (Tabela 18) mostra que a venda de mão-de-obra, em todos os meses do ano, apresentou correlações negativas e altas com as demais atividades produtivas da propriedade (renda do feijão, renda do milho, renda da soja e renda da erva mate), com exceção das correlações entre venda de mão-de-obra em fevereiro e renda do feijão, e, venda de mão-de-obra em maio e renda da erva-mate. Este fato estaria mostrando a vantagem de se combinar a venda de mão-de-obra às atividades de produção agrícola praticadas na propriedade. Por outro lado, as correlações entre as mencionadas atividades agrícolas implementadas na propriedade apresentaram, em sua maioria, valores positivos e altos, o que não estaria mostrando vantagens explícitas na diversificação de culturas como forma de redução dos riscos, tendo em vista o atual sistema de produção praticado por este produtor. 


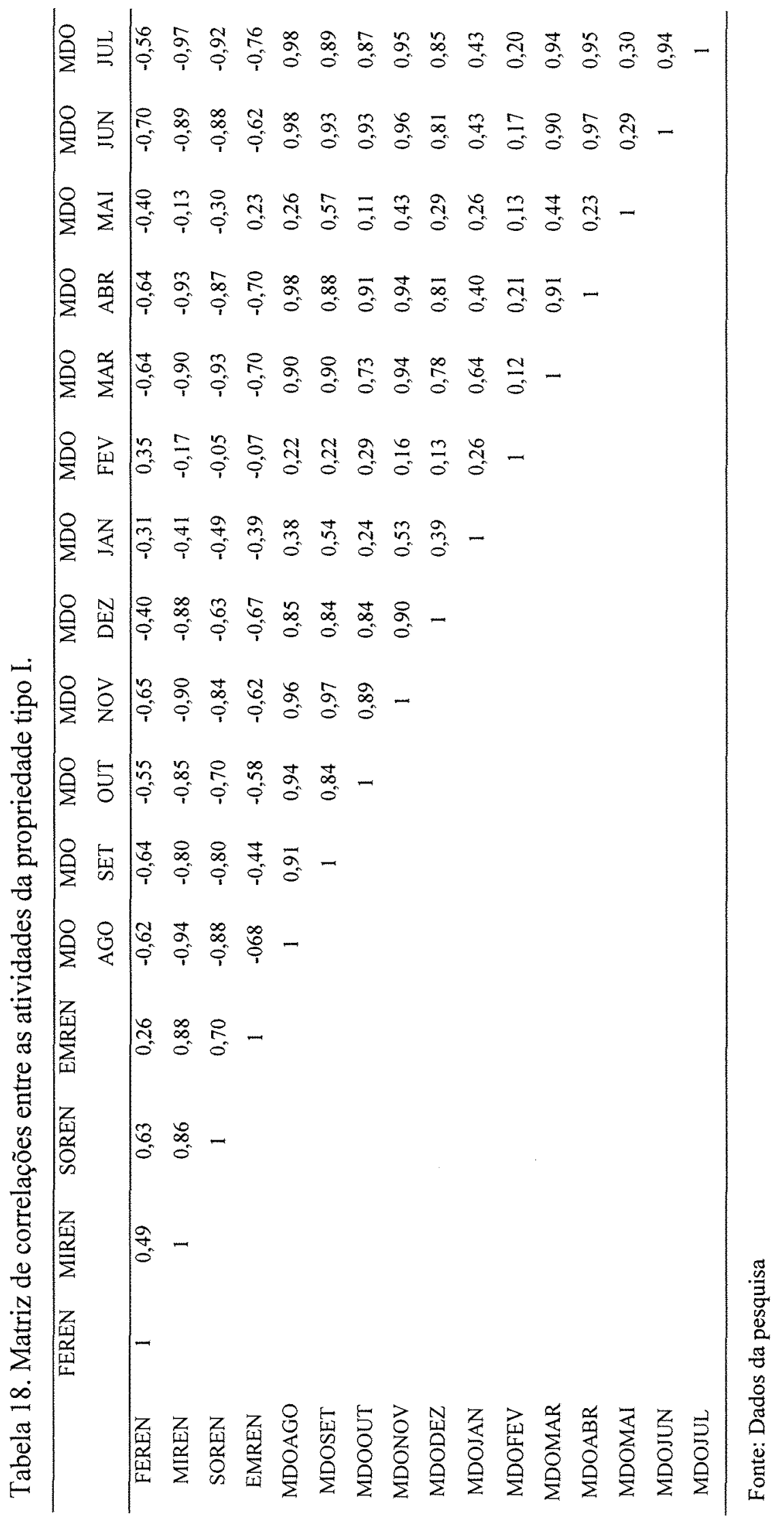




\section{CONCLUSÕES}

A tipificação de produtores, realizada com base na amostra de 34 estabelecimentos agrícolas usando a análise fatorial por componentes principais, foi validada tanto por agricultores como por técnicos locais. Ela permitiu a identificação e descrição de quatro grupos de estabelecimentos na área de estudos, embasando a escolha das propriedades para análise do seu comportamento em relação a retornos e riscos. Os modelos dos sistemas atuais foram construídos considerando-se o padrão tecnológico adotado por cada produtor para o mix de atividades produtivas implementado na safra agrícola 2000/2001.

Com o modelo MOTAD, conseguiu-se simular de melhor forma a combinação de atividades do sistema atual da propriedade tipo IV (grande produtor, com uso de mãode-obra predominantemente familiar), comparativamente ao modelo tradicional de PL. A inclusão do risco, nesse caso, permitiu uma solução mais próxima ao comportamento observado do produtor que aquela fornecida pelo modelo de maximização das margens brutas. Este sistema produtivo estaria mais próximo da estabilidade, fato que pode ser observado pela menor distância que o separa da fronteira eficiente.

Os produtores desse grupo têm um comportamento que os aproxima ao conceito de empresários rurais quando se analisam o processo de produção e os altos rendimentos obtidos com a cultura da soja e milho, com as quais se busca a maximização das receitas. Entretanto, mantêm-se ligados à agricultura tradicional através da diversificação e produção para autoconsumo, como estratégia para redução de risco. A renda advinda da agropecuária neste grupo, conforme se pode constatar nas entrevistas, 
tem permitido a capitalização da propriedade, traduzida na ampliação do seu tamanho, da maquinaria e do rebanho bovino.

Para este tipo de agricultor, a intensificação da produção animal, aproveitando os grãos produzidos para arraçoamento, poderia agregar valor à produção e aumentar a renda da propriedade. Entretanto, a situação precária das estradas rurais na região limita investimentos em atividades que exijam acesso contínuo à propriedade para abastecimento de insumos e escoamento da produção, como por exemplo, a atividade leiteira (que se mantém atualmente com um baixo nível de produtividade), ou a suinocultura, que os produtores teriam interesse em implementar. Adicionalmente, a intensificação dessas atividades implicaria na necessidade de mão-de-obra externa (no sistema atual, a mão-de-obra familiar já é restrição atuante ou está próxima a sê-lo, em algumas épocas do ano). Os produtores demonstraram-se aversos à contratação de mãode-obra permanente, tanto pelo receio do aumento dos custos de produção como de possíveis implicações trabalhistas.

A propriedade do tipo I analisada, enquadrada no grupo dos pequenos produtores de menores recursos, foi escolhida pelo interesse que desperta a análise da cultura da soja em pequenas propriedades. Segundo dados do IBGE (Censo Agropecuário 1995/96), mais de 46\% das propriedades que produzem soja no Paraná o fazem em áreas inferiores a 20 ha e em cerca de $20 \%$, essa área é inferior a 10 ha. Embora na área de estudos os dados do censo indiquem que o cultivo da soja se faça predominantemente em estratos de área superiores a $20 \mathrm{ha}$, os produtores e técnicos locais observam uma tendência nos últimos anos à introdução da soja em estabelecimentos muito pequenos, devido à possibilidade de contratação de serviço de máquinas e à diminuição na rentabilidade de culturas como milho e feijão. Esta estratégia seria praticada especialmente por jovens agricultores, na busca das melhores combinações de alternativas produtivas para potencializar seus recursos. Esse processo de experimentação acontece até que se determine uma relação retorno/risco considerada conveniente. No produtor do tipo I, a grande distância entre o ponto representativo do 
sistema atual e o ponto da fronteira que minimiza a distância até ele seria um reflexo dessa situação de instabilidade, quando se prevê a venda de mão-de-obra.

O pequeno produtor em estudo assume uma estratégia que prioriza a cultura da soja e a venda de mão-de-obra. Ele diversifica menos que o grande, e se localiza mais próximo à situação de maximização da margem bruta prevista nos modelos deterministas, no que diz respeito à área destinada à cultura da soja. Entretanto, ele consegue rendas inferiores e incorre em risco superior ao previsto pelo MOTAD quando este minimiza os desvios na solução de máximo retorno dada pela PL. O modelo MOTAD prioriza a venda de mão-de-obra (na situação em que ela é prevista), em relação a todas as demais atividades que compõem o sistema de produção atual, considerando o padrão tecnológico adotado pelo produtor. Apenas no nível máximo de margem bruta/risco os quatro alqueires de terra são usados integralmente.

Assim, contrariamente ao que era de se esperar, o pequeno produtor do tipo I apresentou coeficiente de aversão ao risco menor que o do grande. Ele difere dos sistemas de produção adotados pela maioria dos produtores de seu porte na região principalmente voltados à produção de subsistência - onde os riscos são basicamente devidos a variações nas produtividades das culturas. Ao se vincular estreitamente ao mercado, através da cultura da soja e da venda de mão-de-obra, esta pequena propriedade soma aos riscos inerentes a variações climáticas, aqueles referentes a variações nos preços. Por outro lado, ao não conseguir empregar de forma plena a sua mão-de-obra conforme havia planejado, o produtor não alcança as receitas totais previstas no modelo de maximização da margem bruta com venda de mão-de-obra. Por estar imerso no processo de "experimentação", o produtor pode ainda não ter consciência do risco em que incorre e que fragiliza seu sistema de produção.

O caminho "natural" resultante do processo de experimentação deste produtor seria o seu deslocamento à esquerda de sua localização atual, até atingir o ponto na fronteira onde obtenha a mesma (baixa) renda, mas alcance níveis muito inferiores de 
risco. Mesmo nesse ponto, a maior parte da renda adviria da venda de mão-de-obra, o que dependeria da existência de um mercado local para absorvê-la.

Por outro lado, com uma política de geração de empregos rurais e urbanos na região, o produtor poderia empregar integralmente a sua própria mão-de-obra e implementar a agricultura em tempo parcial. Neste caso, na propriedade, seria de interesse a melhoria do subsistema autoconsumo (por exemplo, inclusão de leite e suínos com essa finalidade) e/ou a implementação de atividades que pudessem também gerar renda, ocupando principalmente a mão-de-obra dos demais membros da família. Linhas de crédito e assistência técnica seriam necessárias para melhorar a produção, já que atualmente, com exceção da soja, as atividades produtivas são conduzidas de forma bastante rudimentar.

Uma terceira possibilidade a se considerar seria a manutenção de toda a mão-deobra familiar na propriedade. Para isso, seria necessária a introdução de novas alternativas produtivas intensivas nesse fator e com capacidade de geração de renda. Aqui, seria exigido um suporte do Estado em termos de formação e capacitação, crédito, assistência técnica e melhoria da infraestrutura regional para transporte e comercialização da produção. Mesmo assim, o tamanho da propriedade deveria continuar se constituindo num fator limitante.

Outro cenário possível seria que, dadas as condições atuais altamente restritivas, o produtor se visse obrigado a vender sua propriedade, levando a permanência na área apenas dos sistemas de produção mais eficientes. Aqui, cabe avaliar o custo social que significa a saída dos pequenos produtores, engrossando a demanda por fontes de trabalho urbanas. Convém salientar, ademais, que nos modelos trabalhados estão previstas saídas de caixa referentes ao consumo alimentar da família. Ou seja, apesar das margens brutas finais serem baixas, uma alimentação equilibrada estaria garantida (em boa parte graças à produção da propriedade), o que seria um fator a considerar na decisão de se incentivar a permanência dos agricultores no meio rural. 
O MOTAD pode ser utilizado na simulação, análise e avaliação dos cenários apresentados, havendo a necessidade de um esforço interdisciplinar para a definição de bons coeficientes técnicos, referentes tanto a alternativas de produção como informações de mercado de produtos alternativos e mão-de-obra, para alimentar tais modelos. Pode tratar-se, portanto, de uma ferramenta útil tanto na análise técnica/econômica dos sistemas de produção como na definição de políticas de desenvolvimento.

Para a agricultura familiar, de forma geral, a questão da sucessão e permanência dos filhos nas unidades de produção se constitui num problema a ser enfrentado, mesmo pelas propriedades de maior porte, quando as famílias são numerosas. Daí ser fundamental o investimento na educação dos filhos, potencializando-os tanto para assumir e melhorar os atuais sistemas de produção como para ingressar em outros mercados de trabalho. Lembramos aqui, Schultz, citado em diversos pontos deste trabalho, que considerava ser a capacidade do pessoal ligado à agricultura o principal fator para explicar as diferenças entre os países no sucesso do setor agrícola em contribuir para o desenvolvimento econômico.

A decisão pelos caminhos a seguir passa pelos interesses e aspirações dos produtores e suas famílias e pelas condições dadas através de políticas agrícolas e outros incentivos (emprego, educação para os filhos, saúde, lazer, etc) para que sua permanência nas propriedades se efetive.

Finalmente, ressalta-se que uma limitação deste trabalho é não contar com dados para a melhor quantificação da oferta e demanda de trabalho para mão-de-obra volante na região, fato que dificultou uma melhor especificação dos modelos, especialmente no caso do pequeno produtor.

Seria interessante, por outro lado, estender a análise para os demais tipos de sistemas de produção, para se ter uma visão mais abrangente da agricultura e melhor embasar ações de desenvolvimento regional. 


\section{REFERÊNCIAS BIBLIOGRÁFICAS}

ALVES, E.; LOPES, M.; CONTINI, E. O empobrecimento da agricultura brasileira. Revista de Política Agrícola, v.8, n.3, p.5-19, 1999.

ARAÚJO, L.A. Fronteira de eficiência econômica sob condições de risco: uma análise da convergência econômica entre empresas do sul de Santa Catarina. Piracicaba, 1997. 150p. Dissertação (Mestrado) - Escola Superior de Agricultura "Luiz de Queiroz", Universidade de São Paulo.

AZEVEDO FILHO, A.J.B.V.; PERES, F.C. Competitividade da cultura da soja em uma empresa da região de Campinas, SP. In: CONTINI, E.; ARAÚJO, J.D.; OLIVEIRA, A.J. et al. Planejamento da propriedade agrícola: modelos de decisão. Brasília: EMBRAPA, DDT, 1984. p.289-300.

BADER, G.E.; ROSSI, A.R. Focus groups: a step by step guide, 1999. 39p.

BALVERDE, N.R.M. Avaliação econômica de sistemas intensivos na pecuária uruguaia em condições de risco: um estudo de caso. Piracicaba, 1997. 83p. Dissertação (Mestrado) - Escola Superior de Agricultura "Luiz de Queiroz", Universidade de São Paulo.

BAUER, P.W. Recent developments in the econometric estimation of frontiers. Journal of Econometrics, v.46, n.1/2, p.39-56, Oct./Nov. 1990. 
BERDEGUÉ, J.A.; LARRAÍN, B. Como trabajan los campesinos: una propuesta metodológica. Santiago: Academia de Humanismo Cristiano, Grupo de Investigaciones Agrarias, 1987.63p. (Cuadernillo de información agraria, 18)

BERDEGUÉ, J.A.; SOTOMAYOR, O.; ZILLERUELO, C. Metodología de tipificación y clasificación de sistemas de producción campesinos de la Provincia de Nuble, Chile. In: ESCOBAR, G.; BERDEGUÉ, J. (Ed.). Tipificación de sistemas de producción agrícola. Santiago: Red Internacional de Metodología de Investigación en Sistemas de Producción, 1990. p.85-117.

BIALOSKORSKI NETO, S.; LORENA NETO, B.; PEREIRA, L. Módulo de subsistência na pequena agricultura. Campinas: Coordenadoria de Assistência Técnica Integral - CATI, 1988. 28p. (Documento técnico, 71)

BITTENCOURT, G.A.; BIANCHINI, V. Estudo de sistemas agrários: Pitanga/Boa Ventura. Curitiba, 1997. 94p. (FAO/NCRA Projeto UTF/BRA/036/BRA)

BITTENCOURT, M.V.L.; SAMPAIO, A.V.; HASEGAWA, M.M. Tomada de decisão em condições de risco: aplicação para a região norte do Paraná. In: CONGRESSO BRASILEIRO DE ECONOMIA E SOCIOLOGIA RURAL, 36., Poços de Caldas, 1998. Anais. Brasília: SOBER, 1998. p.987-998.

CAIXETA FILHO, J.V. Pesquisa operacional aplicada. Piracicaba: ESALQ, Depto Economia, Administração e Sociologia/USP, 1998. 183p. (Relatório técnico referente a projeto de pesquisa apoiado pelo CNPq. Proc.: 301540/91-8-NV)

CARLINI-COTRIM, B. Potencialidades da técnica qualitativa grupo focal em investigações sobre abuso de substâncias. Saúde Pública, v.30, n.3, p.285-293, 1996. 
CONCEIÇÃO, J.C.P.R. Fronteira de produção estocástica e eficiência técnica na agricultura. Piracicaba, 1998. 108p. Tese (Doutorado) - Escola Superior de Agricultura "Luiz de Queiroz", Universidade de São Paulo.

CONTINI, E; ARAÚJO, J.D.; GARRIDO, W.E. Instrumental econômico para a decisão na propriedade agrícola. In: CONTINI, E.; ARAÚJO, J.D.; OLIVEIRA, A.J. et al. Planejamento da propriedade agrícola: modelos de decisão. Brasília: EMBRAPA, DDT, 1984. p.7-22.

CRUZ, E.R. Aspectos teóricos sobre incorporação de riscos em modelos de decisão. In: CONTINI, E.; ARAÚJO, J.D.; OLIVEIRA, A.J. et al. Planejamento da propriedade agrícola: modelos de decisão. Brasília: EMBRAPA, DDT, 1984. p.237-259.

DOSSA, D. Programação linear na gestão da propriedade rural: um enfoque alternativo. Teoria e Evidência Econômica, v.2, n.4, p.33-60, nov.1994.

DUFUMIER, M. Importancia de la tipología de unidades de producción agrícolas en el análisis de diagnóstico de realidades agrarias. In: ESCOBAR, G.; BERDEGUÉ, J. (Ed.). Tipificación de sistemas de producción agrícola. Santiago: Red Internacional de Metodología de Investigación en Sistemas de Producción, 1990. p.63-81.

ESCOBAR, G.; BERDEGUÉ, J. Conceptos y metodología para la tipificación de sistemas de finca: la experiencia de RIMISP. In: ESCOBAR, G.; BERDEGUÉ, J. (Ed.). Tipificación de sistemas de producción agrícola. Santiago: Red Internacional de Metodología de Investigación en Sistemas de Producción, 1990. p.13-43. 
FIGUEIREDO, N.M.S.; BACCHI, M.R.P.; PERES, F.C. Alternativas para a produção agrícola do projeto de assentamento rural Araras 2. In: ENCONTRO ANUAL DA ASSOCIAÇÃO NACIONAL DOS PROGRAMAS DE PÓS-GRADUAÇÃO EM ADMINISTRAÇÃO, 17., Salvador, 1993. Anais. Florianópolis: ANPAD, 1993. v.5, p.109-121.

FORSUND, F.R.; LOVELL, K.C.A.; SCHMIDT, P. A survey of frontier production functions and their relationship to efficiency measurement. Journal of Econometrics, v.13, n.1, p.5-25, May 1980.

FUNDAÇÃO INSTITUTO BRASILEIRO DE GEOGRAFIA E ESTATÍSTICA. Censo agropecuário 1995/96. Rio de Janeiro: IBGE, 1997. n.20.

GONÇALVES, J.S.; SOUZA, S.A.M. Heterogeneidade e competitividade: o signifícado do conceito frente ao mosaico de disparidades da agricultura brasileira. Informações Econômicas, v.30, n.11, p.34-50, nov. 2000.

GONÇALVES, J.S.; SOUZA, S.A.M. Agronegócio no Vale do Ribeira: caracterização da realidade e proposta de intervenção numa região carente. Informações Econômicas, v.31, n.1, p.39-49, jan.2001.

GUANZIROLI, C.E. (Coord); CARDIM, S.E.C.S.; ROMEIRO, A.R. et al. Novo retrato da agricultura familiar: o Brasil redescoberto. Brasília, fev. 2000. (Projeto de Cooperação Técnica INCRA/FAO). http://www.incra.gov.br/fao/default.htm (23 maio 2002) 
GUERREIRO, E. (Coord.); BENASSI, D.A.; AHRENS, D.C. et al. Projeto Itaiacoca: plano integrado de ações para o desenvolvimento sustentável de sistemas de produção no município de Ponta Grossa-Paraná. Ponta Grossa: Instituto Agronômico do Paraná/Prefeitura Municipal de Ponta Grossa/EMATER-PR, 1995. $143 p$.

HAZELL, P.B.R. A linear alternative to quadratic and semi-variance programing for farmer planning under uncertainty. American Journal of Agricultural Economics, v.53, n.1, p.53-62, Feb. 1971.

KNIGHT, F. H. Risk, uncertainty and profit. Boston: Houghton-Miffilin, 1921.

LAMBERT, D.K.; SHONKWILER, J.S. Factor bias stochastic technical change. American Journal of Agricultural Economics, v.77, n.3, p.578-590, Aug.1995.

MAN YU, C.; SEREIA, V.J. Tipificação e caracterização dos produtores rurais do Estado do Paraná - 1980. Londrina: IAPAR, maio 1993. (Boletim técnico, 39)

MARKOWITZ, H. Portfolio selection. Journal of Finance, v.7, n.1, p.77-91, Mar. 1952.

MIALHE, L.G. Manual de mecanização agrícola. São Paulo: Ed. Agronômica Ceres, 1974. 301p.

MONARDES, A.; COX, T.; NAREA, D.; LAVAL, E.; REVOREDO, C. Evaluación de adopción de tecnología. Santiago: CEDRA, 1993. 151p.

PEREIRA, J.C.R. Análise de dados qualitativos: estratégias metodológicas para as ciências da saúde, humanas e sociais. 2.ed. São Paulo: Editora da Universidade de São Paulo, 1999. 156p. 
PEREIRA FILHO, C.A. Eficiência econômica da pequena produção familiar agrícola no recôncavo do estado da Bahia: uma análise não paramétrica de fronteiras de produção multi-produto. Piracicaba, 2000. 121p. Tese (Doutorado) - Escola Superior de Agricultura "Luiz de Queiroz", Universidade de São Paulo.

PERES, A.R.P. Baixa produtividade do milho como conseqüência da tomada de decisão sob condições de risco na agricultura. Piracicaba, 1981. 118p. Dissertação (Mestrado) - Escola Superior de Agricultura "Luiz de Queiroz", Universidade de São Paulo.

PERES, F.C. Derived demand for credit under conditions of risk. Ohio, 1976. 141p. Dissertation (Ph.D.) - The Ohio State University.

PORTUGAL, A.D. A importância estratégica da prospecção tecnológica para o SNPA. In: CASTRO, A.M.G.; LIMA, S.M.V.; GOEDERT, W.J. et al. (Ed.). Cadeias produtivas e sistemas naturais: prospecção tecnológica. Brasília: EMBRAPA, SPI/DPD, 1998. cap.1, p.9-20.

QUIRINO, T.R. Impacto agroambiental e agenda da pesquisa agropecuária brasileira. In: CASTRO, A.M.G.; LIMA, S.M.V.; GOEDERT, W.J. et al. (Ed.). Cadeias produtivas e sistemas naturais: prospecção tecnológica. Brasília: EMBRAPA, SPI/DPD, 1998. cap.3, p.61-74.

SABBAG, W.J. Modernização agrícola em Pernambuco, 1950-1996. Piracicaba, 2000. 170p. Tese (Doutorado) - Escola Superior de Agricultura "Luiz de Queiroz", Universidade de São Paulo.

SANTOS, A.C. Utilização da programação linear na determinação da combinação que maximize a renda na empresa rural. Caderno de Administração Rural, v.2, n.2, p.109-125, jul./dez.1990. 
SHARMA, S. Applied multivariate techniques. New York: John Wiley \& Sons, 1996. 493p.

SCHULTZ, T. A transformação da agricultura tradicional. Rio de Janeiro: Zahar Editores, 1965.207p.

TORESON, L.; LANZER, E.A. Avaliação da eficiência relativa das propriedades agrícolas típicas de Santa Catarina. In: CONGRESSO BRASILEIRO DE ECONOMIA E SOCIOLOGIA RURAL, 33., Curitiba, 1995. Anais. Brasília: SOBER, 1995. v.1, p.559-565.

TUPICH, C.M.A. A eficiência técnica da produção civil entre a região Sul e as outras regiões do Brasil no ano de 1990: uma análise comparativa. Curitiba, 1996. 136p. Dissertação (Mestrado) - Universidade Federal do Paraná.

WELCH, F. Education in production. Journal of Political Economy, v.78, n.1, p.35-39, 1970. 